\title{
32. GEOCHEMISTRY AND PETROGRAPHY OF ORGANIC MATTER IN SEDIMENTS FROM DEEP SEA DRILLING PROJECT SITES 545 AND 547, MAZAGAN ESCARPMENT ${ }^{1}$
}

\author{
Jürgen Rullkötter, Prasanta K. Mukhopadhyay, Rainer G. Schaefer, and Dietrich H. Welte, Institute of Petroleum \\ and Organic Geochemistry, Jülich ${ }^{2}$
}

\begin{abstract}
A series of sediment samples of probable Triassic to Miocene age from DSDP Sites 545 and 547 seaward of the Mazagan Plateau on the Northwest African Continental Margin off Morocco were investigated by organic geochemical methods including organic carbon determination, Rock-Eval pyrolysis, gas chromatography and combined gas chromatography/mass spectrometry (GC/MS) of extractable hydrocarbons, and kerogen microscopy. The total organic matter content and the organofacies types are significantly variable, but a generally strong influence of terrigenous organic matter was found in all sediments. The organic matter preservation at Sites 545 and 547 was controlled by the intensity of the terrigenous organic matter supply from the nearby continent, which appeared to be particularly strong during the Cretaceous and had diminished at least by early Miocene times. A noticeable amount of marine organic matter has been preserved in the deep-water sediments by a sequence of processes starting with primary deposition in oxygen-depleted shallow waters on the outer shelf followed by downslope transport and rapid burial at the continental rise. These mass movements happened in the Eocene and throughout the Cretaceous as far as this process could be traced by the sedimentary record. Thin black shale layers in the Jurassic interval at Site 547 indicate strongly fluctuating organic matter preservation conditions probably also controlled by the intensity of terrigenous organic matter supply. All of the primary organic matter except that in the Triassic sediment was thermally immature as expressed by low vitrinite reflectance values and an abundance of olefins in the extractable hydrocarbons.
\end{abstract}

\section{INTRODUCTION}

The geochemistry and petrography of organic matter in Northwest African continental margin sediments have been studied in the past on a large number of samples from various deep holes drilled during DSDP Leg 41 (Site 367, Cape Verde Basin; Site 368, Cape Verde Rise; Site 369, off Cape Bojador; Site 370, Moroccan Basin); Leg 47A (Site 397, off Cape Bojador); and Leg 50 (Site 415, Agadir Canyon; Site 416, Moroccan Basin). A recent synthesis (Rullkötter, Cornford, et al., 1982) of the results concluded that the quantity and provenance of the organic matter as well as the depositional environment varied considerably with geological time and geographic location along the Northwest African continental margin, so that a number of organofacies types could be differentiated. During DSDP Leg 79, additional deep holes were drilled at Sites 545 and 547 seaward of the Mazagan Plateau, about $150 \mathrm{~km}$ west of Casablanca (Fig. 1). The sedimentary sequences penetrated extend to the oldest sediments recovered so far from the deep Atlantic Ocean. These sediments offer another excellent opportunity to study the deposition of organic matter on the Northwest African continental margin since the early phase of the opening of the Atlantic Ocean.

Figure 2 illustrates the geological setting of Sites 545 and 547 that were projected onto a northwest-southeast seismic line $\left(A-A^{1}\right)$ through the rectangle shown in Figure 1. Site 545 is located near the foot of the steep

\footnotetext{
${ }^{1}$ Hinz, K., Winterer, E. L., et al., Init. Repts. DSDP, Washington (U.S. Govt. Printing Office).

2 Institute of Petroleum and Organic Geochemistry (ICH-5), KFA Jülich GmbH, P.O. Box 1913, D-5170 Jülich 1, Federal Republic of Germany.
}

Mazagan Escarpment in $3150 \mathrm{~m}$ water depth. Drilling was terminated in calcareous Middle to Late Jurassic sediments at $701 \mathrm{~m}$ depth after penetrating a Neogene and an incomplete Cretaceous section (Aptian-Cenomanian). Site 547 is located on the landward flank of a gneissic basement high in $3940.5 \mathrm{~m}$ water depth. As can be seen in Figure 2, the stratigraphic sequence at Site 547, in contrast to Site 545 , includes a Late Cretaceous and Paleogene section that pinches out toward the Mazagan Escarpment and ends in Triassic continental red beds at a terminal depth of $1030 \mathrm{~m}$ probably within a few (?)tens of meters from the basement.

In this study, the amount, type, and composition of organic matter in the Site 545 and 547 sediments are described, and the results are discussed in terms of its origin, depositional environment, and diagenetic alteration. A comparison will be made between the stratigraphically equivalent sediments from both sites. Furthermore, the results will be incorporated into the present knowledge of organic matter sedimentation along the Northwest African continental margin to improve the organofacies picture gained so far.

\section{EXPERIMENTAL METHODS}

The frozen samples were dried at $50^{\circ} \mathrm{C}$ for 12 hours and ground. Total organic carbon was determined with a LECO IR-112 carbon analyzer after treatment of the sediments with hydrochloric acid to remove the carbonate carbon. Extraction was performed using a modified flow-blending technique (Radke et al., 1978) and with dichloromethane as the extraction solvent. The total extracts were separated into nonaromatic hydrocarbons, aromatic hydrocarbons, and heterocomponents by automated medium-pressure liquid chromatography (Radke et al., 1980).

A Siemens L350 gas chromatograph equipped with a $23 \mathrm{~m} \times$ $0.3 \mathrm{~mm}$ ID glass capillary column coated with SE54 was used for gas chromatographic (GC) analysis of the nonaromatic hydrocarbon frac- 


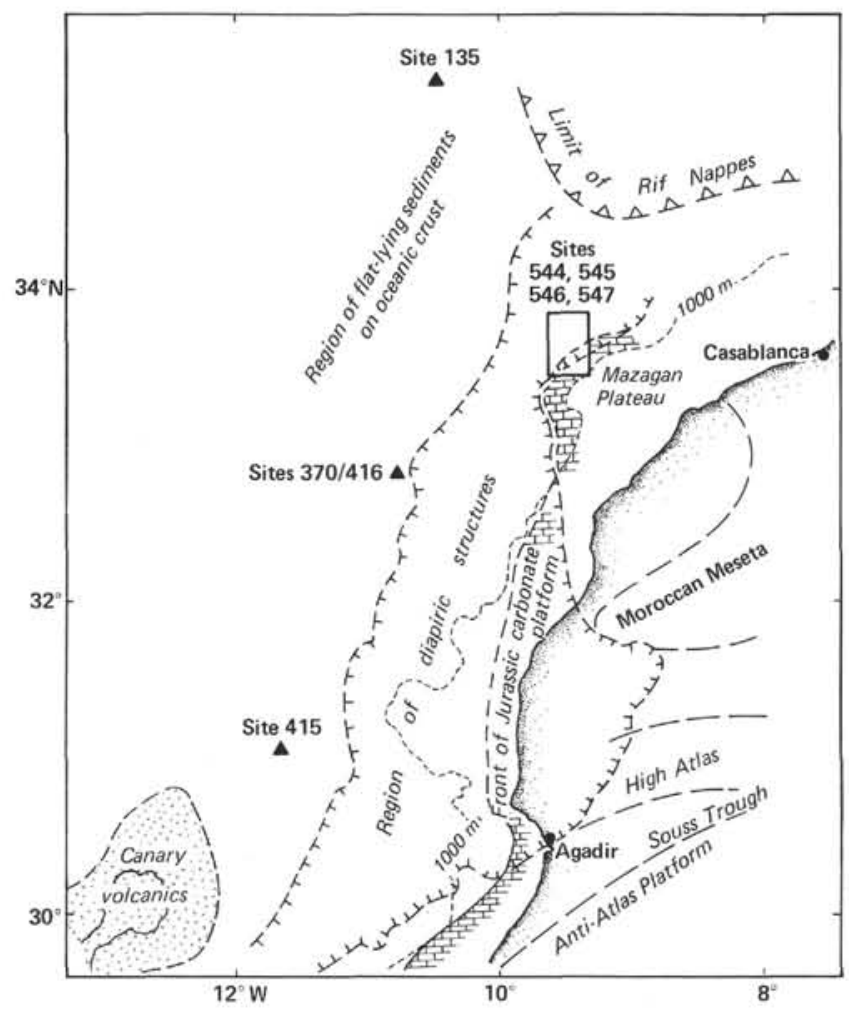

Figure 1. Location map of the Northwest African continental margin off Morocco indicating drill sites of DSDP Leg 50 (Sites 415 and 416) and Leg 79 (within rectangle) and major structural features (modified after Hinz et al., 1982).

tions. Helium was used as carrier gas. The temperature program was as follows: $80^{\circ} \mathrm{C}$ for $2 \mathrm{~min} ; 80$ to $254^{\circ} \mathrm{C}$ at a rate of $3^{\circ} \mathrm{C} / \mathrm{min}$.; isother$\mathrm{mal}$ at $254^{\circ} \mathrm{C}$ for $25 \mathrm{~min}$.

Gas chromatography/mass spectrometry (GC/MS) was carried out on a Varian MAT $112 \mathrm{~S}$ mass spectrometer linked directly to a Varian 3700 gas chromatograph via an open-split coupling. Samples were injected splitless onto a $25 \mathrm{~m} \times 0.3 \mathrm{~mm}$ ID fused silica column coated with SE54. Helium was used as carrier gas, and the temperature was programmed from 70 to $300^{\circ} \mathrm{C}$ at a rate of $4^{\circ} \mathrm{C} / \mathrm{min}$. The mass spectrometer was operated at an ionization energy of $80 \mathrm{eV}$. The source temperature was kept at $220^{\circ} \mathrm{C}$, and the magnet scanned continuously at a rate of $3 \mathrm{~s} / \mathrm{scan}$. All data were stored and processed using a DS $50 \mathrm{~S}$ on-line data system (Kratos AEI).

Rock-Eval pyrolysis was performed according to the method described by Espitalié et al. (1977). Hydrogen and oxygen contents of the rock samples, measured as hydrocarbon-type compound and carbon dioxide yields, respectively, were normalized to organic carbon and displayed as index values in a diagram adopted from Espitalié et al. (1977) and Roucaché et al. (1979).

Kerogen microscopy was restricted to samples containing more than $0.5 \% C_{\text {org }}$ and used both separated kerogens and whole rock samples. Spectral fluorescence was only performed on whole rock blocks in order to avoid effects of oxidation during kerogen separation. The separation procedure included treatment with $7.5 \mathrm{~N} \mathrm{HCl}$ followed by floatation in a density solution $\left(\mathrm{ZnI}_{2}, 1.9 \mathrm{~g} / \mathrm{cm}^{3}\right)$. The maceral types were analyzed using both transmitted and normal or fluorescence reflected light. For a description of maceral types, we refer to Gormly and Mukhopadhyay (1983) and Stach et al. (1982). Vitrinite reflectance (at $546 \mathrm{~nm}$ in oil) was measured on particles larger than $10 \mu \mathrm{m}$.

\section{RESULTS AND DISCUSSION}

\section{Organic Carbon}

The total organic carbon values of the sediment samples from DSDP Sites 545 and 547 investigated during this study are listed in Tables 1 and 2 . They are also plotted versus depth and in relation to lithology and stratigraphic age together with a number of shipboard data in Figures 3 and 4 . There is good coincidence of shipboard and shore-based organic carbon values although different analytical techniques were applied.

Within most of the Cenozoic sections the amount of organic matter accumulated in the sediments off the Mazagan Plateau was found to be very low (about $0.2 \%$ $\mathrm{C}_{\text {org }}$ ). Slightly elevated organic carbon values were measured for the early to middle Miocene clayey nannofossil chalks from Site 545, whereas the only major exception to the general trend is the Eocene debris flow sequence in Hole 547A where the organic carbon increases up to $5 \%$.

Small-scale slumping is common in the Cretaceous sections at both sites. This may partly be the reason for the high variability of organic carbon values especially at Site 545. This is well illustrated in Figure 3 for Core 545-34, where the total organic carbon varies between less than $0.5 \%$ and more than $2 \%$. This core mainly consists of claystone conglomerate and pebbly claystone with varying lithologic composition. In general, the midCretaceous sediments have organic carbon contents in excess of $0.5 \%$. At Site 545 , there appears to be an increase of organic carbon from late Cenomanian to late Albian followed by a decrease within the Aptian section. A major slump clast in Core 545-56 (late Aptian) shows higher values again. At Site 547, the Cretaceous section comprises a Late Cretaceous debris flow interval underlain by Cenomanian and Albian claystones, and a very short interval of Aptian to Valanginian age (not shown in Fig. 4). The organic carbon content of the mid-Cretaceous sediments steadily increases from about $0.7 \%$ at the top of the Cenomanian to about $2 \%$ at the base of the Albian with an exceptional value in excess of $3 \%$ in a dark slump clast at the very bottom of the Albian in Section 547B-6-1.

The Jurassic at Site 545 obviously consists of predominantly very organic-carbon-lean, mostly oxidized carbonates that were not sampled for organic geochemical investigation. The Jurassic sediments at Site 547 have highly variable organic carbon contents due to the presence of black shales embedded in a nodular limestone/ dolomite matrix. This interval has been studied in more detail (Table 2) using sedimentological criteria also to differentiate between facies types (M. Bradshaw, personal communication, 1982). Low values below about $0.5 \% \mathrm{C}_{\text {org }}$ are typical of the nodular micrite/claystone matrix in Subunit VIB of Hole 547B. The organic carbon contents of the black shale facies type A samples vary between $4.75 \%$ (Sample 547B-15-2, 8-12 cm) and $0.70 \%$ (Sample 547B-18-1, 100-117 cm), whereas single values only are available for facies type $\mathrm{B}\left(1.63 \% \mathrm{C}_{\text {org }}\right.$; Sample 547B-20-2, 92-104 cm) and type C samples $(0.39 \%$; Sample 547B-14-2, 56-58 cm). The variation observed is partly a consequence of the thin black shale layers grading downward into the organic-carbon-lean matrix facies, and the relatively large sample amounts required for detailed organic geochemical investigation; thus, the $\mathrm{C}_{\text {org }}$ data in Table 2 often represent average values over inhomogeneous intervals. Shipboard analysis 


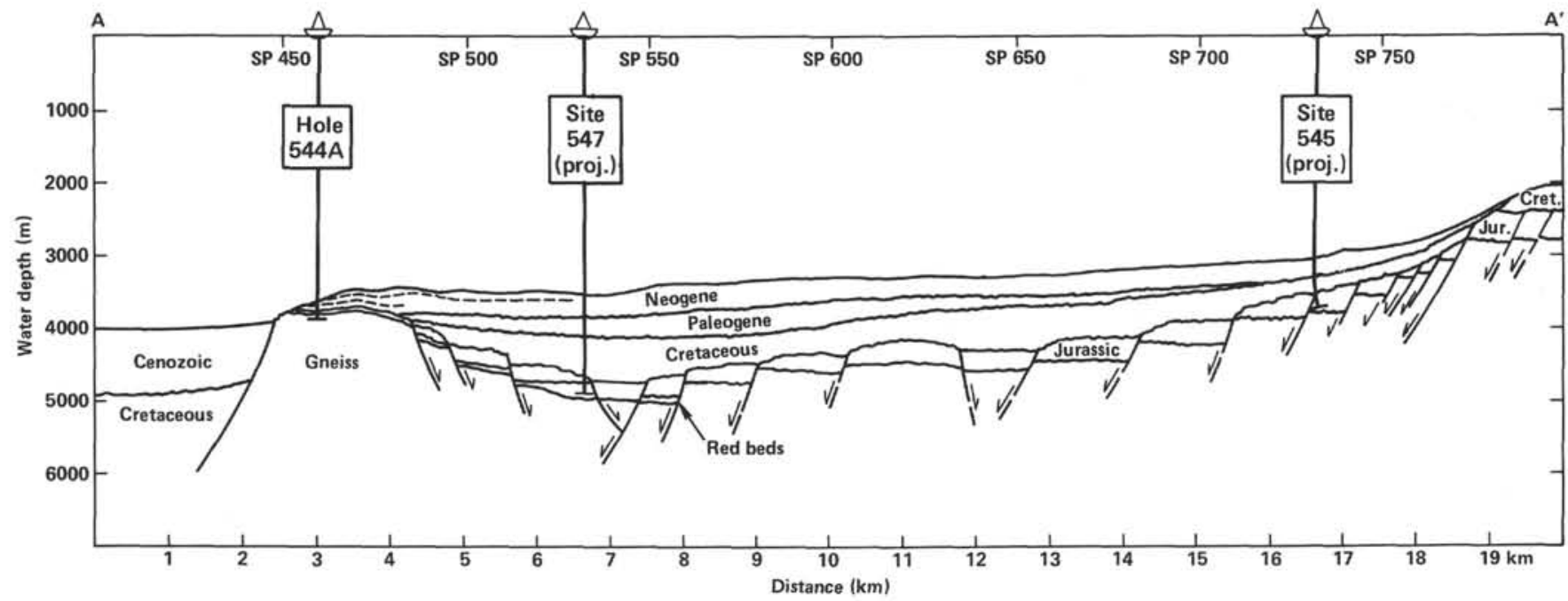

Figure 2. Geologic cross section along Meteor seismic profile 53-08 (A-A $\left.{ }^{1}\right)$ through DSDP Sites 544, 547 (projected), and 545 (projected). The seismic profile is approximately northwest-southeast through the rectangle shown in Figure 1 (modified after Hinz et al., 1982).

Table 1. Lithology, stratigraphy, organic carbon content, extract and liquid chromatography yields, and Rock-Eval pyrolysis data for core samples from DSDP Sites 545 and 547.

\begin{tabular}{|c|c|c|c|c|c|c|c|c|c|c|c|}
\hline \multirow[b]{2}{*}{$\begin{array}{c}\text { Sample } \\
\text { (interval in } \mathrm{cm} \text { ) }\end{array}$} & \multirow[b]{2}{*}{$\begin{array}{l}\text { Depth } \\
\text { (m) }\end{array}$} & \multirow[b]{2}{*}{ Lithology } & \multirow[b]{2}{*}{$\begin{array}{l}\text { Stratigraphic } \\
\text { age }\end{array}$} & \multirow[b]{2}{*}{$\begin{array}{l}C_{\text {org }} \\
(\%)\end{array}$} & \multirow[b]{2}{*}{$\begin{array}{c}\text { Extract } \\
\left.\text { (mg/g C } \text { org }^{2}\right)\end{array}$} & \multicolumn{3}{|c|}{ Liquid chromatography } & \multicolumn{3}{|c|}{ Rock-Eval pyrolysis } \\
\hline & & & & & & $\begin{array}{c}\begin{array}{c}\text { Nonaromatic } \\
\text { hydrocarbons } \\
(\%)\end{array} \\
\text { (\%) }\end{array}$ & $\begin{array}{c}\text { Aromatic } \\
\text { hydrocarbons } \\
(\%)\end{array}$ & $\begin{array}{c}\text { Hetero- } \\
\text { compounds } \\
(\%)\end{array}$ & $\begin{array}{c}\mathrm{HI} \\
(\mathrm{mg} \mathrm{hc} / \mathrm{g} \\
\left.\mathrm{C}_{\text {org }}\right)\end{array}$ & $\begin{array}{c}\mathrm{OI} \\
\underset{(\mathrm{mg} \mathrm{CO}}{\mathrm{O}} / \mathrm{g} \\
\left.\mathrm{C}_{\mathrm{org}}\right)\end{array}$ & $\begin{array}{l}\mathrm{T}_{\max } \\
\left({ }^{\circ} \mathrm{C}\right)\end{array}$ \\
\hline \multicolumn{12}{|l|}{ Site 545} \\
\hline $545-19-3,75-95$ & 173.9 & $\begin{array}{l}\text { Clayey nannofossil } \\
\text { ooze }\end{array}$ & late Miocene & 0.13 & 13 & n.d. & n.d. & n.d. & 27 & 995 & 369 \\
\hline $545-26-1,43-62$ & 237.0 & $\begin{array}{l}\text { Clayey nannofossil } \\
\text { chalk }\end{array}$ & middle Miocene & 0.60 & 15 & n.d. & n.d. & n.d. & 67 & 257 & 418 \\
\hline $545-31-1,49-65$ & 284.6 & Nannofossil clay & $\begin{array}{l}\text { late } \\
\text { Cenomanian }\end{array}$ & 1.01 & 13 & 10 & 5 & 85 & 89 & 146 & 428 \\
\hline $545-34-1,70-81$ & 313.3 & Claystone clast & $\begin{array}{l}\text { middle } \\
\text { Cenomanian }\end{array}$ & 1.90 & 12 & 7 & 4 & 89 & 207 & 75 & 426 \\
\hline $545-38-1,65-80$ & 351.2 & $\begin{array}{l}\text { Nannofossil- } \\
\text { bearing clay- } \\
\text { stone }\end{array}$ & late Albian & 1.30 & 8 & 9 & 1 & 90 & 108 & 113 & 424 \\
\hline $545-43-2,130-140$ & 400.9 & $\begin{array}{l}\text { Nannofossil- } \\
\text { bearing clay- } \\
\text { stone }\end{array}$ & middle Albian & 2.29 & 11 & 9 & 5 & 86 & 300 & 49 & 424 \\
\hline $545-53-1,100-120$ & 494.1 & $\begin{array}{l}\text { Nannofossil- } \\
\text { bearing clay- } \\
\text { stone }\end{array}$ & late Aptian & 0.56 & 9 & n.d. & n.d. & n.d. & 65 & 130 & 424 \\
\hline $545-56-1,110-128$ & 522.7 & $\begin{array}{l}\text { Muddy nannofos- } \\
\text { sil ooze (clast) }\end{array}$ & late Aptian & 0.99 & 11 & n.d. & n.d. & n.d. & 130 & 70 & 425 \\
\hline \multicolumn{12}{|l|}{ Hole 547A } \\
\hline $547 \mathrm{~A}-16-3,90-105$ & 216.5 & $\begin{array}{l}\text { Clayey nannofossil } \\
\text { chalk }\end{array}$ & late Eocene & 0.30 & 14 & 2 & 0 & 98 & 31 & 305 & 408 \\
\hline $547 \mathrm{~A}-20-3,60-75$ & 254.2 & $\begin{array}{l}\text { Clayey nannofossil } \\
\text { chalk }\end{array}$ & late Eocene & 3.96 & 8 & 5 & 4 & 91 & 431 & 71 & 415 \\
\hline $547 \mathrm{~A}-35-2,15-30$ & 394.7 & $\begin{array}{l}\text { Clayey nannofossil } \\
\text { chalk }\end{array}$ & $\begin{array}{l}\text { late } \\
\text { Campanian }\end{array}$ & 0.06 & 207 & 6 & 12 & 82 & 23 & 1357 & n.d. \\
\hline $547 \mathrm{~A}-41-1,30-48$ & 440.9 & Claystone & Cenomanian & 0.67 & 9 & 16 & 9 & 75 & 33 & 131 & 413 \\
\hline $547 \mathrm{~A}-56-1,23-28$ & 583.3 & $\begin{array}{l}\text { Nannofossil- } \\
\text { bearing clay- } \\
\text { stone }\end{array}$ & Cenomanian & 0.74 & 9 & 21 & 18 & 61 & 43 & 175 & 413 \\
\hline $547 \mathrm{~A}-66-2,115-130$ & 680.7 & $\begin{array}{l}\text { Nannofossil- } \\
\text { bearing mud- } \\
\text { stone }\end{array}$ & Albian & 0.69 & 8 & 19 & 18 & 63 & 84 & 80 & 434 \\
\hline \multicolumn{12}{|l|}{ Hole 547B } \\
\hline $547 \mathrm{~B}-5-6,83-101$ & 770.9 & $\begin{array}{l}\text { Nannofossil- } \\
\text { bearing clay- } \\
\text { stone }\end{array}$ & Albian & 1.29 & 11 & 13 & 9 & 78 & 110 & 34 & 431 \\
\hline $547 \mathrm{~B}-6-1,77-84$ & 772.8 & $\begin{array}{l}\text { Nannofossil- } \\
\text { bearing clay- } \\
\text { stone (slump } \\
\text { clast) }\end{array}$ & Albian & 1.87 & 14 & 21 & 7 & 72 & 244 & 42 & 426 \\
\hline $547 \mathrm{~B}-30-3,59-75$ & 981.2 & Sandy mudstone & Triassic (?) & 0.28 & 12 & 12 & 21 & 67 & 20 & 27 & 446 \\
\hline
\end{tabular}

Note: n.d. $=$ not determined. 
Table 2. Organic carbon content, Rock-Eval pyrolysis data, and extract and liquid chromatography yields for core samples from the Jurassic black shale sequence of DSDP Hole 547B, Mazagan Escarpment.

\begin{tabular}{|c|c|c|c|c|c|c|c|c|c|c|}
\hline \multirow[b]{2}{*}{$\begin{array}{c}\text { Sample } \\
\text { (interval in } \mathrm{cm} \text { ) }\end{array}$} & \multirow[b]{2}{*}{$\begin{array}{l}\text { Depth } \\
\text { (m) }\end{array}$} & \multirow[b]{2}{*}{ Facies type ${ }^{a}$} & \multirow[b]{2}{*}{$\begin{array}{l}\mathrm{C}_{\text {org }} \\
(\%)\end{array}$} & \multicolumn{3}{|c|}{ Rock-Eval pyrolysis } & \multirow[b]{2}{*}{$\begin{array}{c}\text { Extract } \\
\text { (mg/g Corg) }\end{array}$} & \multicolumn{3}{|c|}{ Liquid chromatography } \\
\hline & & & & $\begin{array}{c}\mathrm{HI} \\
\text { (mg hc/g } \\
\mathrm{C}_{\text {org }} \text { ) }\end{array}$ & $\begin{array}{c}\mathrm{OI} \\
\text { (mg CO} \mathrm{CO}_{2} / \mathrm{g} \\
\mathrm{C}_{\text {org }} \text { ) }\end{array}$ & $\begin{array}{l}\mathrm{T}_{\max } \\
\left({ }^{\circ} \mathrm{C}\right)\end{array}$ & & $\begin{array}{c}\text { Nonaromatic } \\
\text { hydrocarbons } \\
(\%)\end{array}$ & $\begin{array}{c}\text { Aromatic } \\
\text { hydrocarbons } \\
(\%)\end{array}$ & $\begin{array}{l}\text { Hetero- } \\
\text { compounds } \\
(\%)\end{array}$ \\
\hline 547B-14-2, 56-58 & 839.07 & $\mathrm{C}$ & 0.39 & 19 & 122 & 434 & - & - & - & - \\
\hline $547 \mathrm{~B}-15-2,2-5$ & 847.54 & $\begin{array}{l}\text { Nodular micrite } \\
\text { and claystone }\end{array}$ & 0.30 & 12 & 269 & $426 / 534$ & - & - & - & - \\
\hline $547 \mathrm{~B}-15-2,8-12$ & 847.60 & A & 4.75 & 345 & 15 & 421 & 10 & 16 & 12 & 72 \\
\hline 547B-15-2, 14-17 & 847.66 & A & 1.13 & 49 & 87 & 421 & 13 & 23 & 13 & 64 \\
\hline $547 \mathrm{~B}-15-2,20-26$ & 847.73 & $\begin{array}{l}\text { Nodular micrite } \\
\text { and claystone }\end{array}$ & 0.69 & 18 & 142 & 422 & 11 & 32 & 11 & 57 \\
\hline $547 \mathrm{~B}-15-2,39-41$ & 847.90 & $\begin{array}{l}\text { Nodular micrite } \\
\text { and claystone }\end{array}$ & 0.28 & 7 & 377 & $427 / 534$ & - & - & - & - \\
\hline 547B-16-1, 29-42 & 855.36 & $\begin{array}{l}\text { Nodular micrite } \\
\text { and claystone }\end{array}$ & 0.10 & 8 & 302 & $424 / 524$ & - & - & - & - \\
\hline 547B-18-1, 100-117 & 874.09 & A & 0.70 & 18 & 137 & 425 & 5 & 18 & 5 & 77 \\
\hline $547 \mathrm{~B}-20-1,134-140$ & 892.37 & $\begin{array}{l}\text { Nodular micrite } \\
\text { and claystone }\end{array}$ & 0.92 & 71 & 113 & 424 & - & - & - & - \\
\hline 547B-20-2, 92-104 & 893.48 & B & 1.63 & 188 & 37 & 428 & 16 & 9 & 12 & 79 \\
\hline 547B-21-2, 16-19 & 897.18 & $\begin{array}{l}\text { Matrix from } \\
\text { debris flow }\end{array}$ & 0.51 & 68 & 89 & 428 & - & - & - & - \\
\hline 547B-22-1, 13-18 & 905.16 & A & 1.03 & 31 & 46 & 421 & 13 & 21 & 21 & 58 \\
\hline 547B-22-1, 38-42 & 905.40 & Claystone & 0.44 & 18 & 167 & 419 & - & - & - & - \\
\hline $547 \mathrm{~B}-23-1,45-55$ & 915.00 & $\begin{array}{l}\text { Nodular micrite } \\
\text { and claystone }\end{array}$ & 0.11 & 19 & 395 & 514 & - & - & - & - \\
\hline
\end{tabular}

Note: $-=$ not determined.

a M. Bradshaw, personal communication 1982: facies type A to C are different "black shales" based on sedimentological criteria only. Details to be published.

of small chips from the very top of the black shale sections resulted in organic carbon values near 7\% (Sample 547B-20-1, 13-15 cm; site chapter, Site 547, this volume) or even above $10 \%$ (V. Vuchev, personal communication, 1981). Facies C does not appear organic-matterrich with respect to the background level. It may be a pyrite-rich, clast-free layer within the gravel unit (debris flow), and the poorly developed lamination could be a compaction feature (M. Bradshaw, personal communication, 1982).

The red and gray sandy mudstones of probably Triassic age have low organic carbon contents below $0.5 \%$.

\section{Kerogen Composition}

\section{Rock-Eval Pyrolysis}

Kerogen analysis by Rock-Eval pyrolysis (Espitalié et al., 1977) showed hydrocarbon yields, normalized to organic carbon, generally increasing with increasing total organic carbon content. This indicates an increase in kerogen quality with improving environmental conditions for organic matter preservation. Hydrogen-index values of shore-based and shipboard measurements are consistent, whereas oxygen-index values appear to be lower by a factor of about two in shore-based studies. This should be kept in mind during the following discussion of Figures 5 and 6 (cf., also, site chapters, this volume).

There is a pronounced difference of kerogen type between the Cenozoic and the Cretaceous sediments from Site 545 (Fig. 5). The organic matter in most of the Cenozoic sediments apparently is strongly oxidized resulting in low hydrogen-index and very high oxygen-index values. Only a few middle Miocene samples contain moderately preserved terrigenous organic matter, and in the
Rock-Eval diagram they plot close to the kerogen type III trend line (cf. Tissot et al., 1974, for definition of kerogen types). Among the Cretaceous sediments, the late Cenomanian samples have a kerogen type similar to the middle Miocene samples just above the unconformity (terrigenous organic matter; type III). In the late Aptian to middle Cenomanian section, the hydrogen indexes are higher, but variable between 100 and $300 \mathrm{mg}$ hydrocarbons $/ \mathrm{g} \mathrm{C}_{\text {org }}$ with the higher values particularly occurring in slump clasts (Table 1; site chapter, Site 545 this volume). The position of these samples in the RockEval diagram (Fig. 5) indicates a mixture of mainly well preserved terrigenous organic matter with variable amounts of marine organic matter. The sample plotting in the top right of the diagram is probably contaminated.

Site 547 sediments may be classified into four different groups, those falling into the three encircled areas in Figure 6 and those close to the $\mathrm{x}$-axis outside these areas. The circles originally were defined based only on shipboard data, but most of the shore-based results are consistent with this difference if an allowance is made for a shift in oxygen-index values (shipboard values probably too high due to experimental problems). The data points outside the encircled areas, close to the $\mathrm{x}$-axis, in Figure 6 comprise the sediments containing severely oxidized and/or reworked organic matter that occur in the organic-carbon-lean sections predominantly of Cenozoic, but also of Triassic through Cretaceous age (cf. Tables 1 and 2; and site chapter, Site 547, this volume). The encircled area at the right-hand end of the kerogen type III trend line mainly contains the Cenomanian sediments that have organic carbon contents close to $0.7 \%$. The organic matter appears to be of terrigenous origin; it is hydrogen deficient and probably slightly oxidized. 


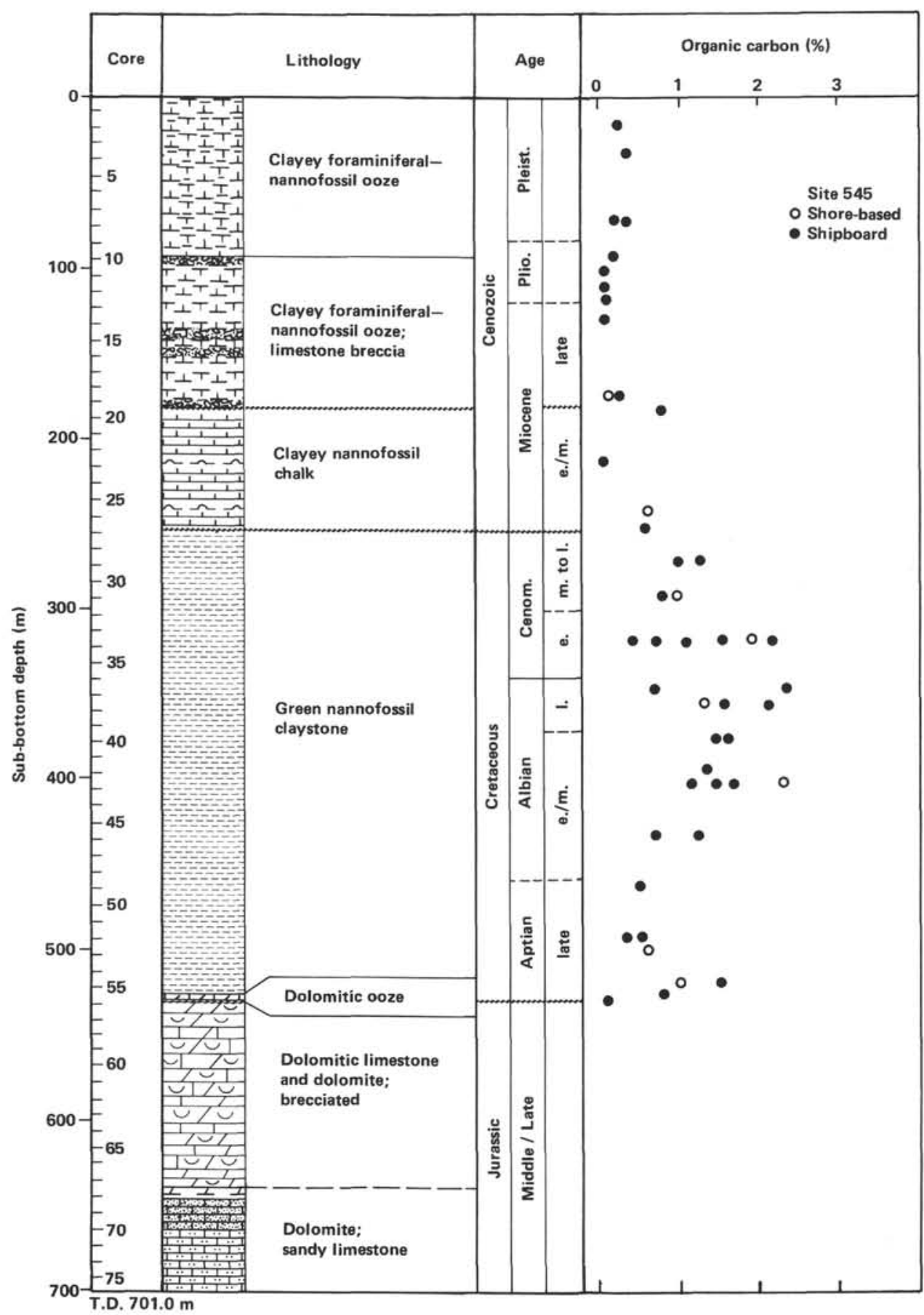

Figure 3. Variation of organic carbon values with depth and lithology for DSDP Site 545 sediments. There is a good coincidence of shore-based and shipboard values despite different analytical techniques.

The Albian claystones have hydrogen-index values between about 100 and $250 \mathrm{mg}$ hydrocarbons/g $\mathrm{C}_{\text {org }}$ and are located in the area just above the kerogen type III trend line together with a few Jurassic black shale samples. The relatively low oxygen-index values indicate environmental conditions favorable for the preservation of organic matter. The data suggest a kerogen composition of mixed terrigenous (predominant) and marine organic matter. The organic matter of the sediments combined in the third encircled area in Figure 6 is characterized by high hydrogen-index and low oxygen-index values. Most of the samples are from the Eocene slump sequence in Cores 547A-17 through 547A-20. Their kerogen appears to be of marine planktonic or algal origin with very low to moderate admixtures of terrigenous organic matter. A Jurassic black shale sample from Core 547B-20 and an Albian slump sample (Section 547B-6-1) also fall into the same area. A few Jurassic samples below this area indicate the transition from the black shale into the matrix facies (cf. Table 2). 


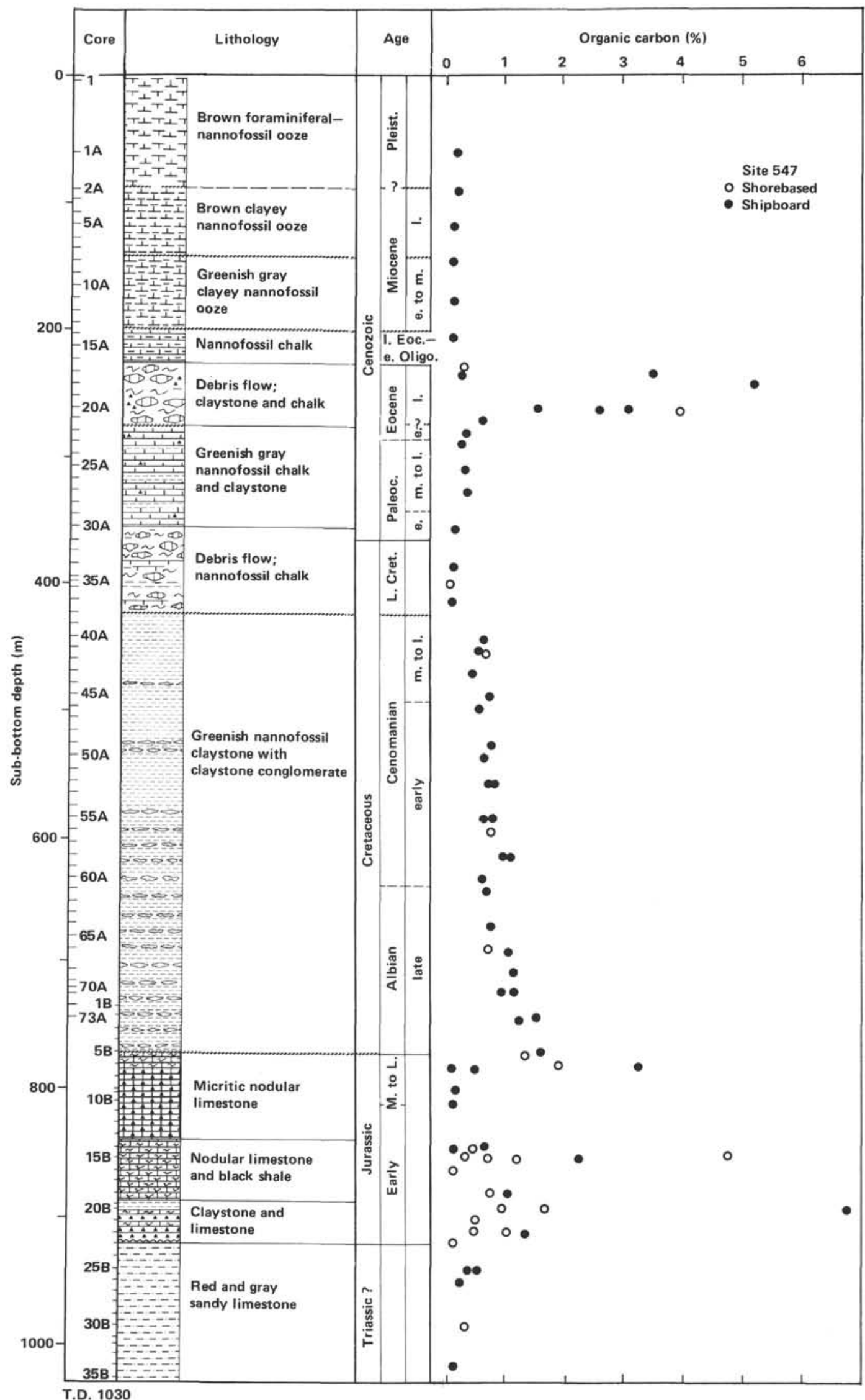

Figure 4. Variation of organic carbon values with depth and lithology for DSDP Site 547 sediments. There is a good coincidence of shore-based and shipboard values despite different analytical techniques. 


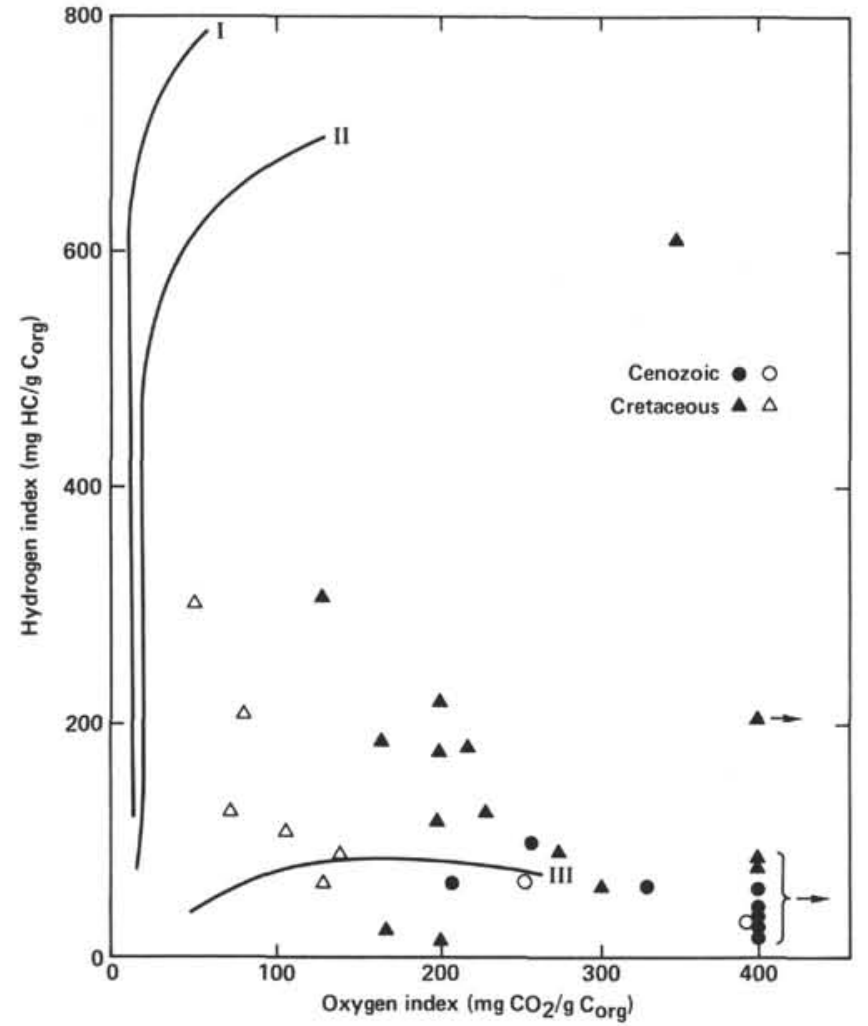

Figure 5. Results of Rock-Eval pyrolysis displayed as hydrogen index versus oxygen index diagram for DSDP Site 545 sediments. Closed symbols indicate shipboard data, open symbols are from shorebased studies.

\section{Maceral Analysis}

In Figure 7 the maceral compositions of the Site 545 sediments are compiled. The kerogen of the middle Miocene sample (545-26-1, 43-62 cm) mainly consists of amorphous material $(90 \%)$ less than $3 \mu \mathrm{m}$ in size. It appears fluffy in transmitted light, and it is mixed with framboidal pyrite. The major portion of the amorphous material ( $70 \%$ of total macerals) is of humic nature, nonfluorescent, and has a granular, gray appearance in normal reflected light. The rest $(20 \%)$ shows a dark yellowish brown fluorescence and a lower reflectance than the amorphous humic matter. Particulate liptinite is absent.

The two Cenomanian samples from Sections 545-31-1 and 545-34-1 differ from each other by the relative proportion of amorphous and particulate organic matter; the latter increases with increasing organic carbon content (Fig. 7). Both samples have received a slightly higher contribution from marine sources than the Miocene sample described previously. The terrigenous influence, however, is still dominant. The late Albian sediment (Sample $545-38-1,65-80 \mathrm{~cm}$ ) is similar to the middle Cenomanian sample with respect to the relative amounts of amorphous and particulate organic matter, but in the former the proportion of humic amorphous material is higher. The middle Albian Sample 545-43-2, 130-140 cm, which is the richest in organic carbon within the Site 545 series, also contains the highest amount of marine or-

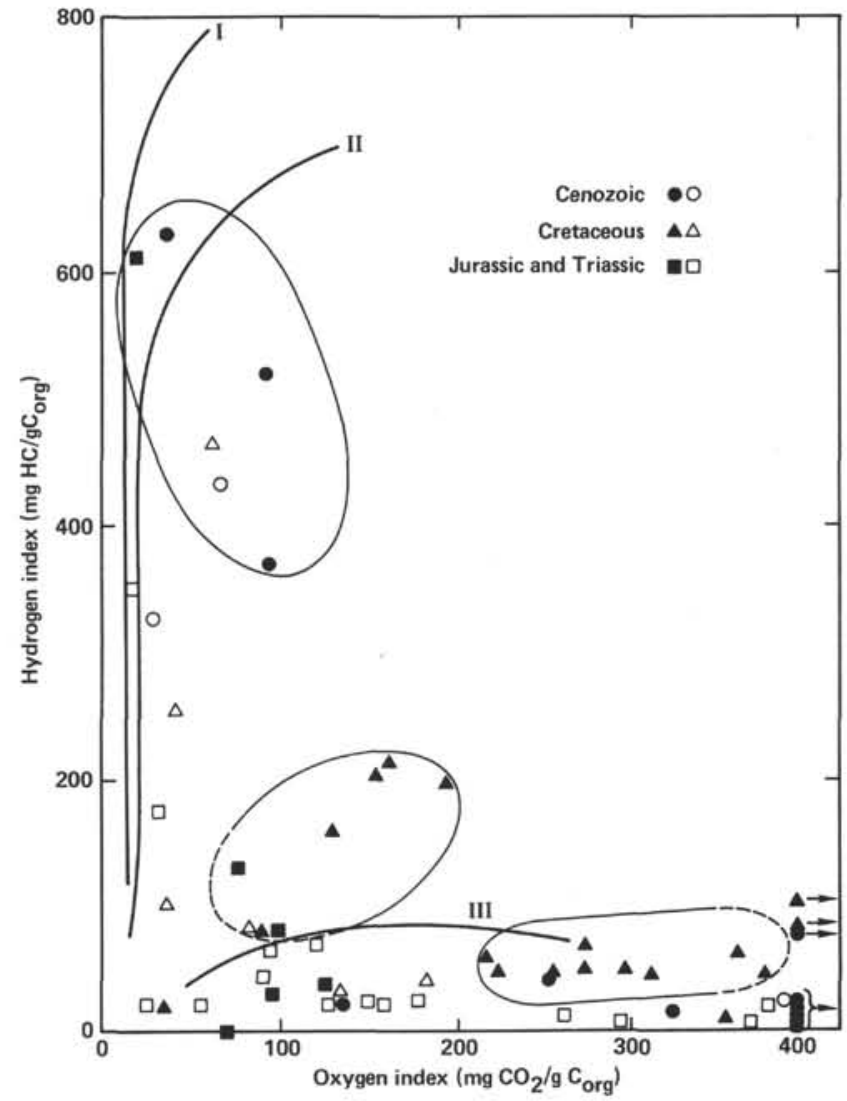

Figure 6. Results of Rock-Eval pyrolysis displayed as hydrogen index versus oxygen index diagram for DSDP Site 547 sediments. Closed symbols indicate shipboard data, open symbols are from shorebased studies.

ganic matter ( $47 \%$ based on maceral composition; sum of particulate and biodegraded phyto- and zooclasts), whereas the organic matter in the late Aptian sediment appears to be entirely of terrigenous origin. Finally, the late Aptian sample near the base of the mid-Cretaceous section (Sample 545-56-1, 110-128 cm) contains a mixture of marine and terrestrial organic matter with the latter type dominating.

The maceral composition of the Hole 547A and Hole 547B sediments (Fig. 8; Table 3) indicates that a highly variable depositional environment has influenced the preservation of organic matter. The sample from the Eocene debris flow section contains a very high amount of liptinite, both particulate and degraded, and the marine portion of this amounts to more than $50 \%$. The alginite $(8 \%)$ is mainly derived from small, unicellular algae that possibly were of the Nostocopsis sp. type. The marine particulate liptinite occasionally shows degraded remnants of dinoflagellates that have a brownish yellow fluorescence. Residual or inert organic matter is not common in this sample.

Samples 547A-56-1, 23-28 cm (Cenomanian); 547A66-2, 115-130 cm; and 547B-5-6, 83-101 cm (both late Albian) are similar to each other in that they all contain more than $85 \%$ terrigenous organic matter based on maceral analysis (Fig. 8). The predominant particles are vitrinites, inertinites, and higher plant liptinites. The pro- 


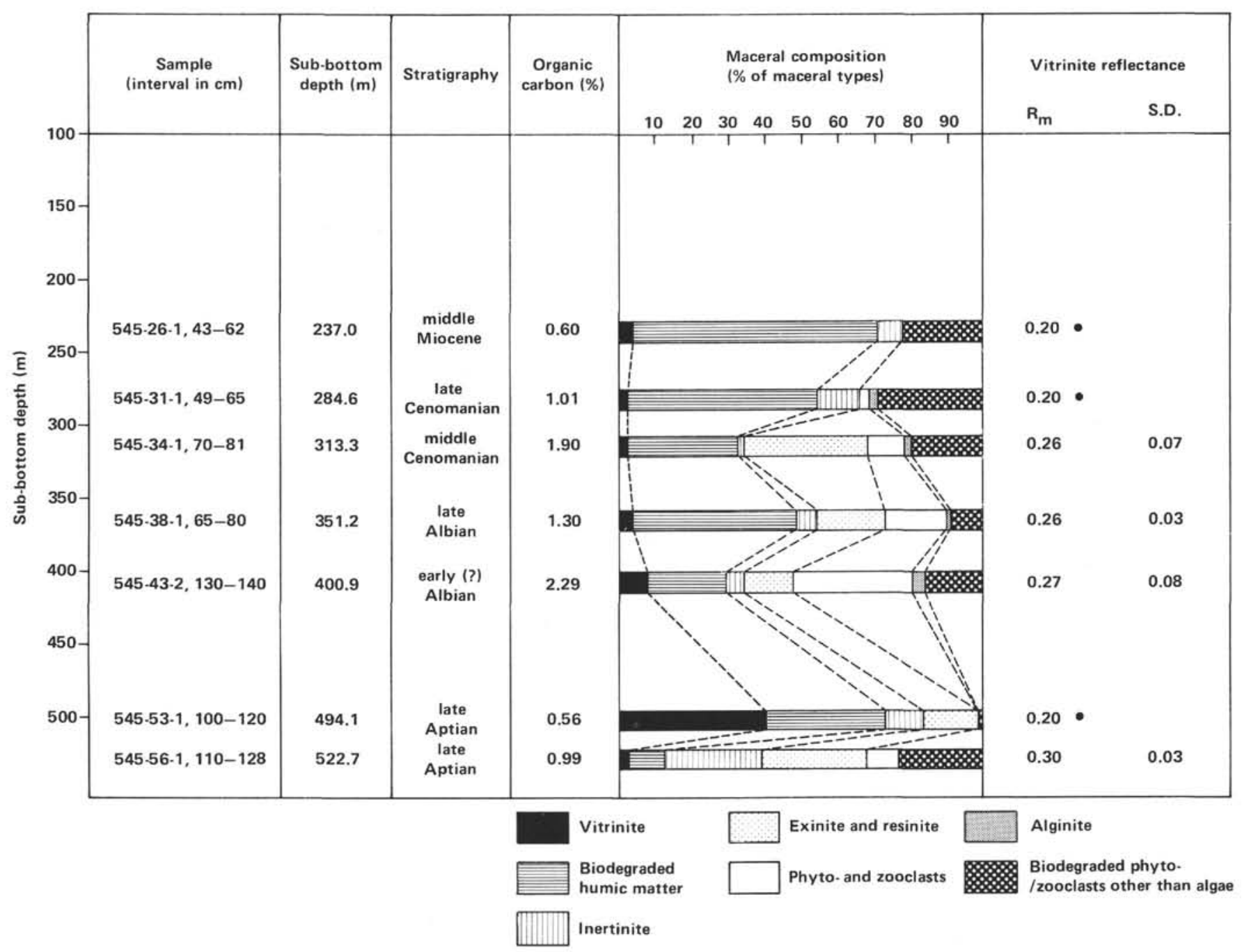

Figure 7. Maceral composition and vitrinite reflectance of DSDP Site 545 sediments. $R_{m}$ values marked with a dot are converted from spectral fluorescence measurements.

portion of the terrigenous liptinites increases with depth. Most of the sporinites and cutinites seem to be recycled since the spore color is mostly dark brown although some transparent greenish yellow spores are also present in all three samples. The amount of biodegraded, amorphous organic matter is minor in each case. The deepest Albian sample (Sample 547B-6-1, 77-84 cm) is a slump clast and has a different maceral composition compared to the other three Cretaceous sediments. Biodegraded organic matter dominates, and the proportion of nonfluorescent humic amorphous matter exceeds that of the degraded, amorphous liptinite (brownish yellow fluorescence). The contribution from marine sources is higher than in the shallower Cretaceous samples.

The maceral composition of the Jurassic sediments from the black shale sequence in Cores 547B-14 to 547B22 is shown in Table 3 . Of the three samples studied from Section 547B-15-2 the shallowest interval (8-12 $\mathrm{cm})$ contains a kerogen with a high proportion of liptinite mostly as sporinite and cutinite or as degraded spores and cuticles. In addition to these terrigenous liptinite components, a fair amount of dinoflagellates and organic-matter-coated foraminifers (zoo- and phytoclasts) is present, whereas unicellular algae are scarce. In the case of the foraminifers, however, humic organic matter appears to have replaced the carbonate shell, and the foraminiferal lipids were lost since the particles do not show the characteristic fluorescence. From the composition of the lipid particles in total it is assumed that the unstructured liptinite (bituminite II) in the kerogen of Sample 547B-15-2, 8-12 cm is a typical mixture of degraded higher plant and phyto-/zooclast liptinites (for the nomenclature of unstructured liptinites, see Gormly and Mukhopadhyay, 1983). The inertinite (residual or oxidized ligno-cellulose components) content in this sample is low and is exceeded by the amount of vitrinite particles (ligno-cellulose components of higher plants). An appreciable proportions of recycled vitrinites $\left(R_{m} \approx\right.$ $0.7 \%$ ) and brown recycled spores also were noticed. Based on the total maceral composition, the kerogen of Sample 547B-15-2, 8-12 cm may be classified as type II-III according to Tissot et al. (1974).

The two less organic-matter-rich intervals of Section 547B-15-2 (14-17 and 20-26 cm) are very similar to each 


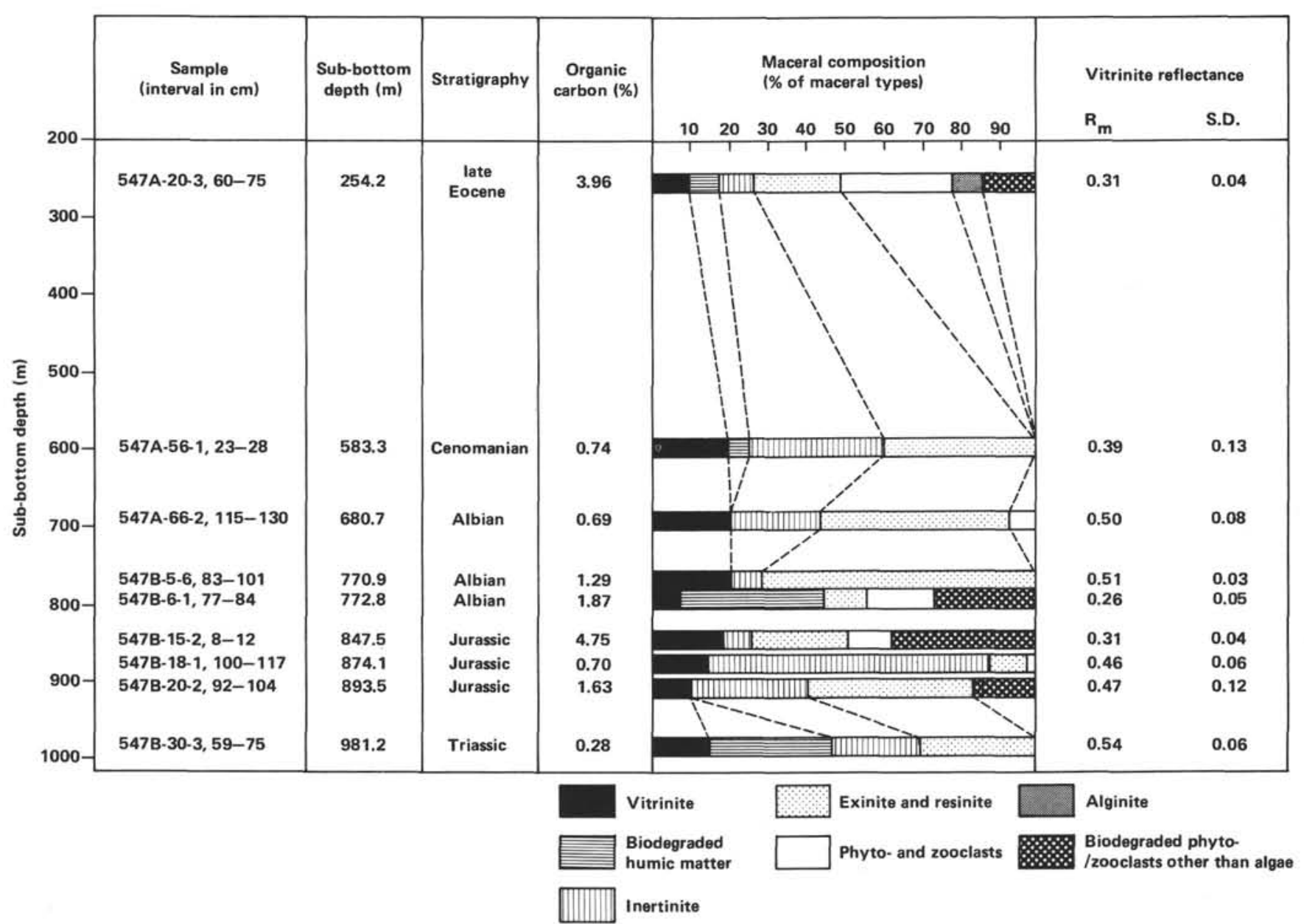

Figure 8. Maceral composition and vitrinite reflectance of DSDP Site 547 sediments.

Table 3. Organic petrography of core samples from the Jurassic black shale sequence of DSDP Hole 547B, Mazagan Escarpment. The results of the kerogen microscopy provide information on the type (maceral composition) and maturity of the organic matter (vitrinite reflectance, spectral fluorescence).

\begin{tabular}{|c|c|c|c|c|c|c|c|c|c|c|c|c|c|}
\hline \multirow{4}{*}{$\begin{array}{c}\text { Sample } \\
\text { (interval in } \mathrm{cm} \text { ) }\end{array}$} & \multirow{4}{*}{$\begin{array}{l}\text { Depth } \\
\text { (m) }\end{array}$} & \multirow{2}{*}{\multicolumn{6}{|c|}{ Maceral composition (vol. \%) }} & \multicolumn{6}{|c|}{ Maturation } \\
\hline & & & & & & & & \multirow{2}{*}{\multicolumn{2}{|c|}{$\begin{array}{l}\text { Vitrinite } \\
\text { reflectance }\end{array}$}} & \multicolumn{4}{|c|}{ Spectral fluorescence } \\
\hline & & \multirow[b]{2}{*}{ Vitrinite } & \multirow[b]{2}{*}{ Inertinite } & \multicolumn{2}{|c|}{$\begin{array}{c}\text { Particulate } \\
\text { liptinite }\end{array}$} & \multirow[b]{2}{*}{ Alginite } & \multirow{2}{*}{$\begin{array}{c}\text { Bituminite } \\
\text { II }\end{array}$} & & & \multicolumn{2}{|c|}{ Sporinite } & \multicolumn{2}{|c|}{$\begin{array}{l}\text { Recycled } \\
\text { sporinite }\end{array}$} \\
\hline & & & & A & B & & & $\mathbf{R}_{\mathrm{m}}$ & S.D. & $\lambda_{\max }(\mathrm{nm})$ & $Q$ & $\lambda_{\max }(\mathrm{nm})$ & $Q$ \\
\hline $547 \mathrm{~B}-15-2,8-12$ & 847.54 & 19 & 7 & 25 & 11 & 2 & 36 & 0.31 & 0.04 & 510 & 0.49 & 570 & 0.69 \\
\hline $547 \mathrm{~B}-15-2,14-17$ & 847.60 & 14 & 51 & $35^{\mathrm{a}}$ & 0 & 0 & 0 & 0.40 & 0.07 & 528 & 0.55 & 580 & 0.78 \\
\hline $547 \mathrm{~B}-15-2,20-26$ & 847.66 & 8 & 58 & $34^{\mathrm{a}}$ & 0 & 0 & 0 & 0.43 & 0.07 & 537 & 0.33 & 591 & 1.02 \\
\hline 547B-18-1, 100-117 & 874.09 & 15 & 72 & 12 & 1 & 0 & 0 & 0.46 & 0.06 & 544 & 0.53 & 595 & 1.21 \\
\hline 547B-20-2, 92-104 & 893.48 & 9 & 32 & 42 & 2 & 0 & 15 & 0.47 & 0.12 & 530 & 0.59 & 600 & 1.00 \\
\hline
\end{tabular}

Note: Vitrinite $=$ telocollinite + desmocollinite + corpocollinite; particulate liptinite $\mathbf{A}=$ resinite, cutinite, suberinite, sporinite (terrestrial origin); particulate liptinite B = phyto- and zooclasts other than algae (marine origin); bituminite II = degraded phyto- and/or zooclasts mixed with degraded terrestrial liptinite (terrigenous/marine).

${ }^{\text {a }}$ Mainly recycled.

other in maceral composition despite the difference in organic carbon values (Tables 2 and 3). The liptinite particles (about $35 \%$ of total macerals) consist of sporinite, cutinite, and suberinite from terrestrial higher plants, but are mostly recycled; this is suggested by the presence of a few transparent greenish yellow spores among the bulk amount of brown spores. Inertinite is the domi- nant maceral type in both samples, mainly as highly reflecting $\left(R_{m}>2.0 \%\right)$ inertodetrinites (Stach et al., 1982) together with very few macrinites (large inertinite particles). Nearly all vitrinite particles in both samples are recycled. No macerals derived from marine organic matter (i.e., algae, phyto- and zooplankton) were found. The maceral composition of both samples supports the low 
hydrogen-index (HI) values found by Rock-Eval pyrolysis (Table 2). The kerogen in Sample 547B-15-2, 14-17 $\mathrm{cm}$ is of type III (Tissot et al., 1974), whereas it tends to type IV (slightly stronger oxidation; below type III evolution path in Fig. 6; cf. Bostick, 1979) in Sample $547 \mathrm{~B}-15-2,20-26 \mathrm{~cm}$. The recycled nature of most of the organic matter explains why both samples appear in an advanced stage on the evolution path in Figure 6.

The organic matter in Sample 547B-18-1, 100-117 cm (facies A) mainly consists of residual or oxidized components (inertinite). Liptinite particles account for only $13 \%$ of the total maceral composition and are derived from terrestrial higher plants (sporinite, cutinite). In the pyrolysis diagram (Fig. 6) this sample is found close to Sample 547B-15-2, 20-26 cm below the kerogen type III evolution path, which supports the microscopic evidence of a dominance of residual and oxidized organic matter in Sample 547B-18-1, 100-117 cm.

Sample 547B-20-2, 92-104 cm (facies B) revealed a kerogen dominated by liptinite components $(57 \%)$ mainly derived form terrestrial higher plants (sporinite, cutinite, etc.). About $30 \%$ of the spores and pollen are recycled and are recognized by their brown color that contrasts to the transparent greenish yellow appearance of primary spores. A significant proportion of the liptinite is unstructured (bituminite II), partly as liptodetrinite (Stach et al., 1982), but mainly consists of brown detritus of spores and pollen that are slightly degraded. The kerogen in total may be classified as type II-III (Tissot et al., 1974) similar to that in Sample 547B-15-2, 8-12 $\mathrm{cm}$. The main difference is the higher proportion of marine lipid material in the latter sample and a reversed vitrinite/inertinite ratio.

Figure 9 is an attempt to relate the liptinite content of the DSDP Leg 79 sediments to the hydrogen-index values from Rock-Eval pyrolysis. Four clusters are shown that are marked as corresponding to different kerogen types (cf. Tissot et al., 1974; Bostick, 1979) similar to those indicated in Figures 5 and 6 (kerogen type IV is the inert, oxidized organic matter type not specifically marked in those figures). In Figure 9 there is the expected general increase of hydrogen-index values with liptinite content. This increase is due to the fact that the liptinite macerals are the most hydrogen-rich components of the organic matter. Increasing hydrogen richness (or liptinite content) often coincides with an increase of the marine organic matter proportion in the kerogen. The unusual feature in Figure 9 is the wide spread of the samples classified as bearing type III (terrigenous) organic matter. There is a wide range of the relative amounts of liptinite in the kerogens without much change of the hydrogen-index values. This relation can be explained by the observation that the particulate liptinites in the liptinite-rich Samples 547A-66-2, 115-130 cm; $547 \mathrm{~B}-5-6,83-101 \mathrm{~cm}$; and 547B-20-2, 92-104 cm are mostly recycled resulting in low hydrogen-index values.

\section{Extractable Hydrocarbons}

The total extract yields, normalized to organic carbon, are listed in Tables 1 and 2. With the exception of the extremely organic-carbon-lean late Campanian sam-

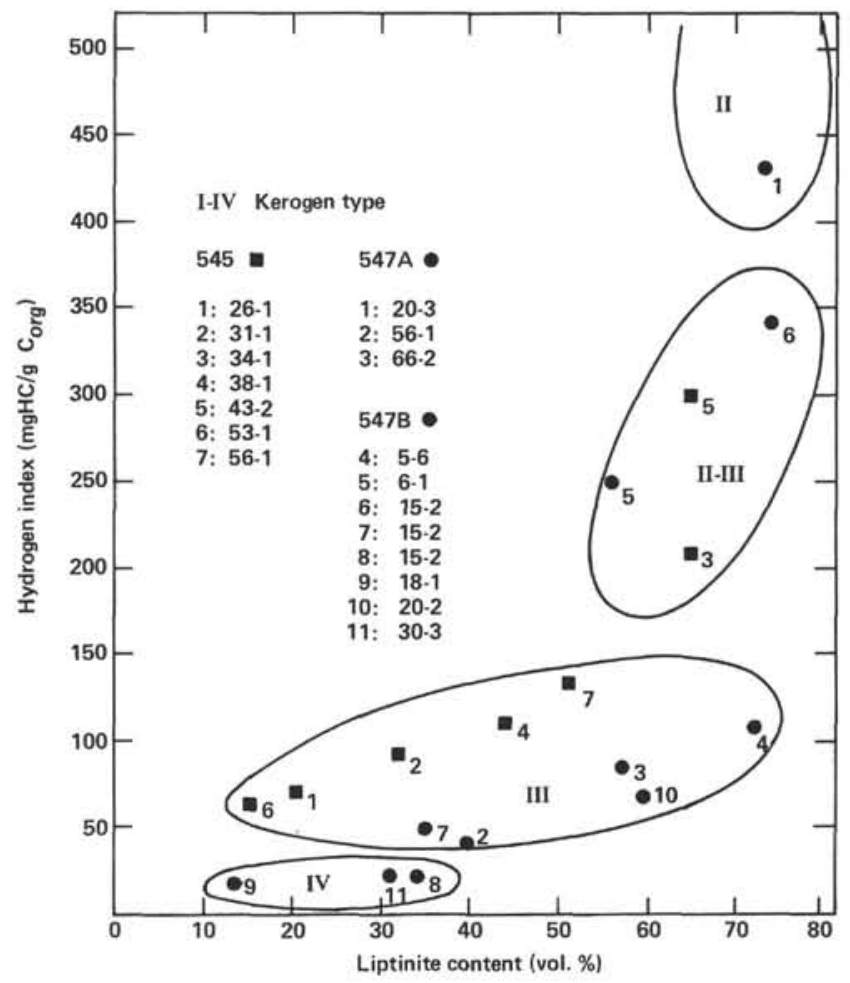

Figure 9. Hydrogen index (from Rock-Eval pyrolysis) versus liptinite content (from maceral analysis) diagram for DSDP Leg 79 sediments.

ple from Hole 547A that appears to be contaminated, all values are below or equal to $16 \mathrm{mg} / \mathrm{g} \mathrm{C}_{\text {org }}$. These values indicate low maturity of all samples and are consistent with the data for other deep-sea sediments (e.g., Rullkötter et al., 1981). A trend of increasing extract yields cannot be observed in any of the holes. There is, however, a slight increase of the hydrocarbon yields (nonaromatic plus aromatic) with depth in Holes 547A and 547B (Table 1).

\section{Nonaromatic Hydrocarbons}

The capillary column gas chromatograms in Figures 10-12 show the compositions of the nonaromatic hydrocarbons in the extracts of the Site 545, Hole 547A, and Hole 547B sediments. Constituents other than $n$-alkanes, pristane, and phytane were identified by combined GC/ MS based on relative retention times and mass spectral interpretation (Tables 4 and 5).

In the relatively organic-carbon-lean Miocene sediments from Site 545 the favored preservation of the more stable terrigenous organic matter is indicated by the high relative abundance of the long-chain $n$-alkanes with maxima at $n-\mathrm{C}_{31}$ (Sample 545-19-3, 75-95 cm; Fig. 10A) or $n-\mathrm{C}_{29}$ (Sample 545-26-1, 43-62 cm; Fig. 10B) and the low concentration of cyclic compounds, which in these samples are mainly hopanes of microbial origin (Ourisson et al., 1979).

The $n$-alkanes in the Cretaceous sediments from Site 545 are characterized by elevated concentrations of the $n$ - $\mathrm{C}_{17}$ and in some cases also the $n$ - $\mathrm{C}_{15}$ alkanes. These are usually regarded as biological markers indicating the 


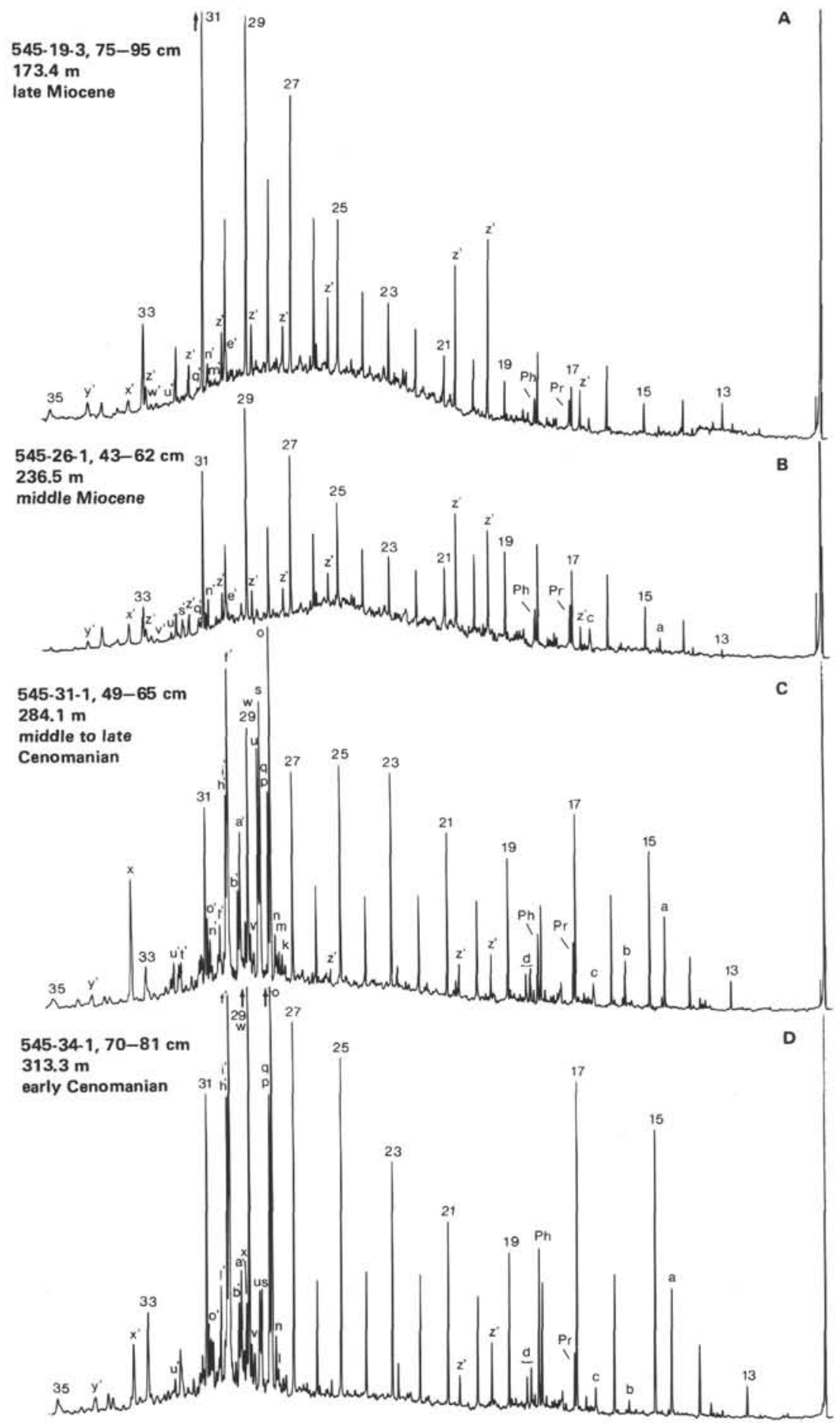

Figure 10. Capillary column gas chromatograms of the nonaromatic hydrocarbon fractions extracted from DSDP Site 545 sediments. $n$-Alkanes are marked by their carbon numbers. For lettered compounds see Table 4.

presence of phytoplankton remnants in the sediments (Blumer et al., 1971). Compared to the Miocene samples, the $n$-alkanes in the higher molecular weight range, derived from terrestrial higher plant waxes (Eglinton and Hamilton, 1963), have their maximum occasionally shifted to lower carbon numbers, for example, $n-\mathrm{C}_{27}$ (Sample $545-56-1,110-128 \mathrm{~cm}$; Fig. $10 \mathrm{H}$ ) or $n$ - $\mathrm{C}_{25}$ (Sample 545$43-2,130-140 \mathrm{~cm}$; Fig. 10F). This may either be due to variations in the higher plant populations contributing to the sediments or to partial microbial degradation of the wax alkanes (Simoneit et al., 1979, and references therein).

All Aptian through Cenomanian samples from Site 545 contain significant amounts of $\mathrm{C}_{16}$ and $\mathrm{C}_{18}$ to $\mathrm{C}_{20}$ isoprenoid hydrocarbons. In addition, 2-methylpentadecane occurs in elevated concentration in the late Albi- 


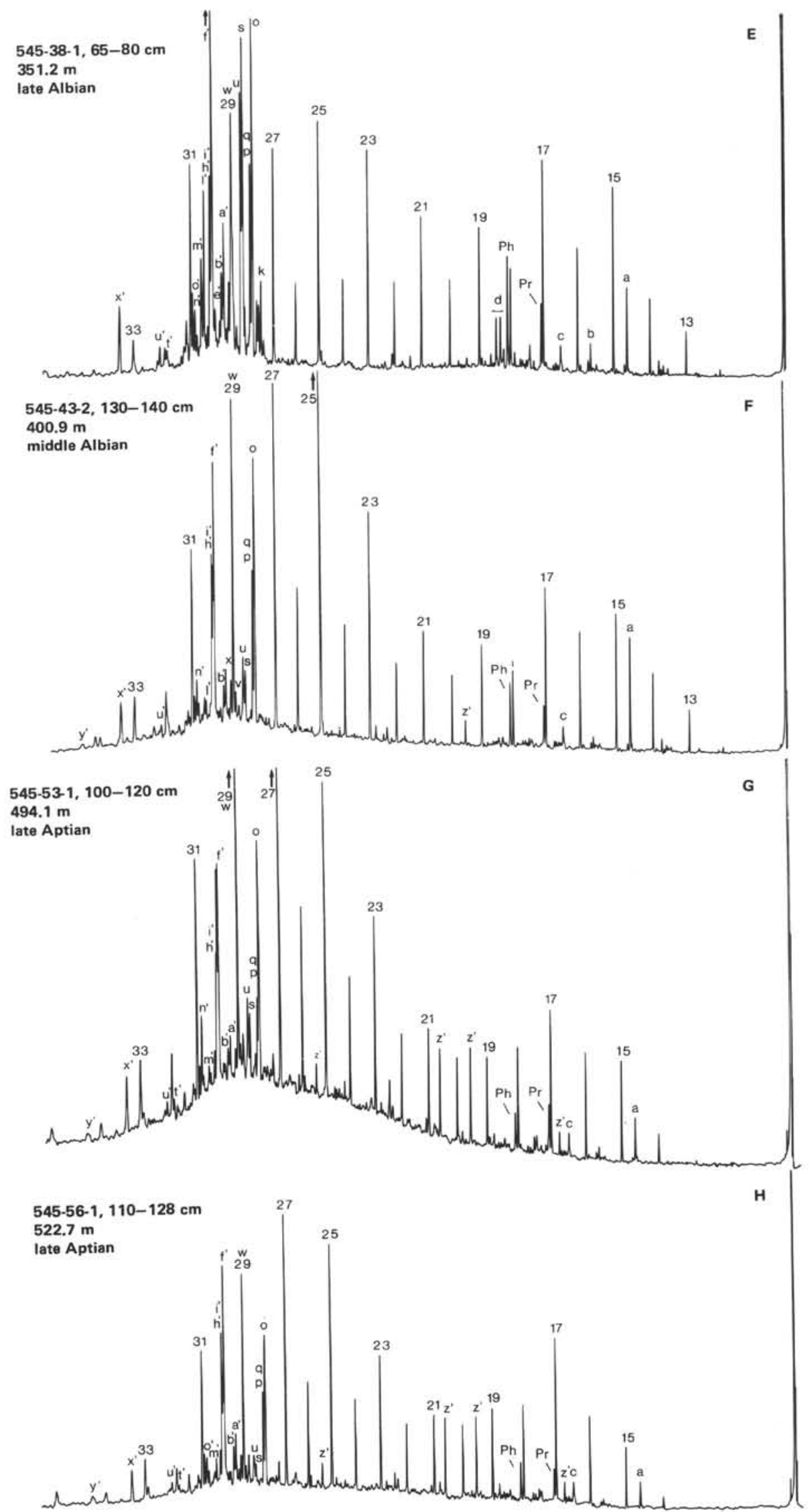

Figure 10. (Continued). 


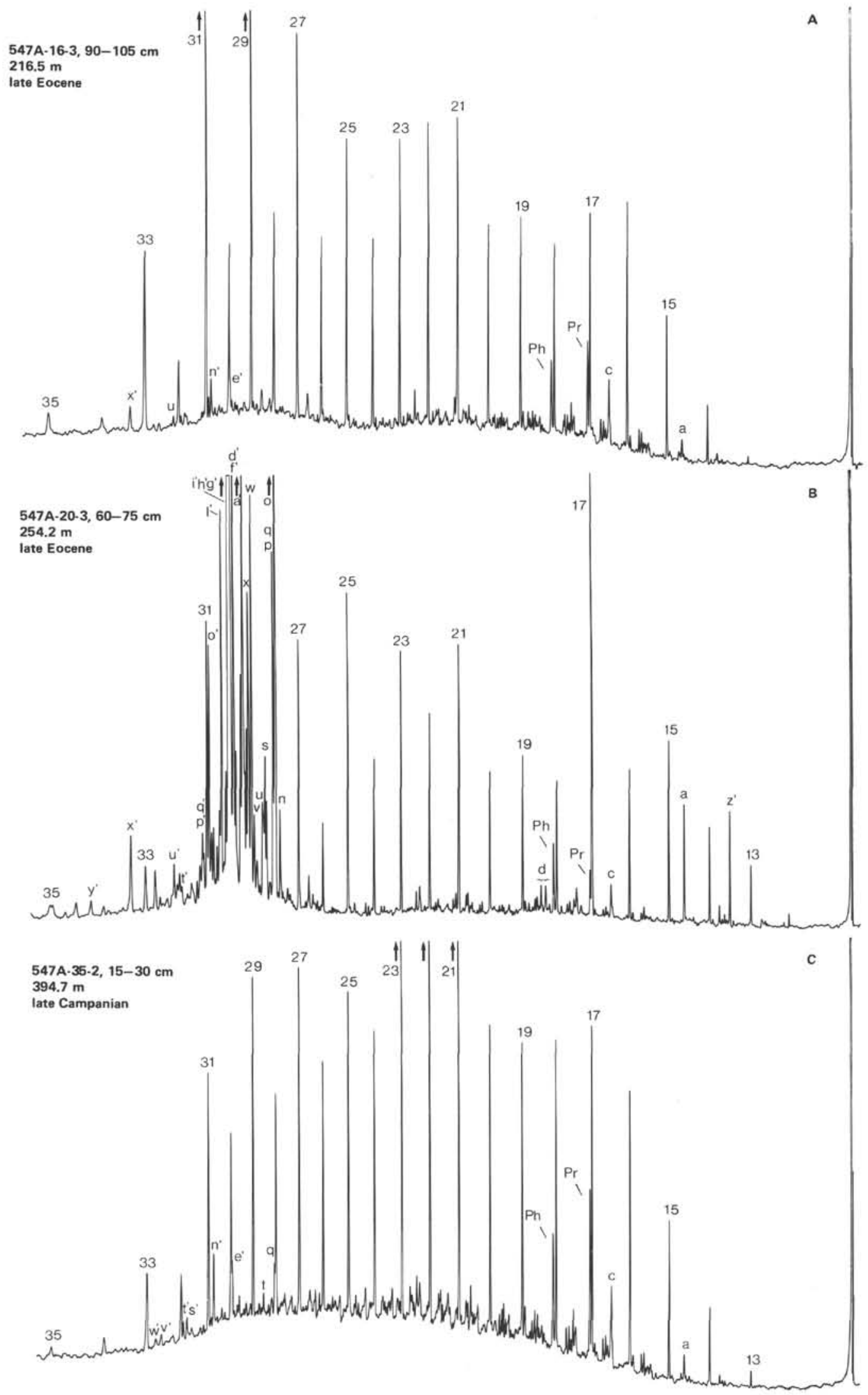

Figure 11. Capillary column gas chromatograms of the nonaromatic hydrocarbon fractions extracted from DSDP Site 547 sediments (except Jurassic). $n$-Alkanes are marked by their carbon numbers. For lettered compounds see Table 5. 

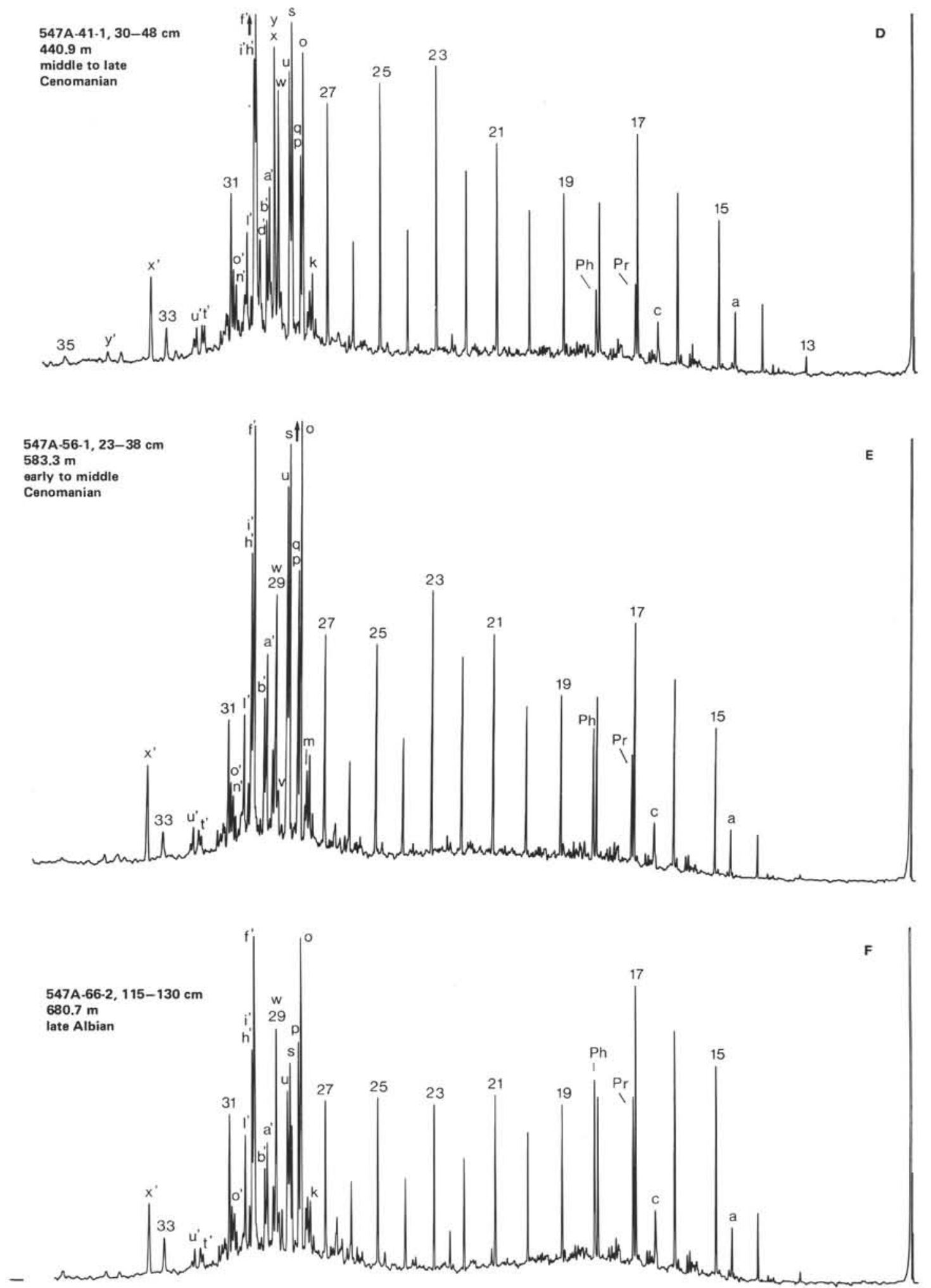

Figure 11. (Continued). 


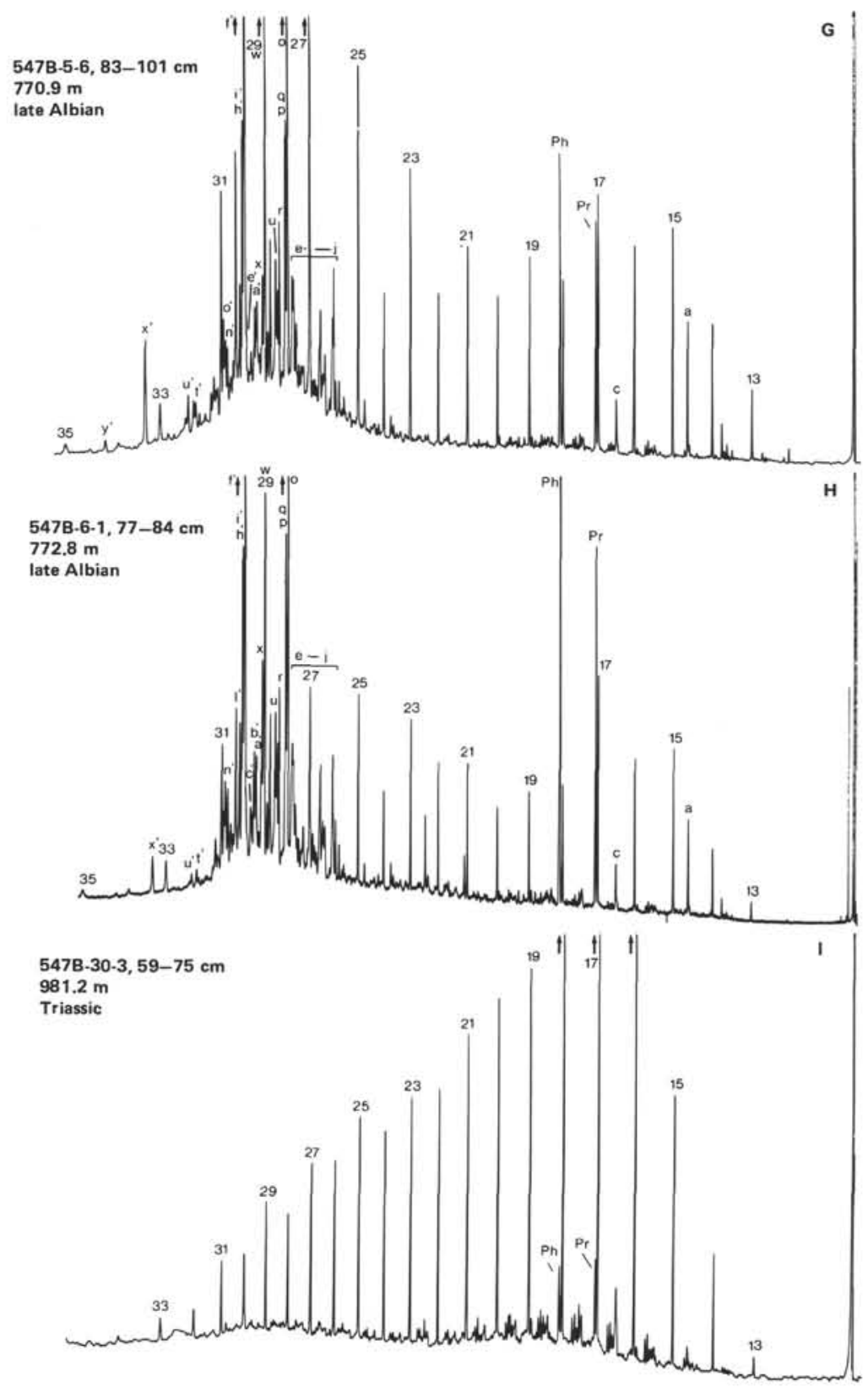

Figure 11. (Continued).

an and both Cenomanian sediments, which are also the only ones containing phytenes (Figs. 10C-10E). While the occurrence of phytenes in a certain depth interval is probably related to a specific diagenetic level, the significance of the presence of 2-methylpentadecane is not clear. Although phytane dominates over pristane in all samples except the late Aptian sediment from Section 545-53-1, this predominance reaches a high level only in the Cenomanian Sample 545-34-1, 70-81 cm (Fig. 10D).

Sterenes and steradienes (Table 4; cf. Appendix for compound structures) are the most prominent polycyclic nonaromatic hydrocarbons in all Cretaceous samples from Site 545. Ster-4-enes and ster-5-enes with 27 and 29 carbon atoms clearly dominate over the $\mathrm{C}_{28}$ homologs, and the ster-4-enes are slightly more abundant than the ster-5-ene isomers. Steradienes $\left(\Delta^{4,22}\right.$ and $\left.\Delta^{5,22}\right)$ also occur in the range of $\mathrm{C}_{27}$ to $\mathrm{C}_{29}$. The $\mathrm{C}_{28}$ and $\mathrm{C}_{29}$ compounds are found in considerably higher concentrations than the $\mathrm{C}_{27}$ steradienes that were only detected in samples containing 24-methyl-cholesta-4,22- and -5,22diene $\left(C_{28}\right)$ in very high abundance (Samples 545-31-1, $49-65 \mathrm{~cm}$ and 545-38-1, 65-80 cm; Figs. $10 \mathrm{C}$ and $10 \mathrm{E}$ ). Saturated regular $5 \beta(\mathrm{H})$ - and $5 \alpha(\mathrm{H})$-steranes are trace or minor components with a tendency of increasing concentration with depth relative to the steroid olefins. Other steroid hydrocarbons, for example, double-bond isomers, diasterenes, or diasteranes, could not be detected in the Site 545 sediments and thus will not exceed the trace level.

There is little variation in the distribution pattern of pentacyclic triterpenoid hydrocarbons within the series of Cretaceous sediments from Site 545. Hopanoids and two fernenes (Table 4), all supposedly derived from mi- 


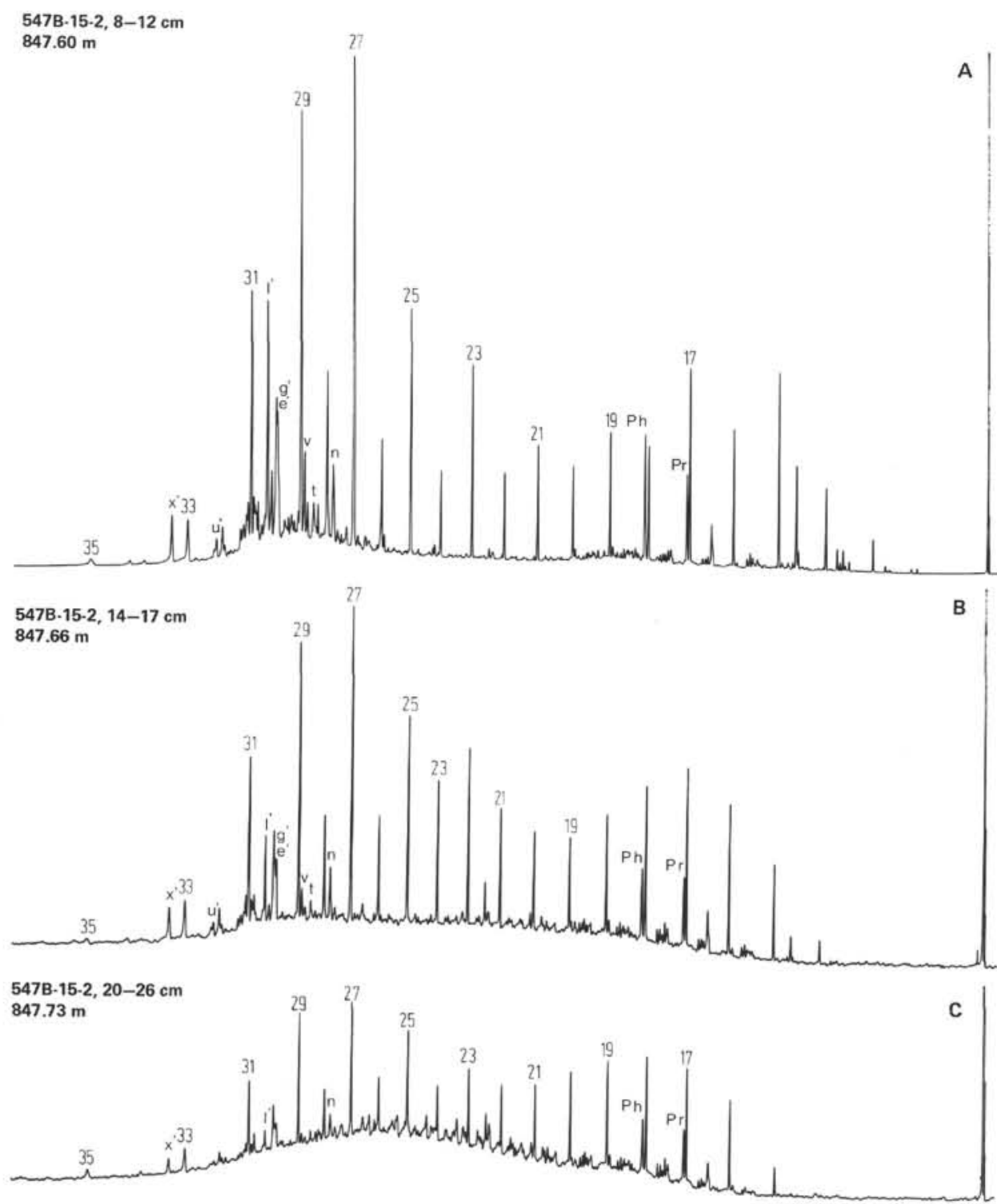

Figure 12. Capillary columns gas chromatograms of the nonaromatic hydrocarbon fractions extracted from Jurassic black shales in Subunit VIB, DSDP Hole 547B. For lettered compounds see Table 5.

croorganisms (Ourisson et al., 1979; Brassell et al., 1981), occur throughout, and $17 \beta(\mathrm{H})$-homohopane is the most abundant single species in each case. A $\mathrm{C}_{27}$-triterpene [tentatively identified as 22,29,30-trisnorneohop-13(18)ene] is present only in the Cenomanian and the late Albian sediments (Figs. 10C-10E).

The $n$-alkane distributions of the Hole 547A and Hole 547B samples are quite variable (Figs. 11 and 12), but in general show similar characteristics as those of the Site 545 samples. The organic-carbon-lean late Eocene (Sample 547A-16-3, 90-105 cm; Fig. 11A) and late Campanian sediments (Sample 547A-35-2, 15-30 cm; Fig. 11C) both have a broad $n$-alkane envelope with the odd-numbered, long-chain wax alkanes $\left(\mathrm{C}_{27}-\mathrm{C}_{33}\right)$ clearly recognizable but also with a significant proportion of alkanes between $n-\mathrm{C}_{20}$ and $n-\mathrm{C}_{25}$. The odd-over-even carbon number preference is less pronounced than in the more organic-carbon-rich sediments. This is typical of deep-sea sediments containing organic carbon close to a background level that usually partly consists of more mature reworked organic matter. Contamination of the organiccarbon-lean samples, however, cannot be fully ruled out. (The late Campanian sample is definitely contaminated as obvious from the total extract and pyrolysis data, but this contamination is not necessarily reflected in the nonaromatic hydrocarbon fraction.) The cyclic hydrocarbons with a high relative abundance of $17 \alpha(\mathrm{H})$ hopanes seem to support the idea of more mature reworked organic matter being present.

The late Eocene Sample 547A-20-3, 60-75 cm, a slump clast containing about $4 \%$ organic carbon, contains $n$-heptadecane $\left(\mathrm{C}_{17}\right)$ in very high abundance (Fig. 11B). This is consistent with a high proportion of marine organic matter in this sample. In this respect the concentration of phytane is surprisingly low. The presence of a terrigenous organic matter component still is indicated 


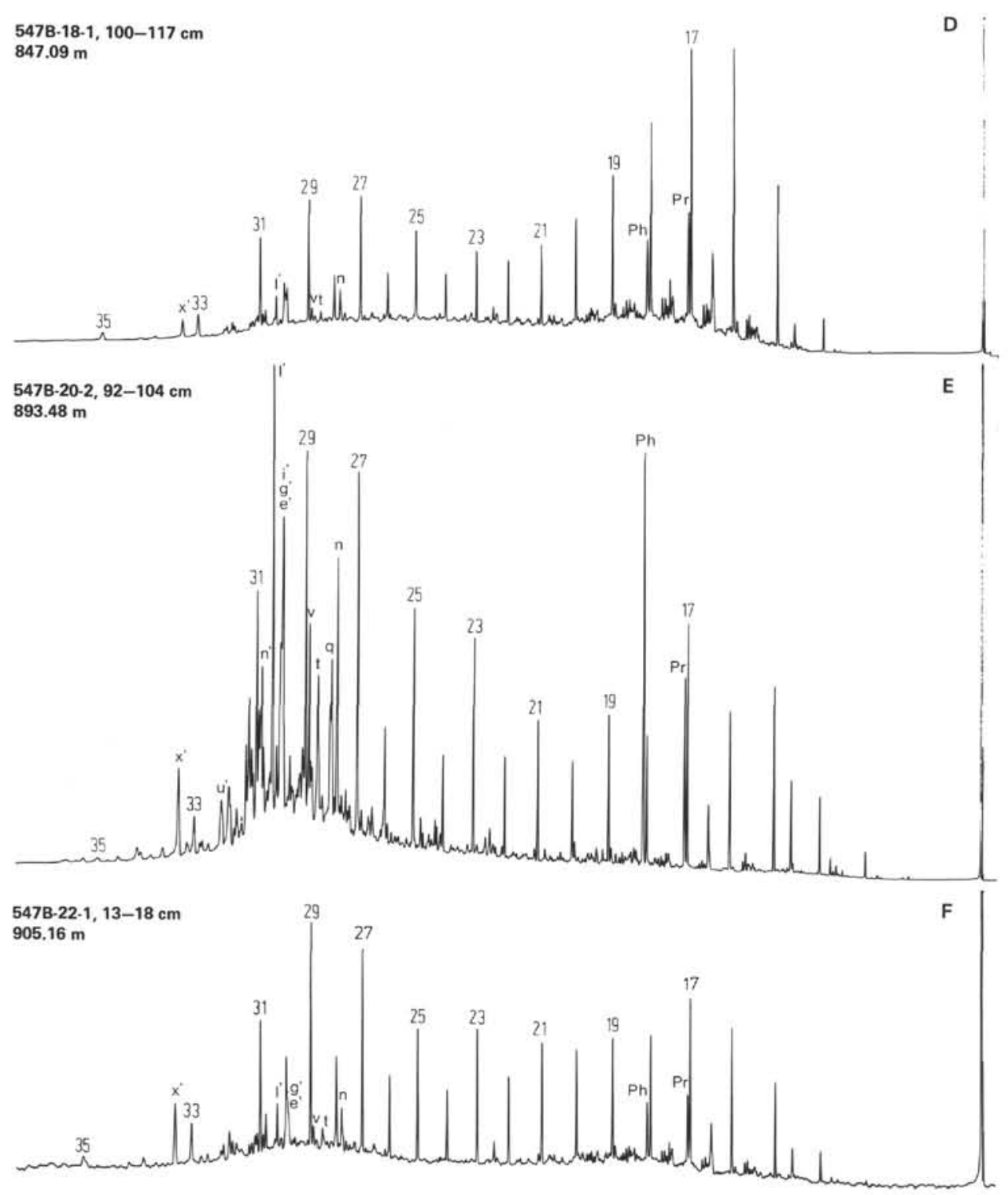

Figure 12. (Continued).

by the long-chain wax alkanes. The most abundant compounds of all in this sample, however, are polycyclic steroid and triterpenoid hydrocarbons. The dominance of $\mathrm{C}_{29}$ sterenes and steradienes over the $\mathrm{C}_{27}$ and $\mathrm{C}_{28}$ homologs, in contrast to the high $n$-heptadecane concentration, seems to indicate the presence of major amounts of terrigenous lipid material in this sample (Huang and Meinschein, 1979). All of the sterenes and steradienes show a clear predominance of the $\Delta^{4}$-isomers.

Among the triterpenoid hydrocarbons, the olefinic compounds 30-norhop-17(21)-ene, hop-17(21)-ene, and neohop-13(18)-ene clearly dominate over the saturated compounds in the hopane series. In addition, three $\mathrm{C}_{28}$ triterpenes were detected in significant concentrations. These compounds are not common in sediments, and their structures cannot be unambiguously inferred from their mass spectra, partly because two of them coelute with other major components under GC/MS conditions.
One of the compounds ( $\mathrm{d}^{\prime}$ in Fig. 11B and Table 5) based on the mass spectrum and the relative retention time appears to be identical with the $\mathrm{C}_{28}$ triterpene found in a deep-sea sediment from the Guaymas Basin in the Gulf of California (Rullkötter, von der Dick, et al., 1982). There it was speculated that this compound was an olefinic precursor of 28,30 -bisnor- $17 \alpha(\mathrm{H})$-hopane that cooccurred in the Guaymas Basin sediment and meanwhile has been found in many sediments worldwide, often in unusually high concentration (cf. Rullkötter, Leythaeuser, et al., 1982, for an overview). This saturated bisnorhopane, however, could not be detected in the Eocene sample from Hole 547A. A series of four $\mathrm{C}_{28}$ triterpenes has been reported for a Cretaceous sediment from the Hess Rise in the Pacific Ocean (Comet et al., 1981), but no structures were proposed.

The two Cenomanian sediments from Hole 547A strongly resemble each other in their nonaromatic hy- 
Table 4. Isoprenoid, steroid, and triterpenoid hydrocarbons detected in the nonaromatic hydrocarbon fractions of sediments from DSDP Site 545 .

\begin{tabular}{|c|c|c|c|c|c|c|c|c|c|c|}
\hline & \multirow[b]{2}{*}{ Compound } & \multirow[b]{2}{*}{ Structure } & \multicolumn{8}{|c|}{ Core-Section $^{\mathrm{a}}$} \\
\hline & & & 19-3 & $26-1$ & $31-1$ & $34-1$ & $38-1$ & 43-2 & 53-1 & $56-1$ \\
\hline a & $\begin{array}{l}2,6,10 \text {-trimethyl- } \\
\text { tridecane }\end{array}$ & I & & + & ++ & ++ & ++ & ++ & + & + \\
\hline b & 2-methylpentadecane & II & tr & tr & ++ & + & + & tr & tr & tr \\
\hline c & norpristane & $\mathrm{III}, \mathrm{R}=\mathrm{H}$ & + & + & + & + & + & + & + & + \\
\hline $\mathrm{pr}$ & pristane & III, $\mathrm{R}=\mathrm{CH}_{3}$ & + & ++ & ++ & + & ++ & + & + & + \\
\hline $\begin{array}{l}\text { ph } \\
\text { d }\end{array}$ & $\begin{array}{l}\text { phytane } \\
\text { phytadienes }\end{array}$ & $\mathrm{III}, \mathrm{R}=\mathrm{C}_{2} \mathrm{H}_{5}$ & + & ++ & $\begin{array}{c}++ \\
+\end{array}$ & $\begin{array}{c}++ \\
+\end{array}$ & $\begin{array}{c}++ \\
+\end{array}$ & $\stackrel{++}{\text { tr }}$ & + & + \\
\hline $\mathrm{k}$ & cholesta-4,22-diene & $\mathrm{V}, \mathbf{R}=\mathbf{H}$ & & & + & & + & & & \\
\hline 1 & $5 \beta(\mathrm{H})$-cholestane & $\mathrm{VI}, \mathrm{R}=\mathrm{H}$ & & & tr & + & tr & tr & tr & tr \\
\hline $\mathrm{m}$ & cholesta-5,22-diene & VII, $R=H$ & & & + & & + & & & \\
\hline $\mathrm{n}$ & $\begin{array}{l}\text { 22,29,30-trisnorneo- } \\
\text { hop-13(18)-ene }\end{array}$ & VIII, $R=H$ & & & + & + & + & & & \\
\hline o & cholest-4-ene & $\begin{array}{l}\mathrm{IX}, \mathrm{R}=\mathrm{H} \\
\mathrm{X}=\mathrm{P}=\mathrm{H}\end{array}$ & & & +++ & +++ & +++ & ++ & + & ++ \\
\hline $\mathrm{p}$ & cholest-5-ene & $\begin{array}{l}X, R=H \\
X I R=H\end{array}$ & & & ++ & $\begin{array}{l}++ \\
+\end{array}$ & ++ & ++ & + & ++ \\
\hline$q$ & $\begin{array}{l}5 \alpha(\mathrm{H}) \text {-cholestane } \\
22,29,30 \text {-trisnorneo- } \\
\text { hopane }\end{array}$ & $\begin{array}{l}\mathrm{XI}, \mathrm{R}=\mathrm{H} \\
\mathrm{XII}\end{array}$ & tr & tr & $\begin{array}{l}+ \\
\text { tr }\end{array}$ & $\begin{array}{l}+ \\
\text { tr }\end{array}$ & $\stackrel{+}{t}$ & + & $\operatorname{tr}$ & $\begin{array}{l}+ \\
\mathrm{tr}\end{array}$ \\
\hline s & $\begin{array}{l}\text { 24-methylcholesta- } \\
\text { 4,22-diene }\end{array}$ & $\mathrm{V}, \mathrm{R}=\mathrm{CH}_{3}$ & & & +++ & ++ & +++ & + & + & + \\
\hline $\mathrm{t}$ & $\begin{array}{l}\text { 22,29,30-trisnor- } \\
17 \alpha(\mathrm{H}) \text {-hopane }\end{array}$ & $\mathrm{XIII}, \mathrm{R}=\mathrm{H}$ & tr & tr & + & + & + & + & + & + \\
\hline $\mathrm{u}$ & $\begin{array}{l}\text { 24-methylcholesta- } \\
\text { 5,22-diene }\end{array}$ & $\mathrm{VII}, \mathbf{R}=\mathrm{CH}_{3}$ & & & +++ & ++ & +++ & + & + & + \\
\hline & 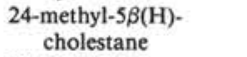 & $\mathrm{VI}, \mathrm{R}=\mathrm{CH}_{3}$ & & & $\operatorname{tr}$ & tr & tr & $\operatorname{tr}$ & & \\
\hline v & $\begin{array}{l}22,29,30 \text {-trisnor- } \\
17 \beta(\mathrm{H}) \text {-hopane }\end{array}$ & $\mathrm{XIV}, \mathrm{R}=\mathrm{H}$ & & & + & + & + & + & tr & + \\
\hline w & $\begin{array}{l}\text { 24-methylcholest-4- } \\
\text { ene }\end{array}$ & $\mathrm{IX}, \mathrm{R}=\mathrm{CH}_{3}$ & & + & + & + & + & tr & + & \\
\hline $\mathrm{x}$ & $\begin{array}{l}\text { 24-methylcholest-5- } \\
\text { ene }\end{array}$ & $\mathrm{X}, \mathrm{R}=\mathrm{CH}_{3}$ & & & + & + & + & + & $\operatorname{tr}$ & + \\
\hline $\mathrm{z}$ & $\begin{array}{l}\text { 24-methyl- } 5 \alpha(\mathrm{H}) \text { - } \\
\text { cholestane }\end{array}$ & $\mathrm{XI}, \mathrm{R}=\mathrm{CH}_{3}$ & tr & tr & tr & + & tr & tr & & \\
\hline$a^{\prime}$ & $\begin{array}{l}\text { 24-ethylcholesta-4,22- } \\
\text { diene }\end{array}$ & $\mathrm{V}, \mathrm{R}=\mathrm{C}_{2} \mathrm{H}_{5}$ & & & ++ & ++ & ++ & + & + & + \\
\hline$b^{\prime}$ & $\begin{array}{l}\text { 24-ethylcholesta-5,22- } \\
\text { diene }\end{array}$ & VII, $\mathrm{R}=\mathrm{C}_{2} \mathrm{H}_{5}$ & & & ++ & ++ & + & + & + & + \\
\hline$c^{\prime}$ & $\begin{array}{l}\text { 24-ethyl- } 5 \beta(\mathrm{H}) \text {-choles- } \\
\text { tane }\end{array}$ & $\mathrm{VI}, \mathrm{R}=\mathrm{C}_{2} \mathrm{H}_{5}$ & & & tr & + & tr & tr & tr & tr \\
\hline $\begin{array}{l}e^{\prime} \\
f^{\prime}\end{array}$ & $\begin{array}{l}\text { 30-nor-17 } \alpha(\mathrm{H}) \text {-hopane } \\
\text { 24-ethylcholest-4-ene }\end{array}$ & $\begin{array}{l}\mathrm{XIII}, \mathrm{R}=\mathrm{C}_{2} \mathrm{H}_{5} \\
\mathrm{IX}, \mathrm{R}=\mathrm{C}_{2} \mathrm{H}_{5}\end{array}$ & + & + & $\begin{array}{l}+ \\
++\end{array}$ & $\begin{array}{l}+ \\
++\end{array}$ & $\begin{array}{l}+ \\
+++\end{array}$ & $\begin{array}{l}+ \\
++\end{array}$ & $\begin{array}{l}+ \\
++\end{array}$ & $\stackrel{+}{++}$ \\
\hline $\mathrm{g}^{\prime}$ & 30-norhop-17(21)-ene & $\mathrm{XV}, \mathrm{R}=\mathrm{C}_{2} \mathrm{H}_{5}$ & & & tr & tr & + & tr & & tr \\
\hline$h^{\prime}$ & 24-ethylcholest-5-ene & $\mathrm{X}, \mathrm{R}=\mathrm{C}_{2} \mathrm{H}_{5}$ & & & ++ & ++ & ++ & ++ & ++ & +++ \\
\hline $\mathrm{i}^{\prime}$ & $\begin{array}{l}\text { 24-ethyl-5 } \alpha(\mathrm{H}) \text {-choles- } \\
\text { tane }\end{array}$ & $\mathrm{XI}, \mathrm{R}=\mathrm{C}_{2} \mathrm{H}_{5}$ & tr & tr & + & + & + & + & + & + \\
\hline $\begin{array}{l}l^{\prime} \\
m^{\prime}\end{array}$ & hop-17(21)-ene & $\mathrm{XV}, \mathrm{R}=\mathrm{CH}\left(\mathrm{CH}_{3}\right)_{2}$ & & & + & ++ & ++ & + & + & + \\
\hline $\mathrm{m}^{\prime}$ & $\begin{array}{l}\text { 30-normoretane (+ } \\
\text { unknown } C_{29} \\
\text { triterpene) }\end{array}$ & $\mathrm{XVI}, \mathrm{R}=\mathrm{H}$ & tr & tr & + & + & + & + & + & + \\
\hline $\mathrm{n}^{\prime}$ & $17 \alpha(\mathrm{H})$-hopane & $\begin{array}{l}\mathrm{XIII}, \mathrm{R}=\mathrm{CH}\left(\mathrm{CH}_{3}\right)_{2} \\
\text { VIII, } \mathrm{R}=\mathrm{CH}\left(\mathrm{CH}_{3}\right)_{2}\end{array}$ & + & + & $\begin{array}{l}+ \\
++\end{array}$ & $\begin{array}{l}+ \\
+\end{array}$ & $\begin{array}{l}+ \\
+\end{array}$ & + & $\begin{array}{c}++ \\
+\end{array}$ & + \\
\hline $\begin{array}{l}\mathrm{o}^{\prime} \\
\mathrm{p}^{\prime}\end{array}$ & $\begin{array}{l}\text { neohop-13(18)-ene } \\
\text { fern-8-ene }\end{array}$ & $\begin{array}{l}\text { VIII, R }=\mathrm{CH}\left(\mathrm{CH}_{3}\right)_{2} \\
\text { XVII }\end{array}$ & & & $\mathrm{tr}^{+}$ & $\begin{array}{l}+ \\
+\end{array}$ & $\begin{array}{l}+ \\
+\end{array}$ & $\begin{array}{l}+ \\
\operatorname{tr}\end{array}$ & $\begin{array}{l}+ \\
\text { tr }\end{array}$ & $\begin{array}{l}+ \\
\text { tr }\end{array}$ \\
\hline$q^{\prime}$ & 30-nor-17 $\beta(\mathrm{H})$-hopane & $\mathrm{XIV}, \mathrm{R}=\mathrm{C}_{2} \mathrm{H}_{5}$ & tr & tr & + & + & + & + & + & + \\
\hline & moretane & $\mathrm{XVI}, \mathrm{R}=\mathrm{CH}_{3}$ & tr & + & + & + & + & tr & tr & ts \\
\hline $\begin{array}{l}c^{\prime \prime} \\
s^{\prime}\end{array}$ & fern-9(11)-ene & XVIII & & tr & tr & tr & tr & tr & & \\
\hline $\mathbf{s}^{\prime}$ & $\begin{array}{l}17 \alpha(\mathrm{H}) \text {-homohopane } \\
\text { (22S) }\end{array}$ & $\mathrm{XIII}, \mathrm{R}=\mathrm{CH}\left(\mathrm{CH}_{3}\right) \mathrm{C}_{2} \mathrm{H}_{5}$ & tr & + & $\operatorname{tr}$ & tr & tr & tr & tr & tr \\
\hline$t^{\prime}$ & $\begin{array}{l}17 \alpha(\mathrm{H}) \text {-homohopane } \\
(22 \mathrm{R})\end{array}$ & $\mathrm{XIII}, \mathrm{R}=\mathrm{CH}\left(\mathrm{CH}_{3}\right) \mathrm{C}_{2} \mathrm{H}_{5}$ & $\operatorname{tr}$ & tr & + & + & + & + & tr & + \\
\hline $\mathbf{u}^{\prime}$ & $\begin{array}{l}17 \beta(\mathrm{H}) \text {-hopane } \\
\text { homomoretane }\end{array}$ & $\begin{array}{l}\mathrm{XIV}, \mathrm{R}=\mathrm{CH}\left(\mathrm{CH}_{3}\right)_{2} \\
\mathrm{XVI}, \mathrm{R}=\mathrm{C}_{2} \mathrm{H}_{5}\end{array}$ & $\operatorname{tr}$ & + & $\begin{array}{l}+ \\
+\end{array}$ & $\begin{array}{l}+ \\
\text { tr }\end{array}$ & $\begin{array}{l}+ \\
\mathrm{tr}\end{array}$ & + & + & + \\
\hline $\mathbf{v}^{\prime}$ & $\begin{array}{l}\text { 17 } \alpha(\mathrm{H}) \text {-bishomoho- } \\
\text { pane (22S) }\end{array}$ & $\mathrm{XIII}, \mathrm{R}=\mathrm{CH}\left(\mathrm{CH}_{3}\right) \mathrm{C}_{3} \mathrm{H}_{7}$ & tr & tr & & & & & & \\
\hline $\mathbf{w}^{\prime}$ & $\begin{array}{l}17 \alpha(\mathrm{H}) \text {-bishomoho- } \\
\text { pane (22R) }\end{array}$ & $\mathrm{XIII}, \mathrm{R}=\mathrm{CH}\left(\mathrm{CH}_{3}\right) \mathrm{C}_{3} \mathrm{H}_{7}$ & $\operatorname{tr}$ & tr & & & & & & \\
\hline$x^{\prime}$ & $17 \beta(\mathrm{H})$-homohopane & 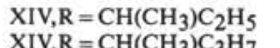 & + & + & ++ & ++ & ++ & + & ++ & + \\
\hline $\mathbf{y}^{\prime}$ & $\begin{array}{l}17 \beta(\mathrm{H}) \text {-bishomoho- } \\
\text { pane } \\
\text { contaminants (e.g., pht }\end{array}$ & $\begin{array}{l}\mathrm{XIV}, \mathrm{R}=\mathrm{CH}\left(\mathrm{CH}_{3}\right) \mathrm{C}_{3} \mathrm{H}_{7} \\
\text { alate esters, column bleed) }\end{array}$ & + & + & + & + & & tr & tr & \\
\hline
\end{tabular}

Note: Compounds are listed in order of elution from the GC column (cf. Fig. 10). Estimated abundances: $+++=$ major, ++ $=$ intermediate, $+=$ minor, $\mathrm{tr}=$ trace. Sample intervals as in Table 1 .

drocarbon composition (Figs. 11D and 11E) with the only exception that the shallower sediment contains the three $\mathrm{C}_{28}$ triterpenes also found in the Eocene slump sample. Shipboard paleontology revealed a complex mixture of mainly Late Cretaceous and early Tertiary fossils in the Eocene slump sequence with occasional occurrence of mid-Cretaceous species. The organic geochemical results, that is, the co-occurrence of the rare $\mathrm{C}_{28}$ triterpenes in the Eocene and the Cenomanian, seem to indicate significant mid-Cretaceous contribution to the 
Table 5. Isoprenoid, steroid, and triterpenoid hydrocarbons detected in the nonaromatic hydrocarbon fractions of sediments from DSDP Holes 547A and 547B.

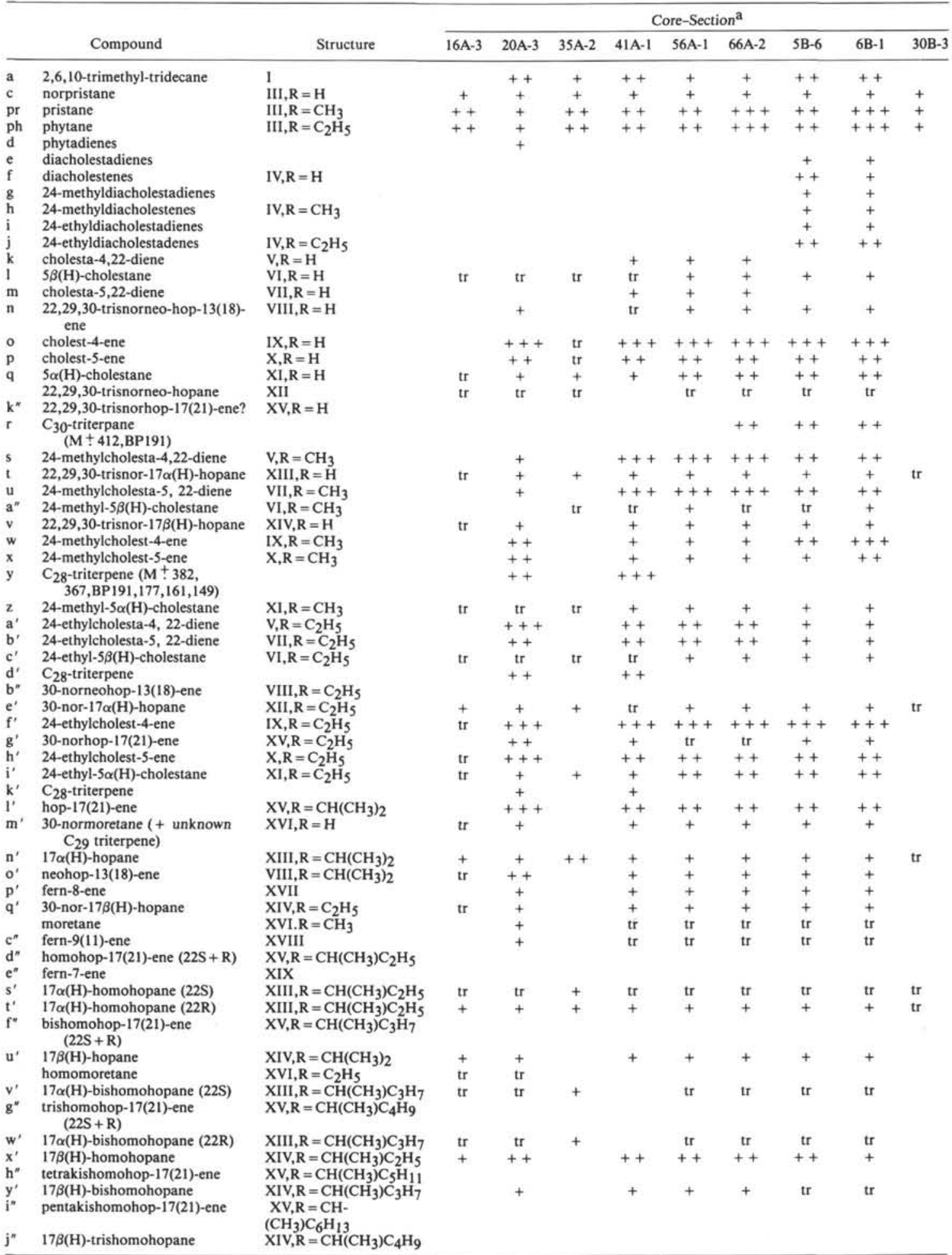

Note: Compounds are listed in order of elution from the GC column (cf. Figs. 11-12). Estimated abundances: $+++=$ major, $++=$ intermediate, $+=$ minor, $\mathrm{tr}=$ trace. Sample intervals as in Table 1.

slump sequence. The $n$-alkane distributions of the Cenomanian sediments reflect a mixture of marine $\left(n-\mathrm{C}_{17}\right)$ and terrigenous organic matter (long-chain $n$-alkanes) with noticeable microbial action resulting in an $n$-alkane maximum at $n-\mathrm{C}_{23}$. High sterene and steradiene concen- trations may be taken as an indication of good preservation conditions for organic matter during deposition.

Among the three Albian sediments investigated, Sample 547B-5-6, 83-101 cm (Fig. 11G) has the highest relative abundance of long-chain $n$-alkanes consistent with 
more than $85 \%$ terrigenous organic matter content as determined by kerogen microscopy. All Albian samples contain an unknown $\mathrm{C}_{30}$ triterpane eluting just before the $\mathrm{C}_{28}$ steradienes ( $\mathrm{r}$ in Figs. $11 \mathrm{~F}-\mathrm{H}$ ). Otherwise the shallowest Albian sample (547A-66-2, 115-130 cm) resembles the Cenomanian sediments. The two deeper Albian samples contain diasterenes and diasteradienes in significant amounts. The same compounds also may be present in the shallower sediments in very small concentrations, but they were not identified unambiguously. The occurrence of these compounds in higher concentration in the deeper Albian sediments can be explained as a diagenetic phenomenon rather than a difference in type of organic matter. Sample 547B-6-1, 77-84 cm (Fig. $11 \mathrm{H}$ ) shows remarkably high pristane, phytane, and steroid hydrocarbon concentrations indicating an oxygen-depleted depositional environment and favorable conditions for organic matter preservation.

The capillary gas chromatograms of the nonaromatic hydrocarbon fractions of six sediment samples from the Jurassic black shale sequence of Hole 547B are shown in Figure 12. The sample series in Figures 12A-C represent the gradual change from the main black shale facies (Sample 547B-15-2, 8-12 cm; Fig. 12A) into the organic-carbon-lean matrix sediment. The other three samples are from deeper black shale intervals and include two facies A samples (Figs. 12D and 12F) and a facies B sample (Fig. 12E). Long-chain $n$-alkanes derived from higher plant waxes (Eglinton and Hamilton, 1963) are significant in each nonaromatic hydrocarbon fraction. The maximum is at $n-C_{27}$ or $n-C_{29}$, and the clear predominance of the odd-carbon-number species indicates a low maturity of the organic matter. All $n$-alkane distributions are bimodal, however, with a second maximum at $n-\mathrm{C}_{17}$. An odd-over-even carbon-number predominance in this range is only seen in Samples 547B-15-2, 8-12 cm (Fig. 12A) and 547B-20-2, 92-104 cm (Fig. 12E), where the marine lipid component may contribute to these shorter-chain $n$-alkanes. In all cases, however, there seems to be a contribution from more mature, recycled organic matter to this $n$-alkane range. This may be concluded from the absence of a carbon number preference around $n-\mathrm{C}_{17}$ in those samples containing only small amounts of primary organic matter (e.g., Samples 547B-15-2, 20-26 cm; 547B-18-1, 100-117 cm).

Phytane clearly dominates over pristane in the more liptinite-rich Samples 547B-15-2, 8-12 cm and 547B-20-2, 92-104 cm, indicating environmental conditions more favorable for the preservation of labile, lipid-rich organic matter (Didyk et al., 1978). In contrast to the organofacies interpretation from kerogen microscopy, the phytane dominance is more pronounced in Sample 547B20-2, 92-104 cm than in Sample 547B-15-2, 8-12 cm. The other four samples show a nearly equal abundance of pristane and phytane or a slight pristane predominance (Fig. 12).

The cyclic nonaromatic hydrocarbon compositions in the more organic-carbon-lean samples resemble each other, and they are similar, but reduced in abundance, to that in Sample 547B-15-2, 8-12 cm (Fig. 12A). Thus, only the latter sample will be discussed in more detail and compared to Sample 547B-20-2, 92-104 cm, which has a somewhat different cyclic nonaromatic hydrocarbon composition. Mass chromatograms of the most important compound series for both samples are shown in Figure 13. Triterpenoids-represented by fragments $\mathrm{m} / \mathrm{z}$ 191 (hopanoids), 231 (mostly hop-17(21)-enes), and 243 (fernenes)-are the most abundant cyclic nonaromatic hydrocarbons in each case, but differences in the distribution patterns are obvious. Unsaturated triterpenes are common in both samples, most of them are hop-17(21)enes found as $\mathrm{C}_{27}$ and $\mathrm{C}_{29}-\mathrm{C}_{33}$ (Samples 547B-15-2, 8-12 cm) or $\mathrm{C}_{35}$ homologs (547B-20-2, 92-104 cm). Neohop-13(18)-enes are present as $\mathrm{C}_{27}, \mathrm{C}_{29}$, and $\mathrm{C}_{30}$ homologs, only. This supports the interpretation of Brassell et al. (1980) that neohop-13(18)-enes and hop-17(21)-enes are not diagenetically related to each other, because they found in deep-sea sediments from the Japan Trench that neo-hop-13(18)-ene concentrations do not follow the diagenetic transformation trends expected from other biological marker parameters. Three fernene isomers are minor components in both black shale samples investigated in detail by GC/MS (Fig. 13).

A major difference between Samples 547B-15-2, 8-12 $\mathrm{cm}$ and 547B-20-2, 92-104 cm can be found in the isomer distribution of saturated triterpanes of the hopane type. It is well known that initially formed $17 \beta(\mathrm{H})$-hopanes still bearing the biogenic configuration at $\mathrm{C}-17$ undergo isomerization to the thermo-dynamically more stable $17 \alpha(\mathrm{H})$-hopanes during the late diagenesis and early catagenesis stages, in addition to isomerization in the sidechain (Seifert and Moldowan, 1980). Because it has been noted by kerogen microscopy, Rock-Eval pyrolysis, and the presence of unsaturated hydrocarbons in the extracts of both the samples discussed here that the organic matter is immature, a strong dominance of $17 \beta(\mathrm{H})$-hopanes would be expected together with little difference between the samples since they are separated only by a few tens of meters. Both samples, however, contain relatively high concentrations of $17 \alpha(\mathrm{H})$-hopanes. The $\mathrm{C}_{27}$ and $\mathrm{C}_{30}$ homologs exceed the concentrations of the corresponding $17 \beta(\mathrm{H})$-isomers in Sample 547B-20-2, 92-104 cm, whereas $17 \alpha(\mathrm{H})$-hopanes are slightly less abundant in Sample 547B-15-2, 8-12 cm. The high relative concentration of $17 \alpha(\mathrm{H})$-hopanes in both samples strongly suggests the presence of reworked, prematured organic matter, and from the $17 \beta(\mathrm{H}) / 17 \alpha(\mathrm{H})$-hopane ratios it can be concluded that the contribution of this type of material was stronger to the deeper sample.

Steroid hydrocarbons are less abundant than triterpenoids in the black shale samples. They mainly consist of saturated $5 \alpha(\mathrm{H})$ - and $5 \beta(\mathrm{H})$-steranes with 27 to 29 carbon atoms and with the $\mathrm{C}_{29}$ homolog as the most abundant member in this series. This again is an indication of a dominating terrigenous organic matter component in the black shales (Huang and Meinschein, 1979).

The sediment sample from Section 547B-30-3, which probably is of Triassic age, has a nonaromatic hydrocarbon composition (Fig. $11 \mathrm{H}$ ) in which the $n$-alkane distribution reflects the terrigenous organic matter content 
A

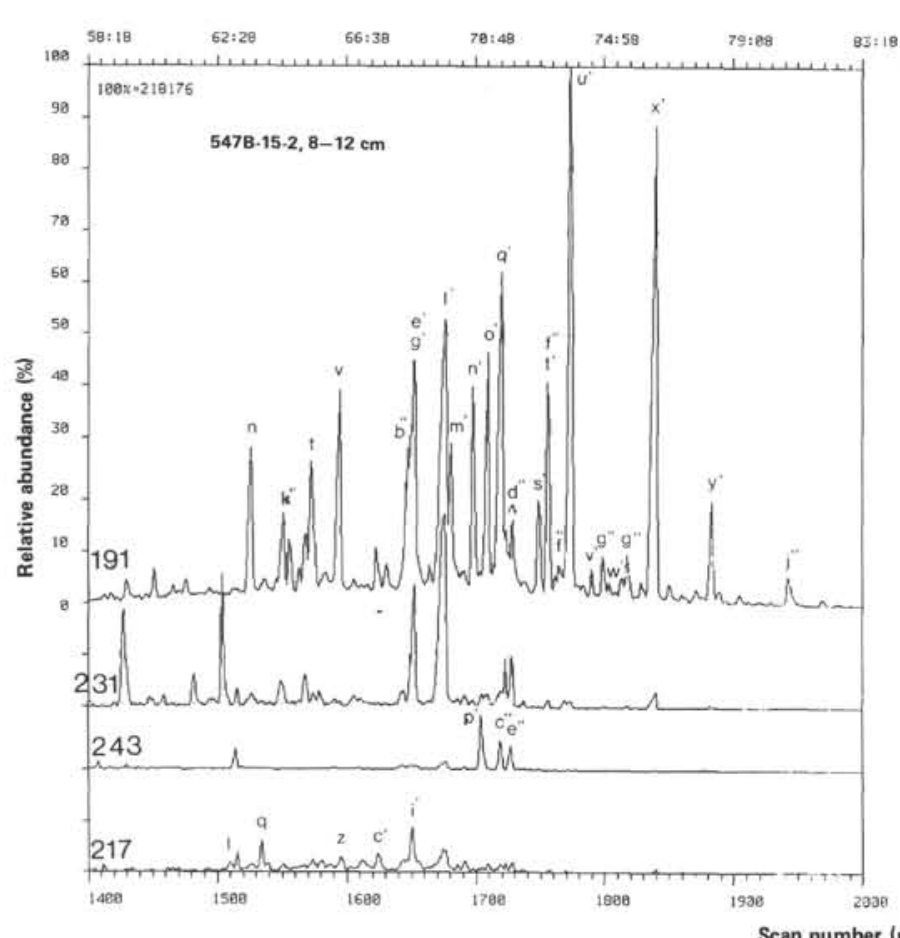

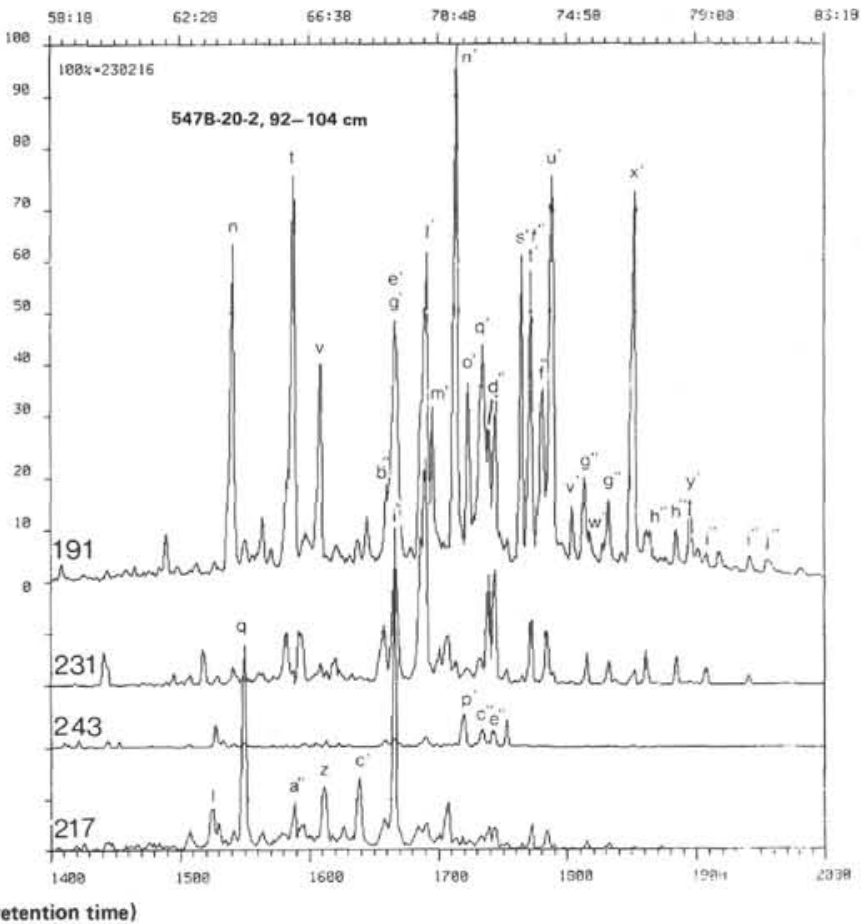

Figure 13. Mass fragmentograms of selected key ions of biological marker compounds in the nonaromatic hydrocarbon fractions of the black shale Samples 547B-15-2, 8-12 cm (A) and 547B-20-2, 92-104 cm (B) (m/z 191: terpenoids, $\mathrm{m} / \mathrm{z} 231$ : hop-17(21)-enes, $\mathrm{m} / \mathrm{z}$ 243: fernenes, $\mathrm{m} / \mathrm{z}$ 217: steranes).

as well as the higher maturity relative to the younger sediments. There is only a subordinate content of cyclic nonaromatic hydrocarbons in this sample.

\section{Aromatic Hydrocarbons}

The aromatic hydrocarbon composition in the extracts of the Leg 79 sediments was only investigated for a number of selected, mostly the more organic-carbon-rich, samples (excluding the Jurassic black shales). In most cases, mono-aromatic steroid hydrocarbons and hopanederived aromatic hydrocarbons with one to four aromatized rings are the dominant compound classes. As an example for Site 545, the partial total ion chromatograms from GC/MS analysis of Samples 545-34-1, 76-81 cm (middle Cenomanian) and 545-38-1, 65-80 cm (late Albian) are shown in Figure 14. The late Cenomanian sediment from Section 545-31-1 has an aromatic hydrocarbon composition very similar to those shown in Figure 14, whereas the middle Albian sediment (Samples 545$43-2,130-140 \mathrm{~cm}$ ) contains a lower concentration of aromatic cyclopentanochrysene derivatives related to hopanoid precursors (Greiner et al., 1977) relative to the monoaromatic steroids. The alkyl thiophene $\left(\mathrm{M}^{+}=308\right)$ has a significant concentration only in Sample 545-34-1, 76-81 cm (Fig. 14A); this compound, together with other isomers and higher homologs, is quite common in immature deep-sea sediments (e.g., Rullkötter et al., 1981; Rullkötter, von der Dick, et al. 1982; Rullkötter, Mukhopadhyay, et al., in press) although the significance of the thiophenes is not clear yet. Another un- known aromatic hydrocarbon-particularly abundant in Sample 545-38-1, 65-80 cm (Fig. 14B) with a molecular ion at $\mathrm{m} / \mathrm{z} 414$, a base peak at $\mathrm{m} / \mathrm{z} 149$, and an additional fragment at $\mathrm{m} / \mathrm{z} 189$ as the only major peaks in the mass spectrum-also has been found, previously in deep-sea sediments from the Angola Basin (Rullkötter, Mukhopadhyay, et al., in press). In the Site 545 samples, this compound is accompanied by its lower homolog with all mass spectral peaks shifted to lower mass by 14 mass units. Perylene is a minor component in the aromatic hydrocarbon fractions of the Site 545 sediments.

Monoaromatic steroid hydrocarbons in the Site 545 sediments mainly consist of ring $\mathrm{A}$ and ring $\mathrm{B}$ aromatized compounds (Hussler et al., 1981; Hussler and Albrecht, 1983; Rullkötter and Welte, 1983), whereas the more stable C-ring aromatized isomers appear as trace components only in the deepest samples. Figure 15 shows mass chromatograms of the molecular ions and the key fragment $(\mathrm{m} / \mathrm{z} 211)$ of the monoaromatic steroid hydrocarbons for two selected samples. The traces indicate similar relative compositions, within the homologous series $\left(C_{27}\right.$ to $\left.C_{29}\right)$, comprising three different monoaromatic species each (cf. Table 6). As for the sterenes in the nonaromatic hydrocarbon fractions, the $\mathrm{C}_{27}$ and $\mathrm{C}_{29}$ monoaromatic steroids have higher concentrations than the $\mathrm{C}_{28}$ homologs. As a further correspondence to the nonaromatic hydrocarbons, there are monoaromatic steroid hydrocarbons with an additional double bond, probably at $\mathrm{C}-22$ in the sidechain, with the $\mathrm{C}_{28}$ compounds being predominant (Fig. 15C). 


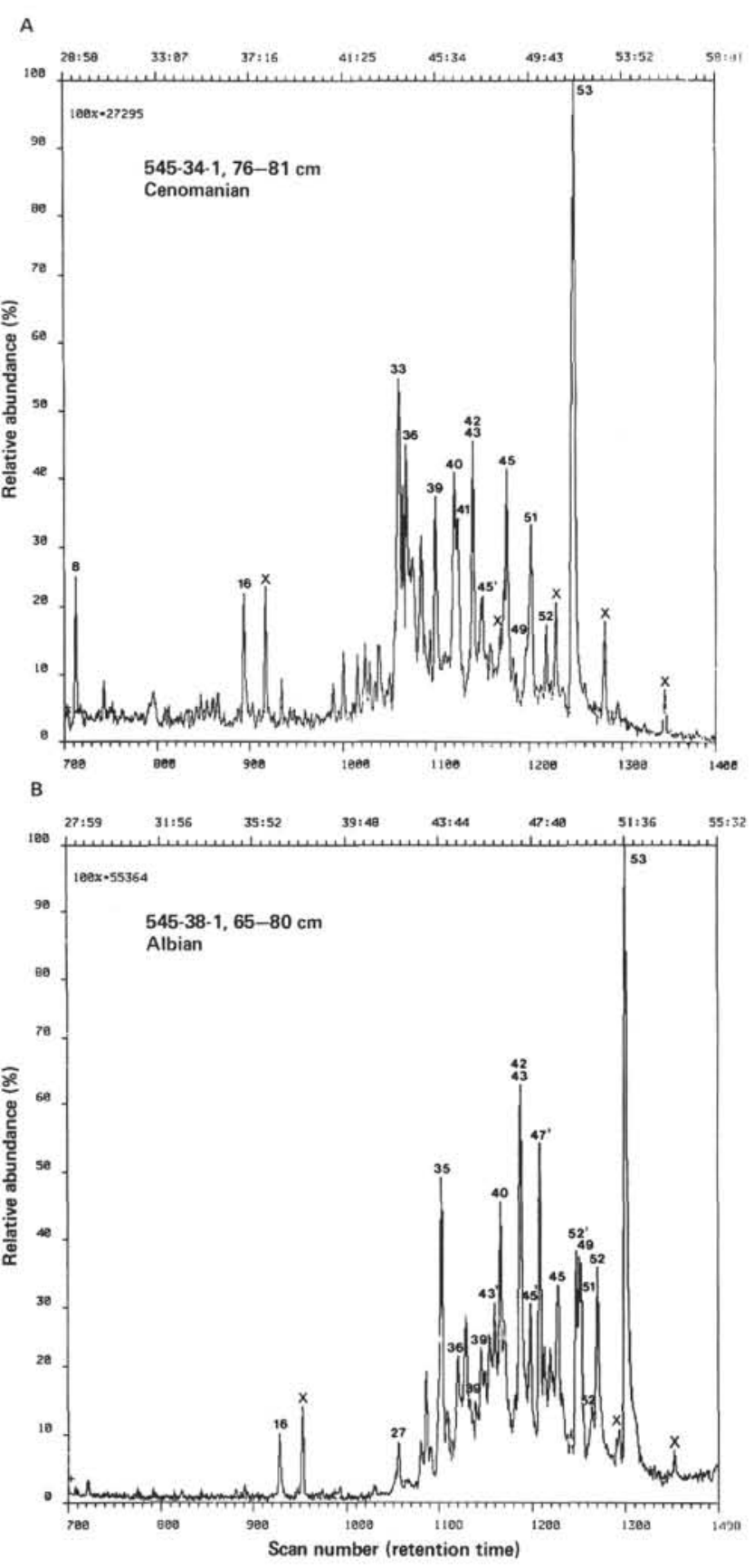

Figure 14. Partial total ion chromatograms from GC/MS analysis of the aromatic hydrocarbon fractions of two selected sediment samples from DSDP Site 545. Compare Table 6 for compound identification. Dashed numbers indicate monoaromatic steroid hydrocarbons with an additional double bond in the sidechain.

The Hole 547A and Hole 547B samples, with the exception of the Triassic sediment, principally show the same aromatic hydrocarbon characteristics as the Site 545 samples, except that the former have a higher proportion of unresolved aromatic hydrocarbons in the lower molecular weight range (scans 200 to 900 in Fig. 16) consisting of a complex mixture of isomeric and homologous alkylated species. In the higher molecular weight range monoaromatic steroid hydrocarbons and hopanoid- related aromatics dominate. Sample 547A-41-1, 30-48 cm (Cenomanian, Fig. 16B) contains a monoaromatic steroid hydrocarbon with a molecular ion at $\mathrm{m} / \mathrm{z} 352\left(\mathrm{C}_{26}\right)$ and key fragments shifted by 14 mass units indicating the loss of a methyl group during aromatization. $\mathrm{A} \mathrm{C}_{27}$ compound of this type has been found previously in a Miocene sediment from the outer California Continental Borderland (DSDP Site 467; Rullkötter and Welte, 1983). Benzohopanes occur in small concentrations in Sample 547A-66-2, 115-130 cm and the deeper Albian samples from Hole 547B.

The monoaromatic steroid hydrocarbon distributions for a late Eocene, two Cenomanian, and an Albian sample from Hole 547A are shown in Figure 17. Ring A and ring B monoaromatized steroids occur in significant amounts through the whole sequence down to the deepest Cretaceous samples, whereas ring $\mathrm{C}$ monoaromatic steroid hydrocarbons reach a concentration comparable to the ring $\mathrm{A}$ and ring $\mathrm{B}$ aromatized isomers only in Sample 547A-66-2, 115-130 cm (Albian; Fig. 17D). In the deeper Albian samples the $\mathrm{C}$-ring aromatic steroids dominate.

A completely different aromatic hydrocarbon distribution was found in the Triassic sediment from Section 547B-30-3 (Fig. 18). Most compounds identified (Table 6) are unsubstituted aromatics occasionally accompanied by their methyl and dimethyl homologs. Such a distribution is commonly related to a pyrolytic origin or coaly material (e.g., White and Lee, 1980). A reworked piece of coal was found in Core 547B-35 of the Triassic section (Mukhopadhyay et al., this volume).

\section{Diagenesis and Maturation}

Only four of the seven sediments investigated from Site 545 contained a sufficient quantity of primary vitrinites for reliable reflectance measurement. Recycled vitrinites, common in all samples, are the only vitrinite particles detected in Samples 545-26-1, 43-62 cm; 545$31-1,49-65 \mathrm{~cm}$; and $545-53-1,100-120 \mathrm{~cm}$. Thus, instead of vitrinite reflectance, we used spectral fluorescence parameters of sporinites to assess the maturity by conversion of the $\lambda_{\max }$ (maximum fluorescence intensity) and $Q$-values (red/green quotient) to vitrinite reflectance values (Teichmüller, 1982; Mukhopadhyay et al., 1983). The measured vitrinite reflectance values range from 0.26 to $0.30 \%$, whereas conversion of spectral fluorescence parameters yields a value of $0.20 \% R_{m}$ for the other three samples (Fig. 7). From both sets of data it is evident that the organic matter in the Site 545 sediments is of low maturity with little increase with depth down the hole.

The temperatures of maximum pyrolysis yield (Fig. 19), which are a combination of shipboard and shore-based data, only exhibit an increase within the Cenozoic section, but no significant gradient within the Cretaceous where the $\mathrm{T}_{\max }$ values remain close to $425^{\circ} \mathrm{C}$. A similar trend, that is, a rapid increase of $T_{\max }$ in very immature kerogens until a value of about $425^{\circ} \mathrm{C}$ is reached and then a slow increase with depth of burial until the onset of thermal hydrocarbon generation is reached was observed at the nearby DSDP Site 416 (Fig. 1) by Boute- 

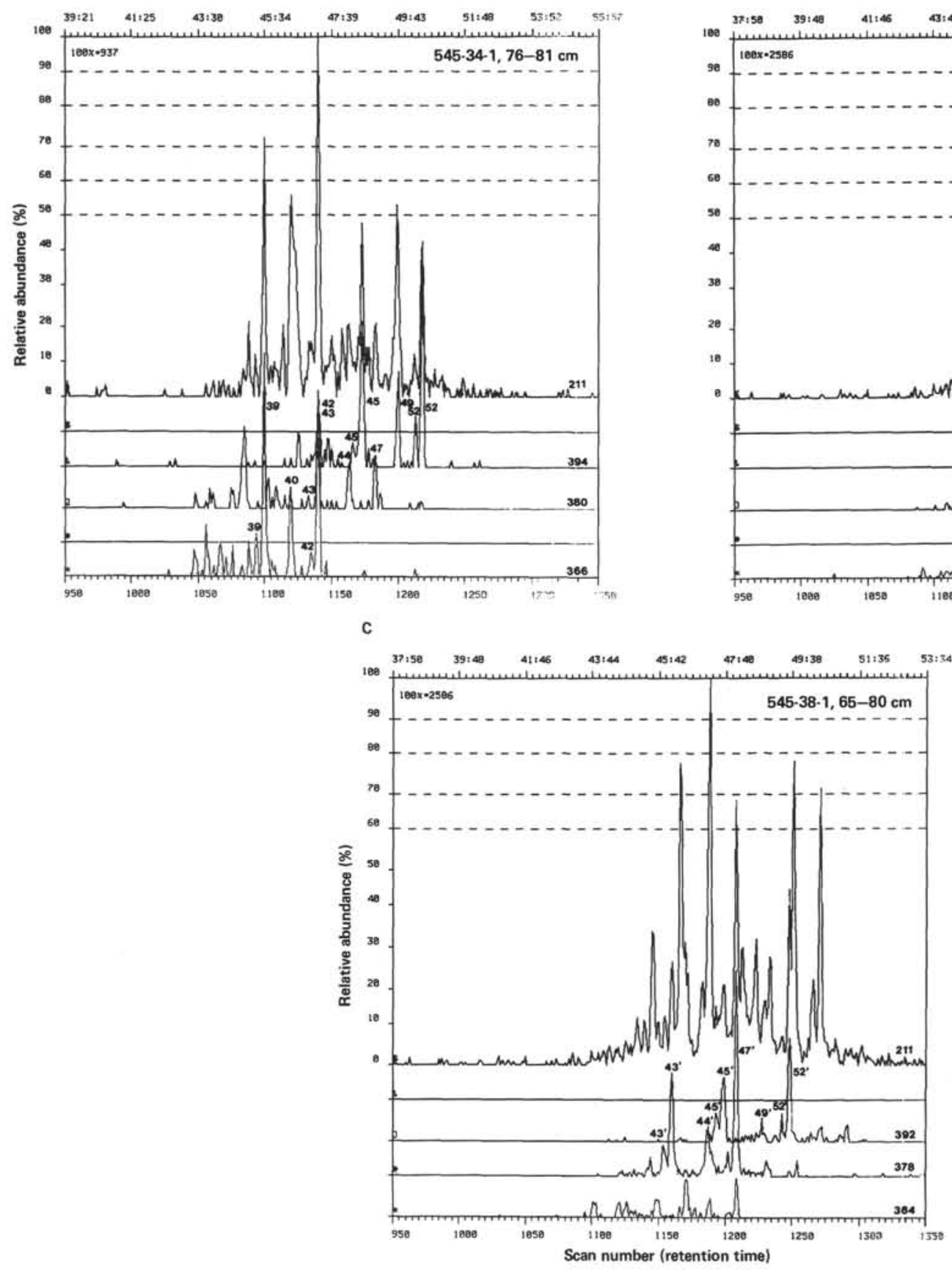

B

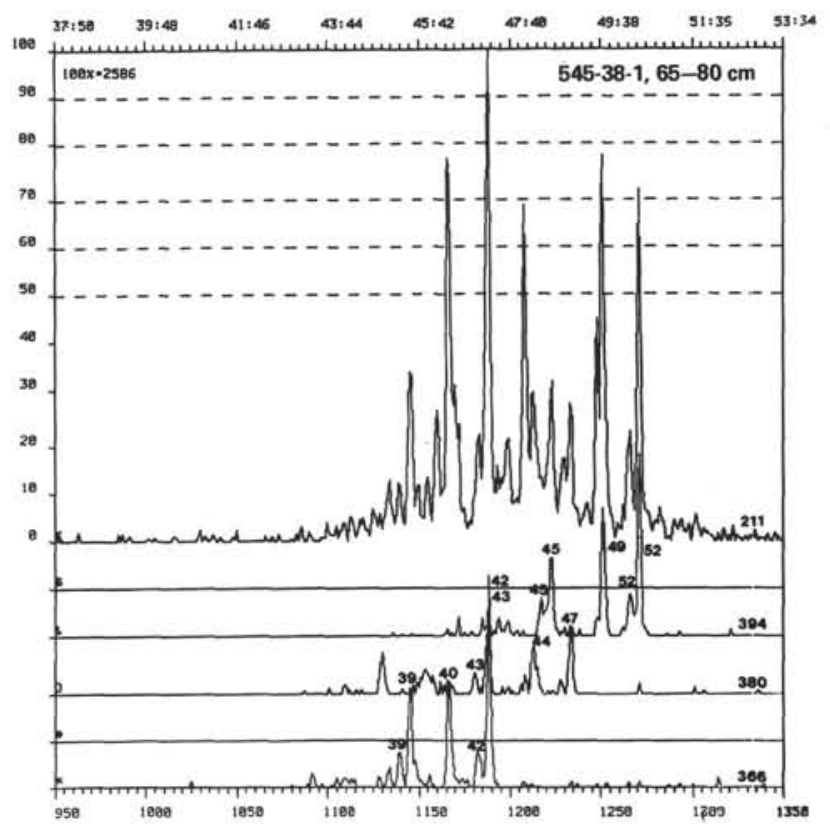

Figure 15. Mass chromatograms of the molecular ions and the key fragment $(\mathrm{m} / \mathrm{z} 211)$ of ring $\mathrm{A}$ and ring B monoaromatized steroid hydrocarbons $\left(\mathrm{C}_{27}-\mathrm{C}_{29}\right)$ without $(\mathrm{A}, \mathrm{B})$ and with $(\mathrm{C})$ an additional double bond in the sidechain (numbers with prime) for sediment samples from DSDP Site 545. Compare Table 6 for compound identification.

feu (1980). At that site, however, the $425^{\circ} \mathrm{C}$ level is reached at a sediment depth of about $900 \mathrm{~m}$, whereas this temperature already is reached around $300 \mathrm{~m}$ at Site 545 (Fig. 19). By assuming comparable geothermal conditions and keeping in mind that there is a Cretaceous/ Tertiary unconformity with the Cenomanian as the uppermost Cretaceous sediments at both sites, leads us to the possibility that up to $600 \mathrm{~m}$ more sediment were eroded at Site 545 than at Site 416 at the time the unconformity was formed.
The vitrinite reflectance values at Site 547 do not show a smooth trend with depth (Fig. 20). Most of the kerogens contain several vitrinite reflectance populations. Two major populations of recycled vitrinites (reflectance $0.75-1.10 \%$ and $1.20-1.65 \%$, respectively) were identified by their distinctive morphologic features like oxidation rims and bimacerite grains (Hagemann, 1974; Dow, 1977). The primary vitrinite populations are generally minor and amount between 5 and $20 \%$ of the total vitrinites. Although there is a distinct difference in matu- 
Table 6. Constituents of the aromatic hydrocarbon fractions of sediments from DSDP Holes 545, 547A, and 547B marked in Figures $13-18$.

\begin{tabular}{|c|c|c|}
\hline & Compound & Structure \\
\hline 1 & biphenyl & $x x$ \\
\hline 2 & dibenzofuran & $\mathrm{XXI}$ \\
\hline 3 & phenanthrene & $\mathrm{XXII}, \mathrm{R}=\mathrm{H}$ \\
\hline 4 & Unknown $(M+204)$ & \\
\hline 5 & $o$-terphenyl & XXIII \\
\hline 6 & methylphenanthrene & $\mathrm{XXII}, \mathrm{R}=\mathrm{CH}_{3}$ \\
\hline 7 & $\begin{array}{l}\text { dimethylphenanthrene } \\
\text { or ethylphenanthrene }\end{array}$ & $\mathrm{XXII}, \mathrm{R}=2 \mathrm{CH}_{3}$ or $\mathrm{C}_{2} \mathrm{H}_{5}$ \\
\hline 8 & alkylthiophene $\left(\mathrm{M}^{+} 308, \mathrm{BP} 111\right)$ & xxIV \\
\hline $8 \mathrm{a}$ & alkylthiophene $(\mathrm{M}+308, \mathrm{BP} 98)$ & $\mathrm{xxy}$ \\
\hline 9 & naphthobenzofuran & $X X V I, R=H$ \\
\hline 10 & p-terphenyl & XXvil \\
\hline 11 & methylnaphthobenzofuran & $\mathrm{XXVI}, \mathrm{R}=\mathrm{CH}_{3}$ \\
\hline 12 & $m$-terphenyl ? & XXVIII \\
\hline 13 & benzofluorene. & XXIX \\
\hline 14 & Unknown $\left(M^{+}\right.$242) & \\
\hline 15 & Unknown $\left(M^{+} 244\right)$ & \\
\hline 16 & pentamethyldodecahydrochrysene & $\mathrm{xxx}$ ? \\
\hline 17 & chrysene & XXXI \\
\hline 18 & Unknown $(M+258)$ & \\
\hline 19 & C-ring monoaromatic steroid: $5 \beta(\mathrm{H}), 20 \mathrm{~S}\left(\mathrm{C}_{27}\right)$ & $\mathrm{XXXII,R}=\mathrm{H}$ \\
\hline 20 & Unknown $\left(M^{+} 242\right)$ & \\
\hline 21 & Unknown $\left(\mathrm{M}_{+}^{+} 256\right)$ & \\
\hline 22 & Unknown $(M+254)$ & \\
\hline 23 & C-ring monoaromatic steroid: $5 \beta(\mathrm{H}), 20 \mathrm{R}\left(\mathrm{C}_{27}\right)$ & $\mathrm{XXXIII,R}=\mathrm{H}$ \\
\hline 24 & C-ring monoaromatic steroid: $5 \alpha(\mathrm{H}), 20 \mathrm{~S}\left(\mathrm{C}_{27}\right)$ & $X X X I V, R=H$ \\
\hline & $+5 \beta(\mathrm{H}), 20 \mathrm{~S}\left(\mathrm{C}_{28}\right)$ & $\mathrm{XXXII}, \mathrm{R}=\mathrm{CH}_{3}$ \\
\hline 25 & Unknown $(M+318)$ & \\
\hline 26 & C-ring monoaromatic steroid: $5 \alpha(\mathrm{H}), 20 \mathrm{R}\left(\mathrm{C}_{27}\right)$ & $X X X V, R=H$ \\
\hline & $+5 \alpha(\mathrm{H}), 20 \mathrm{~S}\left(\mathrm{C}_{28}\right)$ & $\mathrm{XXXIV,} \mathrm{R}=\mathrm{CH}_{3}$ \\
\hline & $+5 \beta(\mathrm{H}), 20 \mathrm{R}\left(\mathrm{C}_{28}\right)$ & $\mathrm{XXXIII,} \mathrm{R}=\mathrm{CH}_{3}$ \\
\hline & $+5 \beta(\mathrm{H}), 20 \mathrm{~S}\left(\mathrm{C}_{29}\right)$ & $\mathrm{XXXII,R}=\mathrm{C}_{2} \mathrm{H}_{5}$ \\
\hline 27 & Unknown $\left(\mathrm{M}^{+} 400,175, \mathrm{BP} 135\right)$ & \\
\hline 28 & C-ring monoaromatic steroid: $5 \alpha(\mathrm{H}), 20 \mathrm{~S}\left(\mathrm{C}_{29}\right)$ & $\mathrm{XXXIV}, \mathrm{R}=\mathrm{C}_{2} \mathrm{H}_{5}$ \\
\hline 29 & $\begin{array}{l}\mathrm{C} \text {-ring monoaromatic steroid: } 5 \alpha(\mathrm{H}), 20 \mathrm{R}\left(\mathrm{C}_{28}\right) \\
+5 \beta(\mathrm{H}), 20 \mathrm{R}\left(\mathrm{C}_{20}\right)\end{array}$ & $\mathrm{XXXV,R}=\mathrm{CH}_{3}$ \\
\hline 30 & Unknown (no $M^{+}$, BP 69$){ }^{+} S \beta(\mathrm{H}), 20 \mathrm{~K}\left(\mathrm{C}_{29}\right)$ & $\mathrm{Xxxm}, \mathrm{K}=\mathrm{C}_{2} \mathrm{H}_{5}$ \\
\hline 31 & benzo[elpyrene & XXXVI \\
\hline 32 & dinaphthobenzofuran & XXXVII \\
\hline 33 & $\mathrm{C}_{28}$ steradiene (incomplete MPLC separation) & \\
\hline 34 & 19-nor A-ring monoaromatic steroid $\left(C_{26}\right)$ & XXXVIII \\
\hline 35 & Unknown $(\mathrm{M}+414,185, \mathrm{BP} 149)$ & \\
\hline 36 & benzo[a]pyrene or perylene & $\mathrm{XXXIX} / \mathrm{XL}, \mathrm{R}=\mathrm{H}$ \\
\hline 37 & C-ring monoaromatic steroid: $5 \alpha(\mathrm{H}), 20 \mathrm{R}\left(\mathrm{C}_{29}\right)$ & $\mathrm{XXXV}, \mathrm{R}=\mathrm{C}_{2} \mathrm{H}_{5}$ \\
\hline 38 & methylbenzo[a]pyrene or -perylene & $\mathrm{XXXIX} / \mathrm{XL}, \mathrm{R}=\mathrm{CH}_{3}$ \\
\hline 39 & $\begin{array}{l}\text { B-ring monoaromatic } 14 \beta(\mathrm{H}) \text {-anthrasteroid } \\
\left(\mathrm{C}_{27}\right)\end{array}$ & $X L I, R=H$ \\
\hline 40 & A-ring monoaromatic steroid $\left(\mathrm{C}_{27}\right)$ & $\mathrm{XLII}, \mathrm{R}=\mathrm{H}$ \\
\hline 41 & ethylcyclopentanododecahydrochrysene & XLIII \\
\hline 42 & $\begin{array}{l}\text { B-ring monoaromatic } 14 \alpha(\mathrm{H}) \text {-anthrasteroid } \\
\left(\mathrm{C}_{27}\right)\end{array}$ & $\mathrm{XLIV}, \mathrm{R}=\mathrm{H}$ \\
\hline 43 & $\begin{array}{l}\text { B-ring monoaromatic } 14 \beta(\mathrm{H}) \text {-anthrasteroid } \\
\left(\mathrm{C}_{28}\right)\end{array}$ & $\mathrm{XLI}, \mathrm{R}=\mathrm{CH}_{3}$ \\
\hline 44 & A-ring monoaromatic steroid $\left(\mathrm{C}_{28}\right)$ & $\mathrm{XLII}, \mathrm{R}=\mathrm{CH}_{3}$ \\
\hline 45 & $\begin{array}{l}\text { B-ring monoaromatic } 14 \beta(\mathrm{H}) \text {-anthrasteroid } \\
\left(\mathrm{C}_{29}\right)\end{array}$ & $\mathrm{XLI}, \mathrm{R}=\mathrm{C}_{2} \mathrm{H}_{5}$ \\
\hline 46 & ethylcyclopentanooctahydrochrysene & $\mathrm{xLV}$ \\
\hline 47 & $\begin{array}{l}\text { B-ring monoaromatic } 14 \alpha(\mathrm{H}) \text {-anthrasteroid } \\
\left(\mathrm{C}_{28}\right)\end{array}$ & $\mathrm{XLIV}, \mathrm{R}=\mathrm{CH}_{3}$ \\
\hline 48 & Unknowns $(M+278, M \pm 294)$ & \\
\hline 49 & A-ring monoaromatic steroid $\left(C_{29}\right)$ & $\mathrm{XLII}, \mathrm{R}=\mathrm{C}_{2} \mathrm{H}_{5}$ \\
\hline 50 & benzoperylene or anthanthrene & XLVI/XLVII \\
\hline 51 & ethylcyclopentanotetrahydrochrysene & XLVIII \\
\hline 52 & $\begin{array}{l}\text { B-ring monoaromatic } 14 \alpha(\mathrm{H}) \text {-anthrasteroid } \\
\left(\mathrm{C}_{29}\right)\end{array}$ & $\mathrm{XLIV}, \mathrm{R}=\mathrm{C}_{2} \mathrm{H}_{5}$ \\
\hline 53 & ethylcyclopentanochrysene & IL \\
\hline 54 & Unknowns $\left(\mathrm{M}^{+}+308, \mathrm{M}^{+} .290\right)$ & \\
\hline 55 & Unknown $\left(\mathrm{M}^{+}: 304\right)$ & \\
\hline 56 & benzohopanes & $\mathrm{L}, \mathrm{R}=\mathrm{H} \ldots \mathrm{C}_{3} \mathrm{H}_{7}$ \\
\hline 57 & $\begin{array}{l}\text { Unknown monoaromatic steroid ? (M! } \\
4118,197,158)\end{array}$ & \\
\hline 58 & Unknowns $(\mathrm{M}+316, \mathrm{M} \div 290)$ & \\
\hline 59 & Unknown $\left(\mathrm{M}^{+}+444\right)$ & \\
\hline 60 & Unknown $\left(\mathrm{M}^{+} 324, \mathrm{BP} 295\right)$ & \\
\hline 61 & Unknown $\left(\mathrm{M}^{+} 490,433,419,181,167, \mathrm{BP} 111\right)$ & \\
\hline $\mathrm{x}$ & Contaminant (e.g., phthalates, column bleed) & \\
\hline
\end{tabular}

Note: Identifications are tentative from mass spectra and relative retention times. Compounds are listed in approximate order of elution from the GC column. Compare appendix for compound structures. $\mathrm{M}^{+}=$molecular ion; $\mathrm{BP}=$ base peak. rity, as expressed by vitrinite reflectance, between the shallowest $\left(0.31 \% \mathrm{R}_{\mathrm{m}}\right)$ and the deepest sample $(0.54 \%$ $R_{m}$ ), both the Cretaceous and Jurassic sections show much scatter with two samples having unusually low reflectance values. Bitumen impregnation, a common cause for low reflectance values, cannot be assumed for the low values of Samples 547B-6-1, 77-84 cm (Albian) and 547B-15-2, 8-12 cm (Early Jurassic), because they did not yield elevated total extract amounts. Spectral fluorescence measurements of the Jurassic samples both by the wave length of the highest fluorescence intensity $\left(\lambda_{\max }\right)$ and the ratio of the fluorescence intensity at 650 and $500 \mathrm{~nm}$ ( $Q$-value) indicate two populations of liptinites (mainly sporinite) within each sample showing different $\lambda_{\max }$ and $Q$-values. The lower $\lambda_{\max }$ and $Q$-values in each case are regarded as representing primary sporinites, whereas the higher ones are attributed to recycled sporinites. This is consistent with two populations of vitrinites observed by reflectance measurement of the kerogens from the Jurassic black shale samples.

The plot of temperatures of maximum pyrolysis yield versus depth (Fig. 21) confirm the difficulties in establishing a maturation gradient for the organic matter in the Site 547 sediments. This difficulty at least partly reflects the common downslope transport events at this site. Within the Cenozoic the $\mathrm{T}_{\max }$ values rapidly increase to about $430^{\circ} \mathrm{C}$, the higher values (above $420^{\circ} \mathrm{C}$ ) being in the Eocene and Paleocene sections containing frequent slumps of Cretaceous material. The upper part of the mid-Cretaceous section shows significant scatter of $\mathrm{T}_{\max }$ values, but most data points appear to concentrate around a value of $420^{\circ} \mathrm{C}$, that is, considerably lower than in the Eocene and Late Cretaceous sediments above. From about $600 \mathrm{~m}$ downward there is an increase of $\mathrm{T}_{\max }$ values up to $430^{\circ} \mathrm{C}$ with a decrease again at the base of the Cretaceous. In the Jurassic, the temperature data scatter between 415 and $435^{\circ} \mathrm{C}$, which makes it impossible to reliably assess the maturity. Finally, the organic matter in the Triassic sediments appears to have a significantly higher maturity than that in the younger sediments.

The abundance of olefinic hydrocarbons even in the deepest Cretaceous samples from Site 545 also indicate that the organic matter is still immature at a depth of about $500 \mathrm{~m}$. Consequently, the diagenetic changes in the molecular composition of the extractable hydrocarbons are only small. Noticeable is the occurrence of phytenes in the Cenomanian and the late Albian sediments and the disappearance of these compounds, probably due to diagenetic hydrogenation, at greater depth. Similarly, there appears to be a slight increase of the sterane/sterene + sterane ratio with depth as calculated based on the abundance of their mass spectrometric key fragments (see Rullkötter and Welte, 1983). In the Cenomanian and Albian sediments, the $\mathrm{C}_{27}$ sterane concentration is about $20 \%$, whereas values of 39 and $35 \%$ were measured for the late Aptian sediments. Still, these values indicate immaturity and reflect the low geothermal heat flow at the Northwest African Continental Margin. For comparison, about $40 \%$ steranes were detected at $1250 \mathrm{~m}$ depth in early Miocene sediments of 

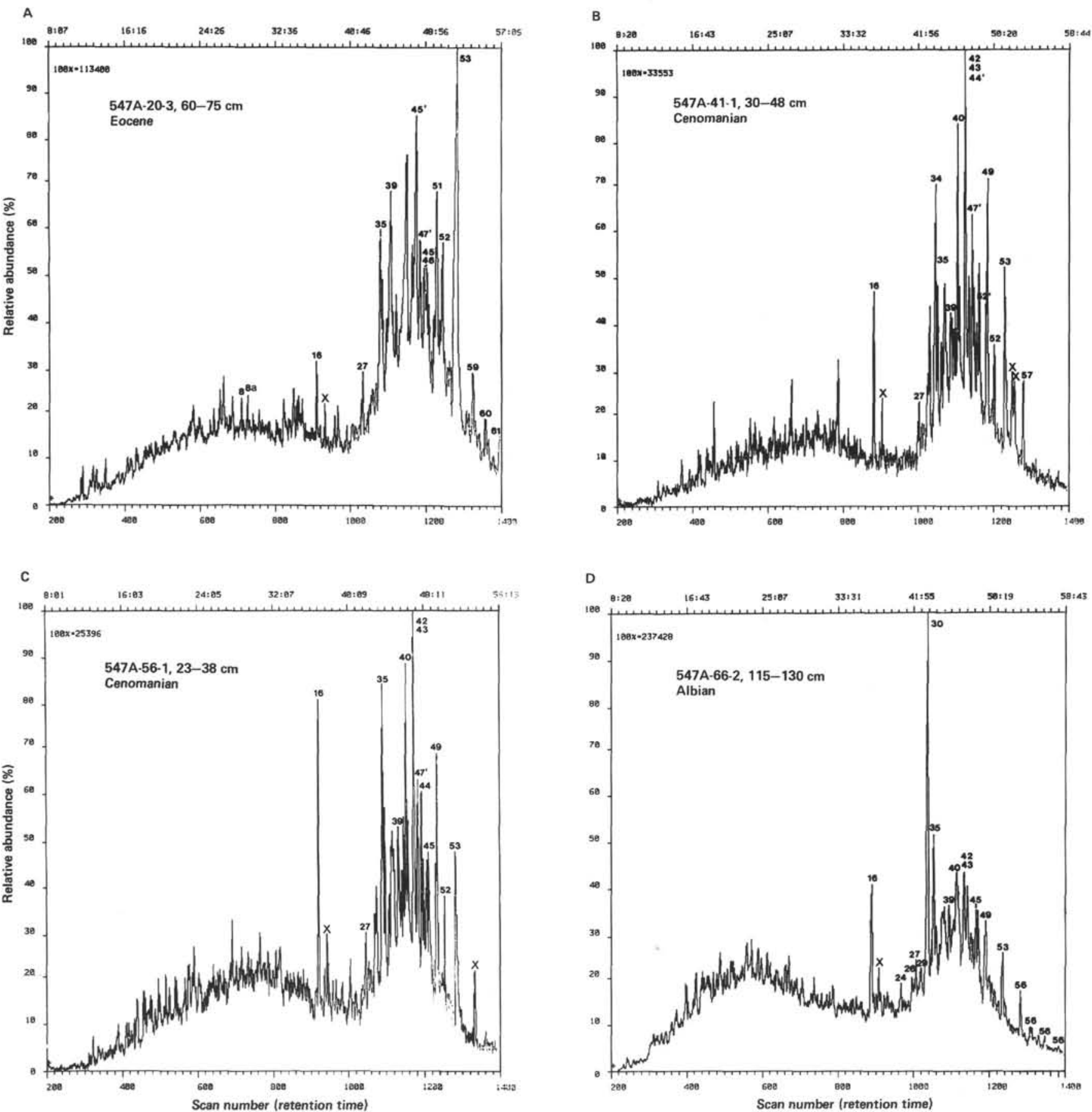

Figure 16. Partial total ion chromatograms from GC/MS analysis of the aromatic hydrocarbon fractions of selected sediment samples from DSDP Hole 547A. Compare Table 6 for compound identification. Numbers with prime indicate monoaromatic steroid hydrocarbons with an additional double bond in the side chain.

DSDP Hole 397A south of the Canary Islands, whereas middle Miocene sediments at about $600 \mathrm{~m}$ depth in the high heat flow area off Baja California (Site 471) contain nearly $100 \%$ steranes (Rullkötter and Welte, 1983).

The sediments from Site 547 have diagenetic characteristics on the molecular level similar to those from Site 545 , although phytenes were only detected in the late
Eocene slump sediment from Section 547A-20-3. Down to the base of the Cretaceous, olefinic hydrocarbons in the nonaromatic hydrocarbon fractions have significant concentrations. The $\mathrm{C}_{27}$ sterane concentration is $41 \%$ of total regular $\mathrm{C}_{27}$ steranes and sterenes in Sample 547B-6-1, $77-84 \mathrm{~cm}$ (i.e., slightly higher than in the deepest Cretaceous sample at Site 545). This slightly higher maturation level is confirmed by the occurrence of diasterenes 

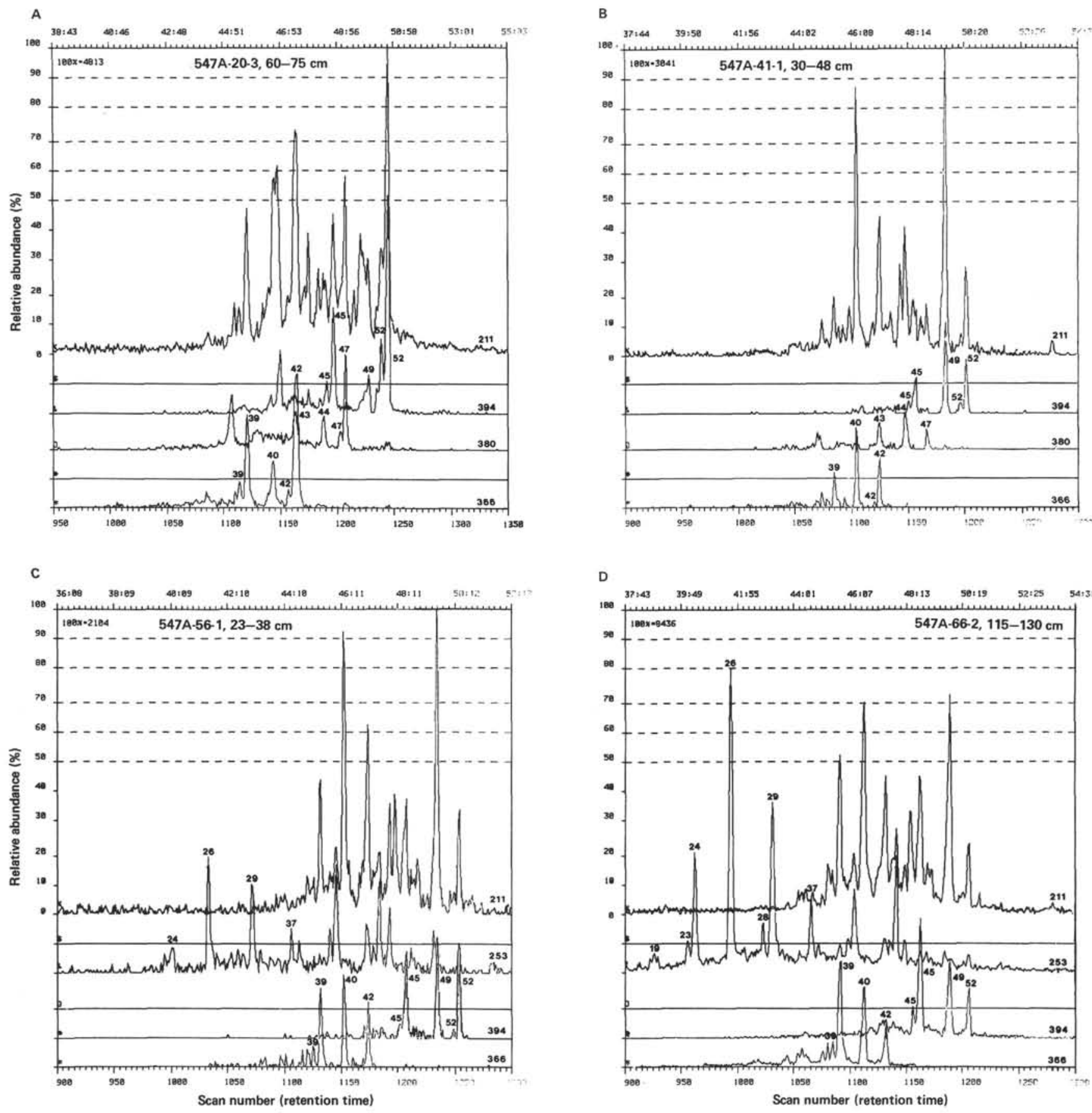

Figure 17. Mass chromatograms of the molecular ions $(\mathrm{m} / \mathrm{z} 366,380,394)$ and key fragments $(\mathrm{m} / \mathrm{z} 211,253)$ of monoaromatic steroid hydrocarbons in the aromatic hydrocarbon fractions of selected sediment samples from DSDP Hole 547A. Compare Table 6 for compound identification.

at the $770 \mathrm{~m}$ depth level in Hole 547B and the dominance of C-ring aromatic steroid hydrocarbons over their ring $\mathrm{A}$ and ring $\mathrm{B}$ aromatized isomers.

The Triassic sediment is definitely more mature than the Cretaceous samples. This is clearly seen from the $n$-alkane distribution, although the difference in organofacies type does not allow a further comparison using the polycyclic biological marker hydrocarbons. Based on the $n$-alkane distribution and the temperature of maximum pyrolysis yield, the maturity of the Triassic sediment would be expected to be even higher than expressed by the measured vitrinite reflectance. It cannot clearly be determined, however, to what extent reworked organic matter has an influence on the maturity data of this sample.

\section{INTERPRETATION}

\section{Organofacies}

Deposition of the probable Triassic sediment at DSDP Site 547 seaward of the present Mazagan Plateau may have occurred in a continental environment before the 


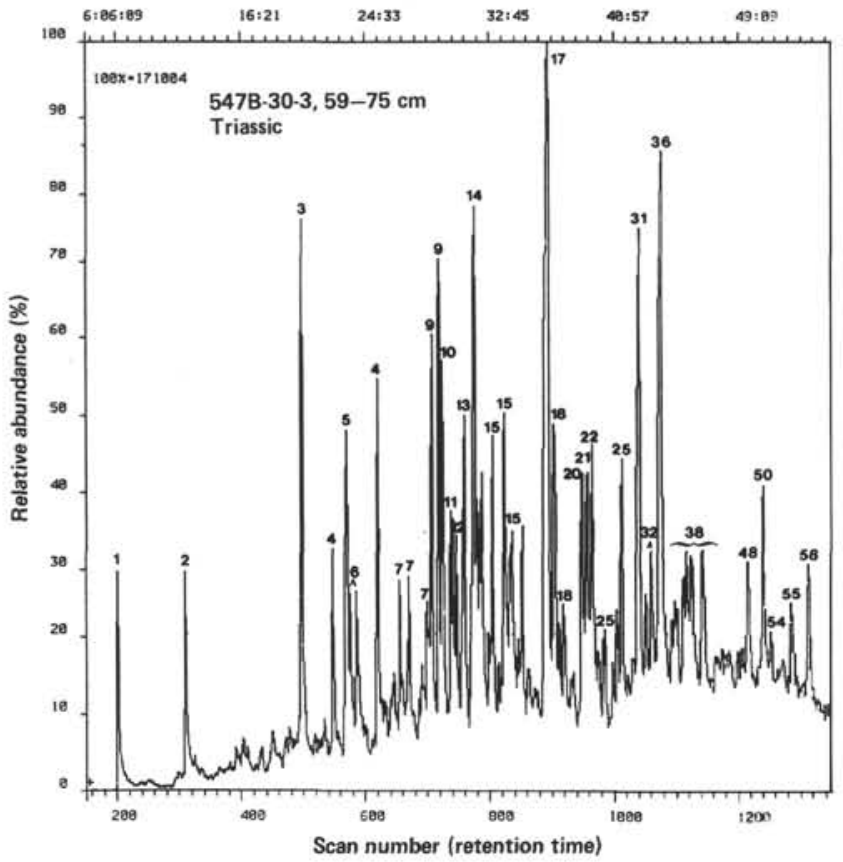

Figure 18. Partial total ion chromatogram from GC/MS analysis of the aromatic hydrocarbon fraction of a Triassic sediment sample from DSDP Hole 547B. Compare Table 6 for compound identification.

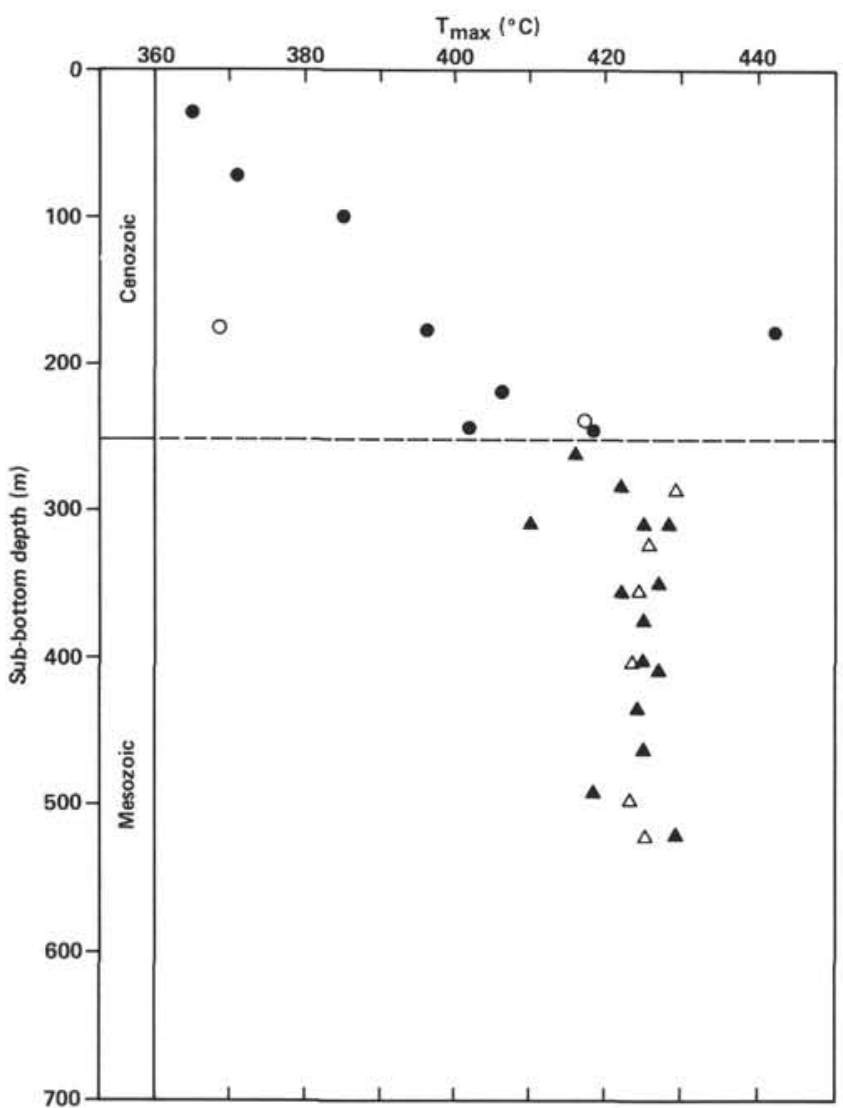

Figure 19. Temperatures of maximum pyrolysis yield $\left(\mathrm{T}_{\max }\right.$ from RockEval pyrolysis) versus depth for DSDP Site 545 sediments. Closed symbols indicate shipboard data, open symbols are from shorebased studies.

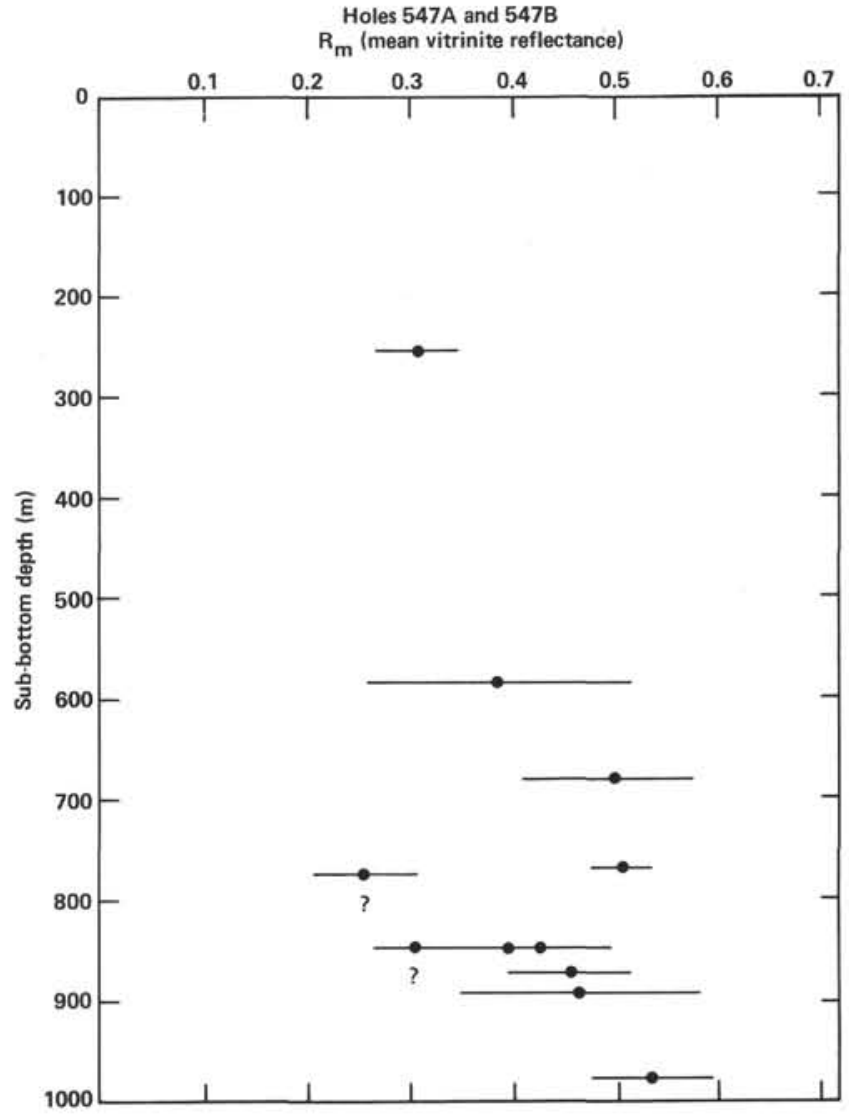

Figure 20. Vitrinite reflectance versus depth for DSDP Site 547 sediments.

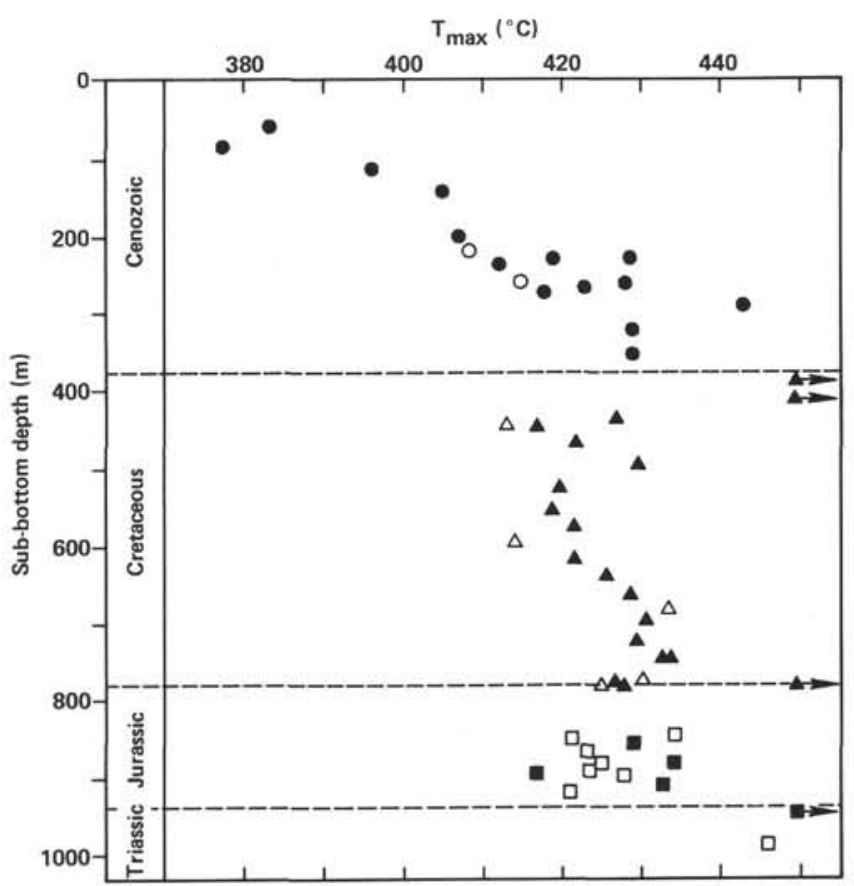

Figure 21. Temperatures of maximum pyrolysis yield $\left(\mathrm{T}_{\max }\right.$ from RockEval pyrolysis) versus depth for DSDP Site 547 sediments. Closed symbols indicate shipboard data, open symbols are from shorebased studies. Arrows indicate values in excess of $450^{\circ} \mathrm{C}$. 
opening of the Atlantic Ocean. Only terrigenous organic matter was detected microscopically by maceral analysis (Fig. 8). The $n$-alkane distribution indicates the presence of terrigenous organic matter of post-diagenetic maturity (Fig. 11I), and the aromatic hydrocarbon composition (Fig. 18) points to a pyrolytic (forest fire?) source or, more likely, to a coaly type of organic matter. The frequent alternation of red and gray sandy mudstones in the Triassic interval in Hole 547B and the low organic carbon content of the samples investigated (Fig. 4) indicate that the depositional environment was oxic in general, but that oxygen-depleted conditions were occasionally reached within the sediment by destruction of a major proportion of the originally supplied organic matter.

Starting with the Jurassic section, deposition occurred in a deep-water environment that generally is unfavorable for the preservation of organic matter. Unusual in this respect is the presence of thin organic-matter-rich black shales in the Jurassic interval at Site 547. Gradational increase of organic matter content from the micritic limestone matrix into the black shales together with decreasing bioturbation suggest autochthonous deposition of the black shales in a progressively anoxic environment rather than downslope transport events as in the younger sections at this site. High concentrations of terrigenous organic matter in the Jurassic black shales indicate that the oxygen depletion was caused by a periodically increasing land-derived supply of organic matter rather than stagnant anoxic water conditions. Where this effect was strong, considerable amounts of lipid material was preserved (Samples 547B-15-2, 8-12 cm; 547B-20-2, 92-104 cm). In other cases, mainly residual organic matter was left behind when sufficient oxygen was available for near-complete oxidation (e.g., Samples 547B-15-2, 14-17 cm; 547B-18-1, 100-117 cm).

The Cretaceous on the Mazagan Escarpment is restricted to a late Aptian through Cenomanian sedimentary sequence at Site 545 and to mainly Albian through Cenomanian sediments, with a thin organic-carbon-lean Early Cretaceous section on top of the Jurassic and a Late Cretaceous debris flow section at the seaward Site 547. The Cretaceous green nannofossil claystones at Site 545 show abundant slump folds and microfaults and are cut by low-angle slide surfaces that may result in repetition of stratigraphic sections (site chapter, Site 545, this volume). Redeposition phenomena are even more pronounced in the Cretaceous sections of Holes 547A and 547B, where grayish green nannofossil-bearing claystones and mudstones were encountered with common intraformational flat-pebble mudstone conglomerate layers, slump structures, and repeated sections suggesting slide sheets (site chapter, Site 547 this volume). Because recognizable slump clasts have slightly higher organic carbon contents than the surrounding matrix and because there is no principal difference in organic matter type between these two sediment types, it has to be assumed that much of the organic matter in the midCretaceous sediments on the Mazagan Escarpment has been transported down the continental slope and redeposited at the continental rise in a graben-type basin bordered by the Jurassic carbonate platform of the Mazagan Plateau to the southeast and a rotated basement high to the northwest (Fig. 2). Abundant organic matter supply from a nearby continental source initially may have led to deposition on the outer shelf, leading to anoxic conditions in the sediment and good preservation of a major part of the terrigenous lipid material. Apparently, these conditions also allowed a certain amount of marine organic matter to be accumulated and preserved; this preservation may have been supported by coastal upwelling connected with high bioproductivity and oxygen depletion in the water column. These sediments then were transported down the slope and redeposited on the continental rise as described previously. Rapid burial allowed much of the organic matter to be preserved even when the bottom water was oxic. The uniformity of the organic matter content and composition especially in the Albian/Cenomanian at Site 547 and of the lithology throughout the Cretaceous at both sites may, however, indicate that land-derived organic matter supply was so massive that some of it directly reached the deep ocean environment in a more dispersed form as a constant flow down the slope.

During the Cenozoic, which is limited to post-Oligocene sediments at Site 545 and an additional complex debris flow interval dated Campanian to Eocene but with a major proportion of redeposited Cretaceous material at Site 547, hemipelagic or pelagic deep-water sedimentation prevailed on the Mazagan Escarpment. Organic matter preservation is mainly restricted to residual terrigenous organic matter oxidized during subaerial transport and/or settling through an oxic water column. Terrigenous organic matter supply to the Moroccan Continental Margin in the Mazagan area apparently had diminished at least by early Miocene times. The only organic-matter-rich zone within the Cenozoic sediments is the Eocene slump sequence penetrated in Hole 547A. There is paleontological (site chapter, Site 547 this volume) and organic geochemical evidence (occurrence of the same series of rare $C_{28}$ triterpenes in the Eocene slump and a Cenomanian sediment) that a major part of the sediment material is of mid- to Late Cretaceous age. The presence of more than $50 \%$ marine organic matter in the sample investigated (Fig. 8) can be explained by initial deposition in shallower water on the outer shelf in an oxygen-depleted environment caused by high terrigenous organic matter supply and possibly the effects of coastal upwelling (cf. Rullkötter, Vuchev, et al., 1983), as discussed previously for the Cretaceous sediments.

Microbial action on the organic matter in the sediment from the Mazagan Escarpment was obvious from the presence of significant amounts of amorphous organic matter in many samples and by the abundant occurrence of hopanoid hydrocarbons in the extractable organic matter. There was no indication, however, that this microbial activity led to a considerable reduction in hydrogen content as recently found in sediments of DSDP Leg 76 in the Blake-Bahama Basin (Rullkötter et al., unpublished data). There, massive microbial reworking also of predominantly terrigenous organic matter in Cre- 
taceous sediments led to the abundant formation of micrinite particles (inert residues of formerly hydrogenrich liptinitic organic matter) and a strong overall hydrogen depletion of the total organic matter.

\section{Comparison of Sites 545 and 547 and Relation to Other Drill Sites on the Northwest African Continental Margin}

DSDP Site 547 is located approximately $15 \mathrm{~km}$ north of Site 545 on the southwest-northeast-striking Northwest African Continental Margin off Morocco. From the projection onto the seismic line $\mathrm{A}-\mathrm{A}^{1}$ in Figure 2, Site 545 is offset about $1 \mathrm{~km}$ to the southwest (out of the projection plane), and Site 547 is about $5 \mathrm{~km}$ to the northeast (cf. fig. 2 of Hinz et al., 1982). Within this narrow area sedimentation of organic matter apparently was governed by dominant processes resulting in very similar organofacies types in the Cretaceous and Cenozoic sediments at Sites 545 and 547. The Paleogene section penetrated at Site 547 is missing at Site 545 located further up the continental rise. Most of the Jurassic limestone and dolomite at Site 545 appeared strongly oxidized and thus was not investigated further for organic matter content. Similarly, the nodular limestone sequence at Site 547 is organic-matter-poor. Owing to the complex geological development of the Jurassic ocean margin that needs further studies on the sediment material recovered during DSDP Leg 79, it is not possible at the moment to delineate a more detailed picture of the depositional environment for the black shales encountered in Hole 547B and to argue about their absence (if within the stratigraphic interval drilled) at Site 545 .

The organic geochemical results obtained for the DSDP Leg 79 samples compare well with previous observations made on sediment of comparable stratigraphic age from the Northwest African Continental Margin (see Cornford et al., 1980, and Rullkötter, Cornford, et al., 1982, for summaries). The organic-matter-lean post-Oligocene sediments from the Mazagan Escarpment correspond to those hemipelagic Miocene and post-Miocene sediment at DSDP Site 397 south of the Canary Islands also containing only residual terrigenous organic matter (e.g., Cornford et al., 1979) and to most of the Tertiary sediments from DSDP Site 415 in the Agadir Canyon and Site 416 in the Morocco Basin (Boutefeu, 1980; Cornford, 1980; Galimov et al., 1980). Organic-matter-rich sediments derived from downslope redeposition within the Tertiary, similar to the Eocene slump interval at Site 547 , are known from the early and middle Miocene at Site 397 south of the Canary Islands (e.g., Cornford et al., 1979). The outer shelf and upper slope was determined as the source of the transported material that ranged in age from Cretaceous to slightly older than the autochthonous matrix (Arthur and von Rad, 1979).

During the Cretaceous, terrigenous organic matter has influenced the sediments along the entire Northwest African Continental Margin as far as could be determined by the results of deep-sea drilling. At Site 397; the only Cretaceous section recovered comprises Hauterivian sediment containing about $0.5 \%$ organic carbon; the or- ganic matter was of purely terrigenous origin and its preservation was fair (Cornford et al., 1979). During DSDP Leg 50 (Sites 415 and 416; Fig. 1), a more complete Cretaceous section was drilled. Tithonian to Albian sediments at Site 416 (Fig. 1) were mostly turbidites, in which the organic matter, as in the Leg 79 Cretaceous sediments, mainly reflects the depositional environment at the source of the transported material. Organic carbon values were mostly below $1 \%$ at Site 416 (Boutefeu, 1980 ). Kerogen microscopy revealed the presence of marine organic matter especially in the more organic-carbon-rich sediments that apparently were initially deposited under oxygen-minimum conditions (Cornford, 1980). The extractable hydrocarbons contain abundant longchain wax alkanes of terrigenous origin in all Cretaceous sediments from Site 416 (Claypool and Baysinger, 1980). The upper Albian to mid/Upper Cretaceous sediments at Site 415 in the Agadir Canyon also show common microfolds, slump structures, fractures, and an organofacies similar to that found in the sediments from Sites 416,545 , and 547, although the organic carbon contents at Site 415 (Boutefeu, 1980) seem to be lower on the average than they are in the Mazagan Escarpment sediments.

\section{Hydrocarbon Generation Potential}

A summary of the hydrocarbon generation potential of the different sediments from the Mazagan Escarpment has been given previously based on shipboard results (Rullkötter, Vuchev, et al., in press). The good coincidence of shipboard and shore-based organic geochemical results provides supporting evidence for the preliminary conclusions. Briefly, a moderate to good petroleum potential, depending on the degree of lipid-rich marine organic matter preserved, can be ascribed to the Eocene slump sediments and all of the Cretaceous sediments in which the terrigenous liptinitic material is also well preserved. The Jurassic black shales have only a fair hydrocarbon potential if regarded as a whole; the top layer by itself principally has a higher potential although it is too thin at Site 547 to gain any significant importance. The autochthonous Cenozoic sediments and the rest of the Jurassic as well as the Triassic sediments have virtually no hydrocarbon potential.

All of the sediments with a significant hydrocarbon potential at Sites 545 and 547 are thermally immature, however, at the burial depth they were found. They are slightly more deeply buried in the center of the grabentype basin between the Mazagan Escarpment and the basement block at Site 544 (Fig. 2), but still this burial may not be sufficient for thermal hydrocarbon generation. Seismic stratigraphy of the sediments seaward of the basement block at Site 544 indicates that the same sediments encountered at Sites 545 and 547 extend further offshore and are buried to a depth of several kilometers (K. Hinz, personal communication, 1981). It has to be considered, however, that there may be a change of organofacies in this more distal area caused by a reduced rate of organic matter preservation leading to a reduction of the hydrocarbon potential. 


\section{ACKNOWLEDGMENTS}

We would like to thank Dr. M. Radke and Dr. J. Gormly for extraction/liquid chromatography and Rock-Eval/organic carbon measurements, respectively. Technical assistance by U. Disko, Mrs. B. Kammer, F. J. Keller, F. Leistner, H. Pooch, J. Schnitzler, H. Willsch, and Mrs. B. Winden is gratefully acknowledged. The manuscript was typed by Mrs. A. Köntges. J. R. is grateful to the Deutsche Forschungsgemeinschaft (DFG), Bonn, and the National Science Foundation, Washington, for the chance to participate in DSDP Leg 79 as shipboard organic geochemist. We acknowledge financial support of this work by the Deutsche Forschungsgemeinschaft, Bonn, Grant No. We 346/25. We are indebted to Dr. Simon Brassell, University of Bristol, and Dr. Keith Kvenvolden, U.S. Geological Survey (Menlo Park), for thorough reviews of the manuscript.

\section{REFERENCES}

Arthur, M. A., and von Rad, U., 1979. Early Neogene base-of-slope sediment at Site 397, DSDP Leg 47a: sequential evolution of gravitative mass transport processes and redeposition along the Northwest African passive margin. In Lancelot, Y., Winterer, E. L., et al., Init. Repts. DSDP, 50: Washington (U.S. Govt. Printing Office), 603-639.

Blumer, M., Guillard, R. R. L., and Chase, T., 1971. Hydrocarbons of marine phytoplankton. Mar. Biol., 8:183-189.

Bostick, N., 1979. Microscopic measurement of the level of catagenesis of solid organic matter in sedimentary rocks to aid exploration for petroleum and to determine former burial temperatures-a review. SEPM Special Publ., 26:17-43.

Boutefeu, A., 1980. Pyrolysis study of organic matter from Deep Sea Drilling Projects Sites 370 (Leg 41), 415, and 416 (Leg 50). In Lancelot, Y., Winterer, E. L., et al., Init. Repts. DSDP, 50: Washington (U.S. Govt. Printing Office), 555-566.

Brassell, S. C., Comet, P. A., Eglinton, G., Isaacson, P. J., McEvoy, J., Maxwell, J. R., Thomson, I. D., Tibbetts, P. J. C., and Volkman, J. K., 1980. The origin and fate of lipids in the Japan Trench. In Douglas, A. G., Maxwell, J. R. (Eds.), Advances in Organic Geochemistry-1979: Oxford (Pergamon Press), pp. 375-392.

Brassell, S. C., Wardroper, A. M. K., Thomson, I. D., Maxwell, J. R., and Eglinton, G., 1981. Specific acyclic isoprenoids as biological markers of methanogenic bacteria in marine sediments. Nature 290:693-696.

Claypool, G. E., and Baysinger, J. P., 1980. Analysis of organic matter in sediment cores from the Moroccan Basin, Deep Sea Drilling Project Sites 415 and 416. In Lancelot, Y., Winterer, E. L., et al., Init. Repts. DSDP, 50: Washington (U.S. Govt. Printing Office), 605-608.

Comet, P. A., McEvoy, J., Brassell, S. C., Eglinton, G., Maxwell, J. R., and Thomson, I. D., 1981. In Thiede, J., Vallier, T., et al., Init. Repts. DSDP, 62: Washington (U.S. Govt. Printing Office), 923-937.

Cornford, C., 1980. Petrology of organic matter, Deep Sea Drilling Project Site 415 and 416, Moroccan Basin, eastern North Atlantic. In Lancelot, Y., Winterer, E. L., et al., Init. Repts. DSDP, 50: Washington (U.S. Govt. Printing Office), 609-614.

Cornford, C., Rullkötter, J., and Welte, D. H., 1979. Organic geochemistry of DSDP Leg 47A, Site 397, eastern North Atlantic: organic petrography and extractable hydrocarbons. In von Rad, U., Ryan, W. B. F., et al., Init. Repts. DSDP, 47, Pt. 1: Washington (U.S. Govt. Printing Office), 511-522.

1980. A synthesis of organic petrographic and geochemical results from DSDP sites in the eastern central North Atlantic. In Douglas, A. G., and Maxwell, J. R. (Eds.), Advances in Organic Geochemistry-1979: Oxford (Pergamon Press), pp. 445-453.

Didyk, B. M., Simoneit, B. R. T., Brassell, S. C., and Eglinton, G., 1978. Organic geochemical indicators of paleoenvironmental conditions of sedimentation. Nature 272:216-222.

Dow, W., 1977. Kerogen studies and geological interpretation. J. Geochem. Explor., 7:79-99.

Eglinton, G., and Hamilton, R. J., 1963. The distribution of alkanes. In Swain, T. (Ed.), Chemical Plant Taxonomy: London (Academic Press), pp. 187-217.

Espitalié, J., Laporte, J. L., Madec, M., Marquis, F., Leplat, P., Paulet, J., and Boutefeu, A., 1977. Méthode rapide de caractérisation des roches-meres, de leur potentiel pétrolier et de leur degré d'évolution. Rev. Inst. Fr. Petrol., 32:23-42.

Galimov, E. M., Chinyonov, V. A., and Ivanov, Ye. N., 1980. Isotopic composition of methane carbon and the relative content of gaseous hydrocarbons in the deposits of the Moroccan Basin of the Atlantic ocean (Deep Sea Drilling Project Sites 415 and 416). In Lancelot, Y., Winterer, E. L., et al., Init. Repts. DSDP, 50: Washington (U.S. Govt. Printing Office), 615-622.

Gormly, J., and Mukhopadhyay, P. K., 1983. Hydrocarbon potential of kerogen types by pyrolysis-gas chromatography. In Bjorøy, M., et al. (Eds.), Advances in Organic Geochemistry-1981: Chichester (Wiley), pp. 597-606.

Greiner, A. C., Spyckerelle, C., Albrecht, P., and Ourisson, G., 1977. Hydrocarbures aromatiques d'origine géologique. V.-Dérivés monoet di-aromatiques du hopane. J. Chem. Res., (M):3829-3869.

Hagemann, H. W., 1974. Petrographische and palynologische Untersuchung der organischen Substanz (Kerogen) in den liassischen Sedimenten Luxemburgs. In Tissot, B., and Bienner, F. (Eds.), Advances in Organic Geochemistry-1973: Paris (Editions Technip), pp. 29-37.

Hinz, K., Winterer, E. L., Baumgartner, P. O., Bradshaw, M. J., Channel, J. E. T., Jaffrezo, M., Jansa, L. F., Leckie, R. M., Moore, J. N., Rullkötter J., Schaftenaar, C., Steiger, T. H., Vuchev, V., and Wiegand, G. E., 1982. Preliminary results from DSDP Leg 79 seaward of the Mazagan Plateau off Morocco. In von Rad, U., Hinz, K., Sarnthein, M., and Seibold, E. (Eds.), Geology of the Northwest African Continental Margin: Berlin-Heidelberg (Springer-Verlag), pp. 23-33.

Huang, W. Y., and Meinschein, W. G., 1979. Sterols as ecological indicators. Geochim. Cosmochim. Acta, 43:739-745.

Hussler, G., and Albrecht, P., 1983. $\mathrm{C}_{27}-\mathrm{C}_{29}$ Monoaromatic anthrasteroid hydrocarbons in Cretaceous black shales. Nature, 304: 262-263.

Hussler, G., Chappe, B., Wehrung, P., and Albrecht, P., 1981. $C_{27}$ $\mathrm{C}_{29}$ ring A monoaromatic steroids in Cretaceous black shales. $\mathrm{Na}$ ture, 294:556-558.

Mukhopadhyay, P. K., Rullkötter, J., and Welte, D. H., 1983. Facies and diagenesis of organic matter in sediments from the Brazil Basin and the Rio Grande Rise, Deep Sea Drilling Project Leg 72. In Barker, P., Johnson, D., et al., Init. Repts. DSDP, 72: Washington (U.S. Govt. Printing Office), 821-828.

Ourisson, G., Albrecht, P., and Rohmer, M., 1979. The hopanoids. Paleochemistry and biochemistry of a group of natural products. Pure Appl. Chem., 51:709-729.

Radke, M., Sittardt, H. G., and Welte, D. H., 1978. Removal of soluble organic matter from rock samples with a flow-through extraction cell. Anal. Chem., 50:663-665.

Radke, M., Willsch, H., and Welte, D. H., 1980. Preparative hydrocarbon group type determination by automated medium pressure liquid chromatography. Anal. Chem., 52:406-411.

Roucaché, J., Deroo, G., and Boulet, R., 1979. Caractérisation par différentes méthodes physico-chimiques de types de matière organique dans des sédiments du Crétacé d'Atlantique en mer profonde. Rev. Inst. Fr. Petrol., 34:191-220.

Rullkötter, J., Cornford, C., and Welte, D. H., 1982. Geochemistry and petrography of organic matter in Northwest African continental margin sediments: quantity, provenance, depositional environment and temperature history. In von Rad, U., Hinz, K., Sarnthein, M., and Seibold, E. (Eds.), Geology of the Northwest African Continental Margin: Berlin, Heidelberg, New York (Springer-Verlag), 686-703.

Rullkötter, J., Leythaeuser, D., and Wendisch, D., 1982. Novel 23,28bisnorlupanes in Tertiary sediments.-Widespread occurrence of nuclear demethylated triterpanes. Geochim. Cosmochim. Acta, 46: 2501-2509.

Rullkötter, J., Mukhopadhyay, P. K. and Welte, D. H., in press. Geochemistry and petrography of organic matter in sediments from Holes 530A, Angola Basin, and Hole 532, Walvis Ridge, Deep Sea Drilling Project. In Hay, W. W., Sibuet, J.-C., et al., Init. Repts. $D S D P, 75$ : Washington (U.S. Govt. Printing Office).

Rullkötter, J., von der Dick, H., and Welte, D. H., 1981. Organic petrography and extractable hydrocarbons of sediments from the eastern North Pacific Ocean, Deep Sea Drilling Project Leg 63. In Yeats, R. S., Haq, B. U., et al., Init. Repts. DSDP, 63: Washington (U.S. Govt. Printing Office), 819-836. 
1982. Organic petrography and extractable hydrocarbons of sediments from the Gulf of California, Deep Sea Drilling Project Leg 64, In Curray, J. R., Moore, D. G., et al., Init. Repts. DSDP, 64: Pt. 2: Washington (U.S. Govt. Printing Office), 837-853. Rullkötter, J. Vuchev, V., Hinz, K., Winterer, E. L., Baumgartner, P. O., Bradshaw, M. L., Channell, J. E. T., Jaffrezo, M., Janza, L. F., Leckie, R. M., Moore, J. M., Schaftenaar, C., Steiger, T. H., and Wiegand, G. E., 1983. Potential deep sea petroleum source beds related to coastal upwelling. In Thiede, J., and Suess, E. (Eds.), Coastal Upwelling: Its Sedimentary Record: New York (Plenum Publ. Corp.), Part B, pp. 467-483.

Rullkötter, J., and Welte, D. H., 1983. Maturation of organic matter in areas of high heat flow: a study of sediments from DSDP Leg 63, offshore California, and Leg 64, Gulf of California. In Bjorøy, M., et al. (Eds.), Advances in Organic Geochemistry-1981: Chichester (Wiley), pp. 438-448.

Seifert, W. K., and Moldowan, J. M., 1980. The effect of thermal stress on source rock quality as measured by hopane stereochemistry. In Douglas, A. G., and Maxwell, J. R. (Eds.), Advances in Organic Geochemistry-1979: Oxford (Pergamon Press), pp. 229-237.

Simoneit, B. R. T., Mazurek, M. A., Brenner, S., Crisp, P. T., and Kaplan, I. R., 1979. Organic geochemistry of Recent sediments from Guaymas Basin, Gulf of California. Deep-Sea Res., 26A:879-891.
Stach, E., Mackowsky, M. T., Teichmüller, M., Taylor, G. H., Chandra, D., and Teichmüller, R., 1982. Coal Petrology: Berlin, Stuttgart, (Gebrüder Bornträger).

Teichmüller, M., 1982. Fluoreszenzmikroskopische Änderungen von Liptiniten und Vitriniten mit zunehmendem Inkohlungsgrad und ihre Beziehungen zu Bitumenbildung und Verkokungsverhalten: Krefeld (Geologisches Landesamt Nordrhein-Westfalen).

Teichmüller, M., and Ottenjann, K., 1977. Art und Diagenese von Liptiniten und lipoiden Stoffen in einem Erdölmuttergestein aufgrund fluoreszenzmikroskopischer Untersuchungen. Erdöl, Kohle Petrochem., 30:387-398.

Tissot, B., Durand, B., Espitalié, J., and Combaz, A., 1974. Influence of the nature and diagenesis of organic matter in formation of petroleum. Am. Assoc. Petrol. Geol. Bull., 58:499-506.

White, C. M., and Lee, M. L., 1980. Identification and geochemical significance of some aromatic components of coal. Geochim. Cosmochim. Acta, 44:1825-1832.

Date of Initial Receipt: August 11, 1983

Date of Acceptance: February 2, 1984 

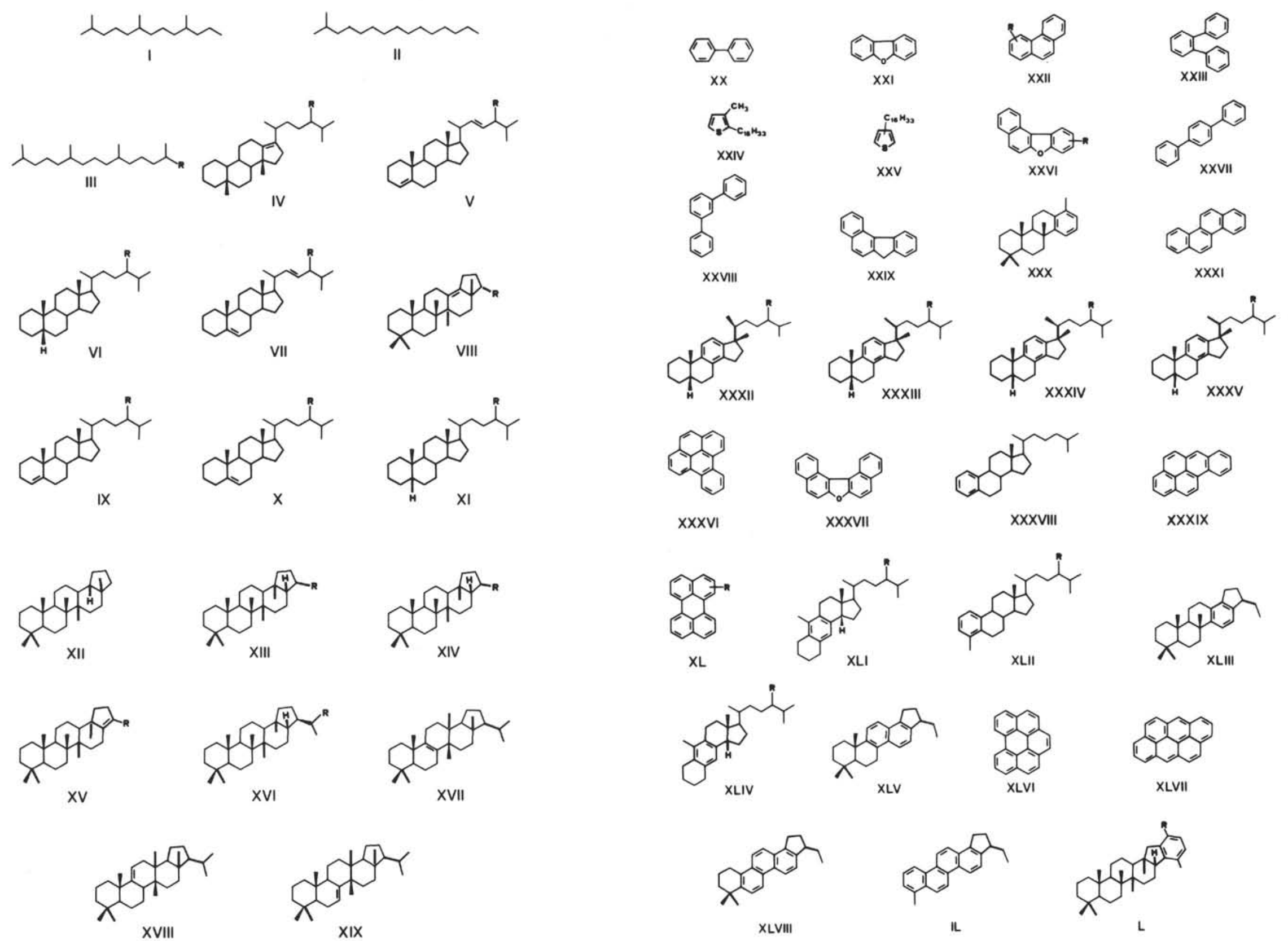

XL
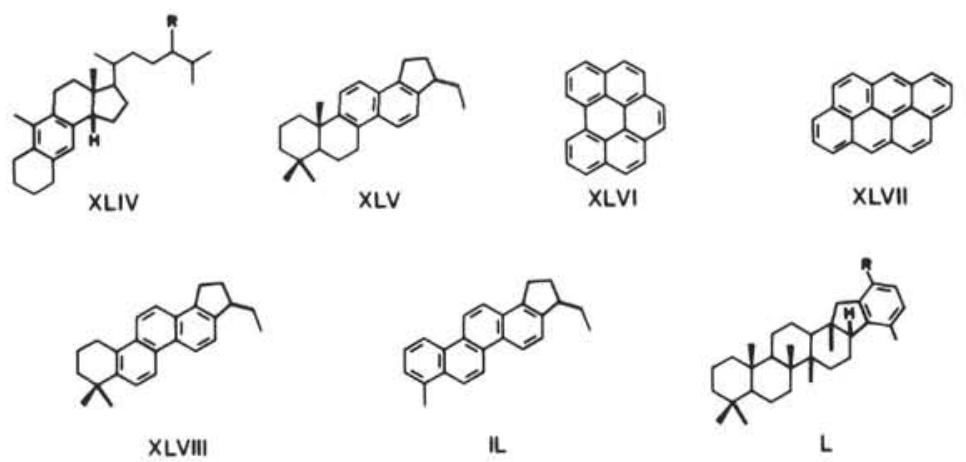

XLVIII
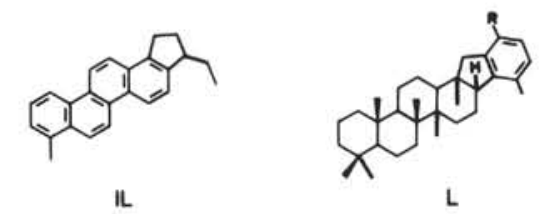